EGG-WMD--10244-App. A

DE92 019852

\title{
Mixed and Low-Level Waste Treatment Facility Project
}

\section{Appendix A-Environmental and Regulatory Planning and Documentation}

(Draft)

Published April 1992

Idaho National Engineering Laboratory

EG\&G Idaho, Inc.

Idaho Falls, Idaho 83415

Prepared for the

U.S. Department of Energy

Office of Environmental Restoration and Waste Management

Under DOE Idaho Fleld Offica

Ciontract DE-AC07-761D01570
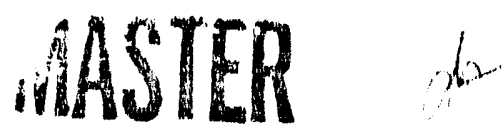


\section{CONTENTS}

ACRONYMS $\ldots \ldots \ldots \ldots \ldots \ldots \ldots \ldots \ldots \ldots \ldots \ldots \ldots \ldots \ldots \ldots \ldots \ldots \ldots \ldots$

1. INTRODUCTION $\ldots \ldots \ldots \ldots \ldots \ldots \ldots \ldots \ldots \ldots \ldots \ldots \ldots \ldots \ldots$

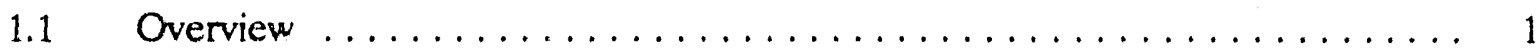

2. FEDERAL STATUTES, REGULATIONS, EXECUTIVE ORDERS, AND DOE

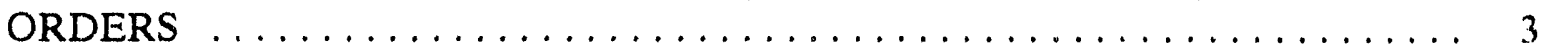

2.1 Atomic Energy Act of 1954, as Amended (42 U.S.C. 2011 et seq.) . . . . . 3

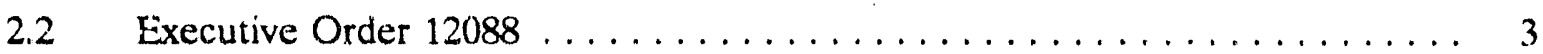

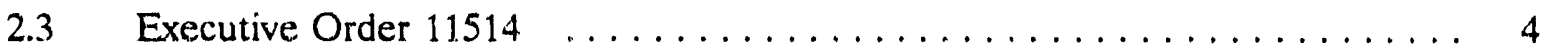

2.4 National Environmental Policy Act (42 U.S.C. $4321-4347) \ldots \ldots \ldots \ldots \ldots .4$

2.4 .1 Preoperational $\mathrm{N}_{\mathrm{s} \text { onitoring }} \ldots \ldots \ldots \ldots \ldots \ldots \ldots \ldots \ldots$

2.5 DOE Order 5480.4, Environmental Protection, Safety, and Health Protection

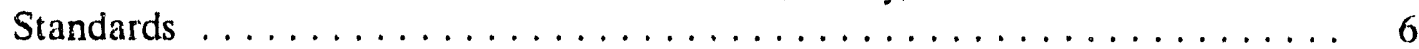

2.6 National Historic Preservation Act $\ldots \ldots \ldots \ldots \ldots \ldots \ldots \ldots \ldots \ldots \ldots$

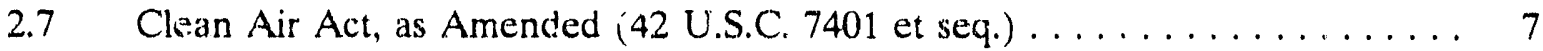

2.7.1 40 CFR 50, National Ambient Air Quality Standards ........... 8

2.7.2 40 CFR 60 Standards of Performance for New Stationary Sources .... 9

2.7.3 40 CFR 61, National Emission Standards for Hazardous Air Pollutants ......................... 9

2.8 Clean Water Act, as Amended (33 U.S.C. 1251 et seq.) $\ldots \ldots \ldots \ldots \ldots \ldots 12$

2.8.1 National Pollutant Discharge Elimination System (NPDES)

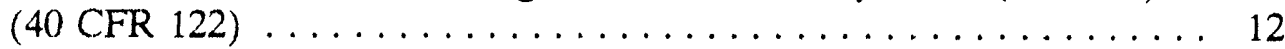

2.9 Safe Drinking Water Act, as Amended [42 U.S.C. 300 (f) et seq.] . . . . . 13

2.10 Executive Orders 11988 and $11990 \ldots \ldots \ldots \ldots \ldots \ldots \ldots \ldots \ldots$

2.11 Endangered Species Act, as Amended (16 U.S.C. 1531 et seq.) . . . . . . . . 14

2.11.1 Fish and Wildlife Coordination Act (16 U.S.C. $661-666 \mathrm{C}) \ldots \ldots \ldots 15$

2.12 Migratory Bird Treaty Act, as Amended (16 U.S.C. 703 et seq.) . . . . . . . 15

2.13 Bald and Golden Eagle Protection Act, as Amended (16 U.S.C. 6683-668d) .. 15 
2.14 Noise Control Act of 1972, as Amended (42 U.S.C. 4901 et seq.) . . . . . . 16

2.15 Resource Conservation and Recovery Act, as Amended

(42 U.S.C. 6901 et seq.) . . . . . . . . . . . . . . . . . . . . . . . 16

2.16 DOE Order 5820.2A, Radioactive Waste Management $\ldots \ldots \ldots \ldots \ldots \ldots 16$

2.17 DOE Order 5400.3, Hazardous and Radioactive Mixed Waste Program . . .. 17

2.18 Land Disposal of Solid Waste $\ldots \ldots \ldots \ldots \ldots \ldots \ldots \ldots \ldots \ldots \ldots \ldots$

2.19 Nonhazardous Wastewater Treatment (Except Land Application) . . . . . . 17

2.20 Nonhazardous Wastewater Treatment by Land Application . . . . . . . . . 18

2.21 Toxic Substance Control Act of $1976 \ldots \ldots \ldots \ldots \ldots \ldots \ldots$

3. STATE OF IDAHO REGULATIONS AND GUIDELINES $\ldots \ldots \ldots \ldots \ldots \ldots$

3.1 Idaho Environmental Protection and Health Act $\ldots \ldots \ldots \ldots \ldots \ldots \ldots$

3.2 Idaho Air Pollution Control Regulations $\ldots \ldots \ldots \ldots \ldots \ldots \ldots \ldots \ldots$

3.2.1 Idaho Permit To Construct/Prevention of Significant Deterioration . . 21

3.3 Idaho Water Quality Standards and Wastewater Treatment Requirements . . 25

3.3.1 Production Water Wells ..................... 25

3.3.2 Idaho Regulations for Public Drinking Water Systems . . . . . . . . 26

3.4 Idaho Solid Waste Management $\ldots \ldots \ldots \ldots \ldots \ldots \ldots \ldots \ldots \ldots$

3.4.1 Land Disposal of Solid Waste . . . . . . . . . . . . . . . 29

3.5 Idaho Hazardous Waste Management . . . . . . . . . . . . . . . . . 29

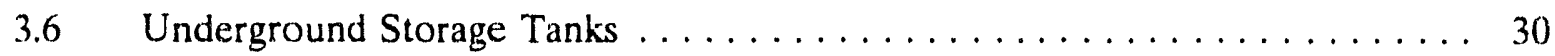

Attachment $1-$ INEL MLLWTF Permitting and Approval Summary $\ldots \ldots \ldots \ldots \ldots$

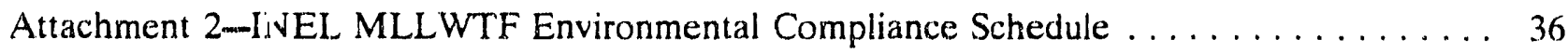




\section{ACRONYMS}

AEA

ALARA

BACT

BLM

CAA

CEQ

CFR

CWA

DEQ

DOE

DOE-ID

EDE

EIS

EO

EPA

EPD

FWS

FR.

HMB

IAQB

IDAPA

IDHW

INEL

MLLWTF
Atomic Energy Act

as low as reasonably achievable

best available control technology

U.S. Bureau of Land Management

Clean Air Act

Council on Environmental Quality

Code of Federal Regulations

Clean Water Act

Division of Environmental Quality

Department of Energy

U.S. Department of Energy-Idaho Field Office

effective dose equivalent

environmental impact statement

executive order

Environmental Protection Agency

Environmental Protection Division (DOE-ID)

U.S. Fish and Wildlife Service

Federal Register

Hazardous Materials Bureau

Idaho Air Quality Bureau

Idaho Administrative Procedures Act

Idaho Department of Health and Welfare

Idaho National Engineering Laboratory

Mixed and Low-Level Waste Treatment Facility 


\begin{tabular}{|c|c|}
\hline NAAQS & National Ambient Air Quality Standards \\
\hline NEPA & National Environmental Policy Act \\
\hline NESHAP & National Emission Standards for Hazardous Air Pollutants \\
\hline NPDES & National Pollution Discharge Elimination System \\
\hline NRC & Nuclear Regulatory Commission \\
\hline NSPS & New Source Performance Standards \\
\hline $\mathrm{PCB}$ & polychlorinated biphenyl \\
\hline PE & professional engineer \\
\hline PSD & prevention of significant deterioration \\
\hline PTC & permit to construct \\
\hline RCRA & Resource Conservation and Recovery Act \\
\hline SHPO & State Historical Preservation Office \\
\hline SIP & state implementation plan \\
\hline TSCA & Toxic Substances Control Act \\
\hline TSDF & treatment, storage, and disposal facility \\
\hline UST & underground storage tank \\
\hline WAC & waste acceptance criteria \\
\hline
\end{tabular}




\section{Mixed and Low-Level Waste Treatment Facility Project}

\section{Appendix A-Environmental and Regulatory Planning and Documentation}

\section{FOREWORD}

Section 1 of this Appendix contains the INEL Mixed and Low-Level Waste Treatment Facility Environmental Compliance Plan and Schedule, January 1992. This report compiles a survey of the primary Federal, State of Idaho, and DOE environmental protection regulations and standards applicable to the siting, construction, and operation of the proposed MLLWTF. Included in this plan is a table summarizing applicable permits and a timeline for integration of regulatory compliance documentation with design, construction, and operation phases of the MLLWTF project.

Section 2 contains the National Environmental Policy Act Requirements and Options for the Mixed and Low-Level Waste Treatment Facility, November 1991. This report outlines the NEPA requirements and options for the proposed MLLWTF. It includes a discussion of the federal statutes, regulations, executive orders, and DOE orders implementing NiPA as well as the documentation, and processes, required for NEPA compliance during design phases of the proposed facility.

Section 3 contains Regulatory Justification for the Treatment of Mixed and Low-Level Waste at the Idaho National Engineering Laboratory, November 1991. This report identifies authorities, regulatory requirements, and reasons for treatment of mixed and low-level waste streams.

Section 4 contains the Preliminary Siting Requirements for the Proposed Mixed and Low-Level Waste Treatment Facility at the Idaho National Engineering Laboratory, EGG-WM-10155, March 1992. This report contains applicable siting requirements for the MLLWTF identified from EPA regulations and DOE orders, that will be developed into siting criteria used to identify alternative locations for the proposed facility.

Section 5 contains, Health and Safety Criteria Overview for the Mixed and Low-Level Waste Treatment Facility at the Idaho National Engineering Laboratory, March 1992. This report identifies general health and safety considerations for the MLLWTF, and describes the plans for a detailed health and safety study to be completed in the future. 


\section{INEL Mixed and Low.Level Waste Treatment Facility Environmental Compliance Plan and Schedule}

M. J. Jorgenson Waters

Published March 1992

Idaho National Engineering Laboratory

EG\&G Idaho, Inc. Idaho Falls, Idaho 83415 


\section{INEL Mixed and Low-Level Waste Treatment Facility Environmental Compliance Plan and Schedule}

\section{INTRODUCTION}

An important part of the Department of Energy Idaho Field Office (DOE-ID) waste management mission is to identify, evaluate, develop, and use technologies designed to minimize and/or dispose of hazardous, radioactive, and mixed waste, and for remediation and restoration of previous disposal sites in an effort to protect human health and the environment. Inherent in this mission is the development and implementation of treatment technologies to reduce the toxicity, mobility, and volume of the various contaminants in the waste generated and stored at the Idaho National Engineering Laboratory (INEL).

Currently, $33 \%$ of the low-level waste volume generated at the INEL is disposed in an untreated waste form. This waste represents over $99 \%$ of the total curie content of the low-level waste inventory. Presently, no capability exists at the INEL to treat this portion of the waste.

DOE-ID proposes to site, construct, and operate a mixed and low-level waste treatment facility (MLLWTF) at the INEL. The facility is intended to treat/process and package waste contaminated with hazardous constituents and/or low-level beta-gamma radionuclides to meet disposal site waste acceptance criteria in accordance with Environmental Protection Agency (EPA), State, and Department of Energy (DOE) regulations.

Associated facilities for the MLLWTF include a proposed mixed and low-level waste disposal facility (MLLWDIF) and an administrative support facility, which would contain offices for support functions related to the facility. Environmental compliance issues for the MLLWDF are to be addressed within a separate project.

\subsection{Overview}

This environmental compliance plan and schedule compiles a survey of the primary Federal, State of Idaho, and DOE environmental protection regulations and standards applicable to the siting, construction, and operation of the MLLWTF. The compilation will facilitate environmental compliance planning required for successful fulfillment of the MLLWTF mission. This INEL MLLWTF environmental compliance plan and schedule is meant to be a living document and will be updated as the project evolves.

The complexities of the combination of Federal, State, and DOE requirements have been clarified by dividing this plan into three sections: (1) Introduction; (2) Fecleral Statues, Regulations, 
Executive Orders, and DOE Orders; and (3) State of Idaho Regulations and Guidelines. Sections 2 and 3 are divided into the guidance that the MLLWTF must follow. The applicability of the guidance is a predesign judgement and, therefore, conservative. This plan includes a supplemental table that summarizes the permits and approvals applicable to the MLLWTF project (Attachment 1) and a timeline for integration of regulatory compliance documentation with design, construction, and operation phases of the MLLWTF project (Attachment 2). 


\section{FEDERAL STATUTES, REGULATIONS, EXECUTIVE ORDERS, AND DOE ORDERS}

Projects at the INEL must comply with the applicable environmental Federal statutes, regulations, executive orders (EO), DOE orders, and guidelines that provide for protection of public health and the environment.

\subsection{Atomic Energy Act of 1954, as Amended (42 U.S.C. 2011 et seq.)}

Authority: $\quad 42$ U.S.C. 2011 et seq.

The Atomic Energy Act of 1954 (AEA) authorized DOE to establish standards to protect health or minimize dangers to life or property. DOE is exempt from Nuclear Regulatory Commission (NRC) regulations except as specified in Section 202 of the Energy Reorganization Act of 1974 (i.e., DOE facilities that accept commercial high-level waste are licensed by the NRC). DOE has established an extensive system of standards and requirements through its orders to ensure safe operation of its facilities. Compliance with these orders is mandatory for Federal facility managing and operating contractors, such as EG\&G Idaho.

\subsection{Executive Order 12088}

Authority: President

EO 12088 [Federal Compliance with Pollution Control Standards (October 13, 1978), as amended by EO 12580 (January 23, 1987)] requires Federal agencies to comply with applicable administrative and procedural pollution control standards established by, but not limited to, the following Federal laws:

- Toxic Substances Control Act (15 U.S.C. 2061 et seq.)

- Federal Water Pollution Control Act, as amended (33 U.S.C. 1251 et seq.)

- Public Health Service Act, as amended by the Safe Drinking Water Act (42 U.S.C. $300 \mathrm{~F}$ et seq.)

- Clean Air Act, as amended (42 U.S.C. 7401 et seq.)

- $\quad$ Noise Control Act of 1972 (42 U.S.C. 4901 et seq.)

- Solid Waste Disposal Act, as amended (42 U.S.C. 6901 et seq.). 


\subsection{Executive Order 11514}

Authority: President

EO 11514, as amended by EO 11991, requires Federal agencies to monitor and control their activities on a continuing basis to protect and enhance the quality of the environment. In addition, Federal agencies are to develop procedures to ensure the fullest practicable provision of timely public information and understanding of Federal plans and programs that may result in environmental impacts in order to obtain the views of interested parties. EO 11991 of May 24, 1977, directed the Council on Environmental Quality (CEQ) to issue regulations implementing the procedural provisions of the National Environmental Policy Act (NEPA). Accordingly, the CEQ issued these NEPA regulations in 40 CFR 1500 to 1508 on November 29, 1978. Several DOE orders and guidelines adopt NEPA and the CEQ guidelines as DOE policy. The MLLWTF project will proceed in accordance with these guidelines.

\subsection{National Environmental Policy Act (42 U.S.C. 4321-4347)}

Authority: $\quad 42$ U.S.C. $4321-4347$, 40 CFR 1500-1508, and DOE Order 5440.1D

All potential projects involving any Federal agency must undergo a review pursuant to NEPA to identify and evaluate potential environmental impacts. NEPA constitutes a national policy to protect the environment and to promote a better understanding of the ecological systems and naturai resources important to the nation. The CEQ regulations implementing NEPA contain "acionforcing" provisions to ensure that Federal agencies consider environmental information before making decisions on proposed actions. The NEPA process includes decision points at which the significance of environmental effects are considered, project alternatives are identified, and appropriate mitigation measures are identified and adopted.

DOE Order 5440.1D describes the roles of various DOE offices in implementing NEPA. It also states that it is DOE's policy to comply fully with the letter and spirit of NEPA. To ensure that environmental factors are considered in the decisionmaking process and to promote environmentally responsible decisions, DOE will incorporate NEPA requirements early in the planning process for proposed actions. DOE also will coordinate its NEPA activities with the states that host DOE facilities. DOE is committed to complete assessment and full disclosure of the environmental consequences of its proposed actions.

The DOE NEPA guidelines, 12-15-87 (52 FR 47662) as amended, 3-27-89 (54 FR 12474), and 9.7-90 (55 FR 37174), establish guidelines for implementing the procedural provisions of NEPA pursuant to the $C E Q$ regulations.

The proposed MLLWTF project would result in the construction and operation of a large-scale project. The proposed action would be considered to be a "major Federal action," with effects that 
might be significant and that are potentially subject to Federal control and responsibility. The MLLWTF would, therefore, require preparation of an environmental impact statement (EIS).

NEPA documentation is required to ensure that environmental concerns are addressed during project planning and decisionmaking. Because construction cannot begin until the NEPA process is complete, NEPA documentation requirements are addressed in this report. Currently, NEPA documentation for the MLLWTF is encompassed in the INEL Environmental Restoration and Waste Management EIS. The schedule for the INEL Environmental Restoration and Waste Management EIS is as follows:

- Draft EIS to public - October 1995

- Final EIS to public $\quad$ - January 1996

- Record of decision - February 1996.

\subsubsection{Preoperational Monitoring}

Authority: Atomic Energy Act of 1954, as amended, 40 CFR 1500-1508, and DOE Order 5400.1 .

DOE Order 5400.1, General Environmental Protection Program, specifies that preoperational monitoring activities should begin at least one year, and preferably two years, before startup to adequately cover seasonal changes. The activities are required to be complete before startup of the new facility. The preoperational monitoring activities shall:

- Characterize existing physical, chemical, and biological conditions that could be affected

- Establish background levels of radioactive and chemical components

- Characterize pertinent environmental and ecological parameters

- Identify potential pathways for human exposure or environmental impact as a basis for determining the nature and extent of the subsequent routine operational and emergency effluent monitoring and environmental surveillance programs.

Chapter IV, Part 3 of 5400.1 describes general guidance on baseline data collection. Some of the data reported for NEPA compliance may also satisfy requirements. Past and present monitoring programs at the INEL will provide much of the needed baseline data for the MLLWTF project. Additional studies may be required to summarize and evaluate data applicar': to the MLLWTF project and to expand the database on specific pollutants that will be released by MLLWTF operations. 


\subsection{DOE Crder 5480.4, Environmental Protection, Safety, and Health Protection Standards}

Authurity: Atomic Energ; Act

DOE Order 5480.4 specifies and provides requirements for the application of the mandatory environmental protection, safety, and health standards applicable to all DOE and DOE contractor operations. This order identifies the sources of the mandatory and reference environmental protection, safety, and health standards. Compliance with the following statutes and regulations is considered mandatory:

- National Historic Preservation Act of 1966

- Clean Air Act

- Clean Water Act

- Safe Drinking Water Act

- Coastal Zone Management Act of 1972

- Comprehensive Environmental Response, Compensation, and Liability Act

- Endangered Species Act of 1973

- Federal Insecticide, Fungicide, and Rodenticide Act

- Resource Conservation and Recovery Act of 1976

- Toxic Substances Control Act

- Noise Control Act of 1972.

\subsection{National Historic Preservation Act}

Awthority: $\quad 16$ U.S.C. 470 and E0 11593

Section 106 of the National Historic Preservation Act and implementing regulations (36 CFR 800) require a Federal agency with jurisdiction over any Federal or Federally assisted undertaking that inight affect historic properties or potentially eligible historic properties or sites to take the agency's effects on these properties into account. Section 110(f) of the Act requires that 
Federal agency heads, to the maximum extent possible, conduct planning and actions to minimize harm to any National Historic Landmark that may be directly and adversely affected by an undertaking.

The DOE, Advisory Council on Historic Preservation, and Idaho State Historic Preservation Officer (SHPO), require that projects potentially affecting undisturbed areas conduct an archeological survey/cousultative revicw. This review must be conducted in compliance with legislation including, but not limited to, the National Historic Preservation Act, the Archeological Resources, Protection Act of 1979, and the American Indian Religious Freedom Act. The MLLWTF requires this survey/consultative review. If archaeological resources are identified during the initial survey, the archaeologist's report will address the significance of the resources and make recommendations regarding the resource site (e.g., proceed with the project, avoid the site, conduct additional studies). The DOE-ID Environmental Protection Division (EPD) sends the archeologist's report to the SHPO for concurrence on the survey's recommendations. The SHPO review and response requires approximately one month.

The archaeological consultation process will be initiated during siting studies conducted for the MLLWTF. Past and present archeological surveys at the INEL will provide much of the needed survey results for ine MLLWTF project. Compliance with Section 106 of the Act will be documented in the facility EIS.

\subsection{Clean Air Act, as Amended (42 U.S.C. 7401 et seq.)}

Authority: $\quad 42$ U.S.C. 7401 et seq.

The Clean Air Act (CAA) legislates the prevention and control of air pollution to protect and enhance the quality of air resources of the nation. Section 118 of the CAA, as amended, requires that each Federal agency, such as DOE, with jurisdiction over any property or facility that might result in the discharge of air pollutants, comply with "all Federal, state, interstate, and local requirements" with regard to the control and abatement of air pollution.

The law deals with (a) air quality standards, (b) emission control limits, (c) ozone protection, (d) prevention of significant deterioration, (e) motor vehicle emission standards, (f) aircraft emission standards, (g) air quality control regions, and (h) state implementation plans. These standards and controls are administered through an air permitting program.

There are three types of national standards that the EPA is required to develop by regulation under the CAA: the National Ambient Air Quality Standards (NAAQS), New Source Performance Standards (NSPS), and National Emission Standards for Hazardous Air Pollutants (NESHAP). Each program serves a unique purpose. 


\subsubsection{CFR 50, National Ambiunt Air Quality Standards}

Authority: Sections 109 and 301(a) of the CAA, as amended [40 USCG 7409, 7601(a)]

The National Ambient Air Quality Standards (NAAQS) are established for pollutants of nationwide concern. Primary standards are established for the protection of human health and secondary standards are established for the protection of human welfare. Standards are promulgated for sulfur dioxide, particulates, carbon monoxide, photochemical oxidants, hydrocarbons, lead, and nitrogen dioxide. Attainment and maintenance of the standards are the primary responsibility of states.

\subsubsection{40 CFR 51, Requirements for Preparation, Adoption, and Submittal of Implementation Plans.}

Authority: Sections 101(b)1,110,160-169, 171-178, and 301 (a) of the CAA, as amended [42 U.S.C. 7401(b)(1), 7410, 7470-7479, 7501-7508, and 7601(a)]

The CAA requires each state to submit a state implementation plan (SIP) to the EPA, which includes nieasures to attain and measure the ambient air quality standards. Thus, the EPA establishes the national standards by regulation and the states enforce specific controls on sources through their SIPs. The State of Idaho's SIP has been approved by the administrator. Administrative authority for all air quality control programs, except that for NESHAP, have been delegated to the State (see Section 3).

\subsubsection{40 CFR 51.166, Prevention of Significant Deterioration of Air Quality.}

Authority: Sections 101(b)(1) and 160 of the CAA, as amended

The CAA includes special provisions for areas where the NAAQS are being attained to preserve them against significant deterioration. This is called the Prevention of Significant Deterioration (PSD) program. These regulations require a preconstruction review of all major facilities and major modifications. A major facility is a facility that has actual or allowable air emissions of 100 tors per year or more of any air contaminant. The INEL is considered a major facility and is located in a PSD Class II air quality area. A proposed new source must conduct studies to project its likely emissions and assess the impact on the ambient air quality to demonstrate that it will not contribute to a violation of the national air quality standards and will not excessively consume an increment of allowable air quality deterioration over the baseline air quality. The PSD program guarantees that areas that are in attainment with the NAAQS will remain that way. It requires that new sources be reviewed to demonstrate that they will not violate the NAAQS, that emissions will not violate statutory PSD increments, and that new facilities will employ the BACT. The INEL is in an attainment area for all parameters, unclassifiable as to State classification using CAA Section 107(d)(1)(D) and IDAPA 16.01.1002.97. (Authority delegated; see Section 3.) 


\subsubsection{40 CFR 51, Subpart P, Protection of Visibility.}

Authority: Sections $110,114,121,160-169,169 A$, and 301 of the CA.A, as amended (42 U.S.C. $7410,7414,7421,7470-7479$, and 7601)

The primary purpose of this subpart is to require states to develop programs to ensure reasonable progress toward meeting the national goal of preventing and remedying any future or existing impairment of visibility in mandatory Class I Federal areas where impairment results from man-made air pollution. The State of Idaho considers Craters of the Moon National Monument to be a Class I Federal area. It is located approximately 15 miles southwest of the INEL. (Authority delegated; see Section 3.)

\subsubsection{CFR 60 Standards of Performance for New Stationary Sources}

Authority: $\quad 42$ U.S.C. $7401,7411,7414,7416$, and 7601

The New Source Performance Standards (NSPS) regulate emissions on an industry-by-industry basis. These regulations establish standards of performance for new stationary sources that reflect the greatest degree of emission reduction. NSPS can involve restrictions in emissions, equipment design, and/or operation parameters. (Authority delegated; see Section 3).

\subsubsection{CFR 61, National Emission Standards for Hazardous Air Pollutants}

Authority: $\quad$ Sections 101,112, 114, 116, 301, CAA as amended (42 U.S.C. 7401, 7412, 7414, 7416, 7601)

The third category of national standards is the National Emission Standards for Hazardous Air Pollutants (NESHAP). These standards regulate pollutants that the EPA determines are particularly hazardous to health. These standards regulate both new and existing emission sources and limit the amounts of pollutants that may be emitted. The NESHAP standards are divided into general and specific provisions. The general provisions in 40 CFR 61 Subpart A describe the application procedures, general application information, application review process, variance request procedures, and other administrative activities. The specific provisions may specify emission limits, emission control procedures and techniques, emission control efficiencies, and testing and monitoring requirements. The materials regulated under the specific provisions of the NESHAP that may be applicable to the INEL include: radionuclides, benzene, volatile hazardous air pollutants, radon, mercury, vinyl chloride, beryllium, and asbestos.

The EPA requires a NESHAP document and approval for construction of sources of radionuclides from DOE facilities that would cause an effective dose equivalent (EDE) of greater than or equal to $0.1 \mathrm{mrem} / \mathrm{year}$, measured at the nearest residing member of the public. All new or 
modified sources of radionuclide emissions are sübject to DOE-ID approval. DOE-ID reviews all applications.

A separate application shall be submitted for each stationary source. Each application for approval of construction shall include (40 CFR 61.96):

- The name and address of the applicant and operation contractor

- The location or proposed location of the source

- The types of radionuclides to be emitted by the stationary source and the annual quantity (in Ci/year) emitted for each radionuclide

- A brief description of the nature, size, design, and method of operation of the stationary source, including the operating design capacity of each source and the point of emission for each hazardous pollutant

- An estimation dose equivalent rate to the nember of the public at the point of maximum annual air concentration in an unrestricted area where an individual resides or abides

- A description of the existing control equipment for each emission point, including primary control device(s) for radionuclide emissions, secondary control device(s) for radionuclide emissions, and estimated control efficiency (percent) for each control device.

If the source will cause an EDE of less than $0.1 \mathrm{mrem} / \mathrm{year}$, the EPA exempts the facility from applying for NESHAP approval. If the source is greater than $0.1 \mathrm{mrem} / \mathrm{year}$, DOE-ID will transmit the application to EPA Region X to obtain approval to construct. Construction may not commence until either an approval to construct has been issued by the EPA, or the application meets all the requirements of $40 \mathrm{CFR} 61$ and an approval to construct is not required. State regulations consider any emission rate of a pollutant not regulated to be significant (IDAPA 16.01.1002,86.b). This is especially true when radionuclide emissions are involved. Therefore, any facility with the potential to emit radionuclides must submit a State permit to construct application regardless of NESHAP applicability.

In addition to the NESHAP application, 40 CFR 61.94 requires that each facility (i.e., DOE-ID) submit to EPA an annual report that includes the results of monitoring emissions from points subject to the NESHAP regulations and associated dose calculations. This report is updated to indicate facility startups or shutdowns in the tirne-frame between reports.

Because of an agreement between the State of Idaho and EPA Region X, a NESHAP approval (if required) must be obtained from the EPA before the Idaho permit to construct (PTC)/PSD can be submitted to the State. This means the NESHAP must be approved in time to obtain the Idaho 
PTC/PSD. Collection of data for the NESHAP document is estimated to require three months. Preparation of a NESHAP document is estimated to require three months. This document would then be sent to DOE-ID Programs (estimated three months for review), then to DOE-ID EPD (estimat ihree months for review). After the document has been approved by DOE-ID, it will be transmitted to the EPA for review. Regulation 40 CFR 61.08 states that the administrator will notify the owner of approval or intention to deny approval within 60 days after receipt of sufficient information to evaluate an application. The actual estimated time for EPA Region X approval is six months. This allows for the 60 days plus the statement allowing for sufficient information. Total estimated time for data collection, preparation, review, and approval is 18 months.

Analysis to determine if NESHAP approval is necessary must be conducted for any facility that will emit, or has the potential to emit, any hazardous material listed in these regulations. This analysis and/or approval must be sent to the State of Idaho with the application for PTC/PSD. The following steps identify the information needed for the NESHAP document:

1. Identify all sources of emissions associated with the project

2. Establish any hazardous material emissions (listed in 40 CFR 61, including radioactive emissions) and what control equipment will be in place

3. Conduct EPA-approved modeling for any emissions from Step 2, above, and for any source of radioactive emissions, such as ponds or stacks, conduct EPA air dose modeling

4. Calculate EDE for maximum exposed individual for each MLLWTF emission source at the site boundary. If above 0.1 mrem, NESHAP approval is required. If below 0.1 mrem, NESHAP approval is not required.

To complete the modeling, some Title II design parameters are needed. These include:

- Stack parameters, such as stack diameter, velocity, flowrate, height, and exit temperature

- Location of point of emissions (such as stack location)

- Location and size of nearby buildings.

Environmental data needed to complete the modeling include:

- Meteorological parameters supplied by the National Oceanic and Atmospheric Administration (NOAA)

- Agricultural data (number of livestock and agricultural products produced in each sector) 
- Radionuclide transfer data derived from primary technical reports.

NESHAP documentation preparation could start as soon as the specified Title II design parameters are complete. This could be accomplished prior to complete Title II design approval by bounding the specified parameters. Bounded design parameters are defined as those parameters that will directly affect the facility emissions and that will remain within the boundaries that were established after a specified point in time in the design. Thus, if the design of the heating, ventilating, and air conditioning system, stack velocities, stack height, and filtering requirements, etc., can be bounded prior to the completion of Title II, the permitting process can proceed prior to Title II design approval.

\subsection{Clean Water Act, as Amended (33 U.S.C. 1251 et seq.)}

Authority: $\quad 33$ U.S.C. 1251 et seq.

The Clean Water Act's (CWA) stated objective is to "restore and maintain the chemical, physical, and biological integrity of the nation's waters." The CWA prohibits the discharge of pollutants in toxic amounts to navigable waters of the United States. Section 313 of the Act, as amended, requires all branches of the Federal Government engaged in any activity that might result in a discharge or runoff of pollutants to surface waters to comply with Federal, state, interstate, and local requirements.

The Act has five main elements:

- A permit program

- A system of minimum national effluent standards for each industry

- Water quality standards

- Provisions for special problems, such as toxic chemicals and oil spills

- A construction grant program for publicly owned treatment works.

\subsubsection{National Pollutant Discharge Elimination System (NPDES) (40 CFR 122)}

Authority: Sections 304, 307, 318, 402 and 405 of the CWA, 33 U.S.C. 1251 et seq.

The CWA's primary mechanism for imposing limitations on pollutant discharges is a nationwide permit program established under Section 402 and referred to as the National Pollutant Discharge Elimination System (NPDES). NPDES activities include issuing, modifying, revoking, reissuing, and 
terminating permits. In addition, NPDES monitors and enforces permit requirements, and imposes and enforces pretreatment requirements.

The NPDES program imposes detailed pollution control requirements for industrial effluents through permits issued by the EPA or by states having a permit program approved by the EPA. The EPA has not authorized the State of Idaho to issue NPDES permits. If required, the EPA will issue a NPDES permit for the INEL.

DOE-ID determines if the proposed action will discharge pollutants or waste from any "point source" into waters of the United States (40 CFR 122.1 and 122.2). If the facility is a new source, construction may not commence until the issuance of the permit.

Since no discharge to surface waterways or municipal water systems is anticipated, an NPLES permit is not presently required for the MLLWTF. However, beginning October 1, 1992, storm water discharges (storm water point sources) will be subject to the NPDES program (40 CFR 122.26). DOE-ID plans to obtain a general NPDES permit for all existing facilities on the INEL. New facilities will be a modification of this NPDES permit.

\subsection{Safe Drinking Water Act, as Amended [42 U.S.C. 300 (f) et seq.]}

Authority: $\quad 42$ U.S.C. $300(f)$ et seq.

The Safe Drinking Water Act was enacted in 1974 to ensure safe drinking water supplies, protect especially valuab!e aquifers, and protect drinking water from contamination by the underground injection of waste. The implementing regulations are found in 40 CFR 141. National Interim Primary Drinking Water Regulations. These regulations are administered by the EPA and establish standards applicable to public water systems. They promulgate maximum allowable contaminant levels, including those for radioactivity, in community water systems. These systems are defined as public water systems that serve at least 15 service connections used by year-round residents or regularly serve at least 25 year-round residents. (Authority delegated; see Section 3.)

\subsection{Executive Orders 11988 and 11990}

Authority: President

EO 11988 (Floodplain Management) and EO 11990 (Protection of Wetlands) require governmental agencies to avoid, to the extent possible, the long-term and short-term adverse impacts associated with the destruction of wetlands, and the occupancy and modification of floodplains and wetlands whenever there is a practicable alternative. DOE has issued regulations in 10 CFR 1022 that establish DOE procedures for compliance with these executive orders. 
EO 11988 requires each Federal agency to review its proposed actions to determine if any action will occur in a floodplain. The potential effects of an action occurring in a floodplain must be evaluated. DOE-ID shall consider alternatives to avoid adverse effects and incompatible development in floodplains.

If, after reviewing alternatives, DOE-ID determines to take action in a floodplain, the facility shall be designed to minimize potential harm to or within the floodplain, and to restore and preserve floodplain values. DOE shall publish, in the Federal Register, a brief description of the measures to be employed and shall strive to notify appropriate Federal, State, and local agencies and persons or groups known to be interested in the action. Early public review of the proposed action is required. Public comments shall be incorporated into the decision documentation on the project.

Construction shall be in accordance with the regulations promulgated by the Federal Insurance Administration pursuant to the National Flood Insurance Act of 1968, as amended.

Floodplain facility sites within the 100-year floodplain will be excluded from the INEL MLLWTF candidate site selection process, and areas within the 500-year floodplain areas will be avoided or receive lowest siting priority in accordance with DOE Order 6430.1A, General Design Criteria. A wetland review will also be conducted as part of the siting study. No wetlands are expected to be impacted by the MLLWTF at the INEL.

\subsection{Endangered Species Act, as Amended (16 U.S.C. 1531 et seq.)}

Authority: $\quad 16$ U.S.C. 1531 et seq.

The Endangered Species Act, as amended, was enacted to protect threatened and endangered species and their critical habitat. The Act was intended to bring about the restoration of these species and their habitats and is administered by the Department of Commerce and the Department of the Interior. Section 7 of the Act requires consultation to determine whether endangered and threatened species are known to have critical habitats on or in the vicinity of the proposed Federal action. 50 CFR Part 17, Subpart B, contains a list of endangered and threatened species. No such species are expected to be impacted by the MLLWTF at the INEL.

Compliance with this Act involves an ecological survey and submitial of ecological data to and consultation with the United States Fish and Wildilife Service (FWS), Idaho Fish and Game, and the Bureau of Land Management (BLM). These surveys and consultations should be conducted during the candidate MLLWTF site reviews at the INEL. The Idaho Fish and Game, BLM, and U.S. FWS should be contacted and consulted prior to initiating construction activities. 


\subsubsection{Fish and Wildife Coordination Act (16 U.S.C. 661-666C)}

Authority: $\quad 16$ U.S.C. $661-666 \mathrm{C}$

Before the waters of any stream or other body of water greater than or equal to 10 acres in surface area can be impounded, controlled, or modified, the FWS, Department of Interior, and head of the Idaho Fish and Game Department must be consulted. This Act requires that consideration be given to the conservation of tish and wildlife resources during the development of any DOE projects that affect water resources directly or indirectly. DOE must cooperate with State and Federal wildlife agencies in assessing project impacts to fish and wildlife. There are no permitting requirements.

This Act is not applicable to the MLLWTF since the project is not expected to impound, control, or modify the waters of a stream or other body of water that is greater than or equal to 10 acres in surface area.

\subsection{Migratory Bird Treaty Act, as Amended (16 U.S.C. 703 et seq.)}

\section{Authority: $\quad 16$ U.S.C. 703 et seq.}

The Migratory Bird Treaty Act, as amended, is intended to protect birds that have common migration patterns between the United States and Canada, Mexico, Japan, and Russia. It regulates the harvest of migratory game birds by specifying the mode of harvest, hunting seasons, bag limits, etc. Although no permit for this project is required under the Act, DOE is required to consult with the FWS regarding impacts to migratory birds and to evaluatc ways to avoid or minimize the effects in accordance with the FWS mitigation policy (Department of the Interior, 1981).

\subsection{Bald and Golden Eagle Protection Act, as Amended (16 U.S.C. 668-668d)}

Authority: $\quad 16$ U.S.C. $668-668 d$

The Bald and Golden Eagle Protection Act makes it unlawful to take, pursue, molest, or disturb bald (American) and golden eagles, their nests, or their eggs anywhere in the United States. A permit must be obtained from the Department of the Interior to relocate a nest that interferes with resource development or recovery operations (Section 668a).

There are no permit or approval procedure requirements unless a nest is found; in that case, DOE will attempt to obtain permission from the Secretary of the Interior to move the nest pursuant to Section $668 \mathrm{a}$, claiming interference with resource development. 


\subsection{Noise Control Act of 1972, as Amended (42 U.S.C. 4901 et seq.)}

Authority: $\quad 42$ U.S.C. 4901 et seq.

Section 4 of the Noise Control Act of 1972, as amended, directs all Federal agencies to carry out, "to the fullest extent within their authority," programs within their jurisdictions in a manner that furthers a national policy of promoting an environment free from noise that jeopardizes health or welfare.

\subsection{Resource Conservation and Recovery Act, as Amended (42 U.S.C. 6901 et seq.)}

Authority: Sections 1006, 2002(a), 3001 through 3007, 3010, 3014, 3015, 3017, 3018, and 3019 of the Solid Waste Disposal Act, as amended by the Resource Conservation and Recovery Act (RCRA) of 1976, as amended (42 U.S.C. 6901 et seq.), and 40 CFR 260-280

The Resource Conservation and Recovery Act (RCRA), as amended, governs the generation, handling, treatment, storage, and disposal of solid and hazardous materials and waste, and the use of underground storage tanks. The implementing regulations are found in 40 CFR 260-280 and define and identify various types of hazardous waste and specify how the various types of hazardous waste must be transported, handled, and disposed.

RCRA permitting applies to hazardous waste and mixed waste treatment, storage, and disposal facilities (TSDFs) at the INEL. Mixed waste covers all radioactive waste also meeting a hazardous classification under RCRA.

Before initiation of construction or modification, all new TSDFs and changes to existing TSDFs during interim status must be identified through the permitting process. The INEL MLLWTF will be designed for storage and treatment of mixed waste and, therefore, requires a RCRA permit. The State of Idaho received RCRA primacy in April of 1990. At this time, the State plans on following the Federal RCRA guidelines. (Refer to Section 3.)

\subsection{DOE Order 5820.2A, Radioactive Waste Management}

Anthority: The Atomic Energy Act

DOE Order 5820.2A establishes policies and guidelines for the management of radioactive waste, waste by-products, and radioactively contaminated surplus facilities. The objective of this order is to ensure that DOE operations adequately protect public health and safety in accordance with radiation protection standards; the INEL MLLWTF project will abide by this order. 
This order defines key terms and specifies lines of authority. Chapter III establishes the policies and guidelines for managing low-level waste and specifies criteria for site selection, design, and disposal-site operations. This order provides for treating low-level waste to ensure that the disposal facilities will meet the acceptable performance objectives. This order also mandates that low-level waste be managed on a systematic basis using a combination of waste reduction, segregation, treatment, and disposal practices to maximize the overall system cost-effectiveness.

\subsection{DOE Ter 5400.3, Hazardous and Radioactive Mixed Waste Program}

Authority: Atomic Energy Act and the Solid Waste Disposal Act, as amended by RCRA

DOE Order 5400.3 establishes policias and requirements for the management of hazardous and radioactive mixed waste, and implements the requirements of RCRA within the environmental programs established under DOE 5400.1.

This order states that it is the policy of DOE to manage all departmental hazardous and radioactive mixed waste according to the requirements of Subtitle C of RCRA and the AEA, respectively. RCRA applies to the extent that it is not inconsistent with the AEA.

\subsection{Land Disposal of Solid Waste}

Authority: $\quad$ Section 209(a) of the Solid Waste Disposal Act of 1965, as amended by the RCRA of 1970 , and 40 CFR 241.

Authority delegated; see Section 3.

\subsection{Nonhazardous Wastewater Treatment (Except Land Application)}

Authority: The CWA (33 USCG 1251, et seq), DOE Order 5400.1

Any construction or modification of any sewage treatment plant, sewage treatment system, or other wastewater treatment or disposal facility not using land application methods requires submittal of plans and specifications to the DOE-ID EPD at least 60 days before initiation of construction for review and approval.

In accordance with State wastewater treatment regulations, DOE installations at the INEL operate INEL wastewater treatment systems in compliance with applicable Federal requirements and State of Idaho requirements as in the Idaho Administrative Procedures Act (IDAPA) 16.01.2000. If actual construction deviates from the approved plans and specifications, then the plans and specifications depicting the actual construction, modification, or alternative as-built shall be submitted 
to DOE-ID within 30 days of project completion. INEL nonhazardous wastewater treatment facilities do not currently require State of Idaho permits.

Idaho regulations require a review of plans to construct or modify private or publicly-owned sewage treatment plants or operations by the Idaho Department of Health and Welfare (IDHW). Individual and subsurface sewage treatment/disposal system plans are reviewed by the appropriate IDHW. DOE will notify the appropriate State agency of plans to install sewage treatment equipment.

The INEL. MLLWTF may construct or modify a sewage treatment process depending on the siting and the proximity of the facility to other existing facilities that could provide treatment needs. Review and approval of these activities is therefore applicable to the MLLWTF.

\subsection{Nonhazardous Wastewater Treatment by Land Application}

Authority: $\quad$ CWA (42 U.S.C. 1251 et seq), DOE Order 5400.1

Construction, modification, or operation of a facility for the treatment or disposal of industrial or municipal wastewater by application to land requires submittal of an application by DOE-ID Programs to the Technical Support Division for review and submittal on all existing and planned facilities at least 180 days before initiation of construction. The application shall contain the following information:

- Name, location, and mailing address of the facility

- Name, mailing address, and phone number of the facility owner and signature of the owner or authorized agent

- Nature of the entity owning the facility

- A list of local, State, and Federal permits, licenses, and approvals related to the activity that have been applied for and that have been received and the dates of application or approval

- A topographic map of the facility site identifying and showing the location and extent of:

- Wastewater inlets, outlets, and storage structures and facilities

- Wells, springs, wetlands, and surface waters

- 25-, 50-, and 100-year floodplains 
- Service roads

- Natural or man-made features necessary for treatment

- Buildings and structures

- Process chemicals and residue storage facilities

- A topographic map (separate or combined with above), extending 1/4 mile beyond facility site outer limits, that identifies and shows the location and extent of the following:

- Springs, wetlands, and surface waters

- Public and private drinking water supply sources

- Public roads

- Dwellings, and public and private gathering places

- The volume of wastewater to be treated and the time distribution of flows

- The physical, chemical, and biological characteristics of the wastewater

- The climatic, hydrogeologic, and soil characteristic of the site.

Proposed facilities require a plan of operation to be written by the time the facility construction is $50 \%$ complete. Further, the plan must be updated to reflect actual operation after one year of operation. All requirements in the applicable regulations (IDAPA 16.01.17000) shall be followed.

The INEL's major facilities use wastewater treatment by land application for their sewage wastewater effluents, which are monitored monthly. At this time, the MLLWTF is not considering disposal by land application. The preceding guidelines have been included into this compliance plan in the event that wastewater treatment by land application becomes applicable.

\subsection{Toxic Substance Control Act of 1976}

Authority: 15 U.S.C. 2605, 2607, and 2611; Subpart G also issued under 15 U.S.C. 2614 and 2616

Toxic Substances Control Act (TSCA) permitting applies to any facility that plans to incinerate polychlorinated biphenyls (PCBs). All PCB incinerators must be identified to the EPA through a permitting/approval process before initiation of any burn. 
The State of Idaho does not administer the TSCA program, but incineration approval will interface with associated permitting required by the Idaho Air Quality Bureau (IAQB).

Requests for approval of incinerators must meet all of the design/combustion criteria and requirements specified in 40 CFR 761.70. Application information must be submitted to the DOE-ID EPD and transmitted to the EPA. The EPA will review the application and determine if the operation may proceed, if a test burn is required, or what difficiencies must be addressed.

Applications and approvals to incinerate PCBs must be completed before any incineration of PCB materials. The approval process is expected to take one year. The application submitted to the EPA shall include:

- The location of the incinerator

- A detailed description of the incinerator, including general site plans and design drawings of the incinerator

- Engineering reports or other information on the anticipated performance of the incinerator

- Sampling and monitoring equipment and facilities available

- Waste volumes expected to be incinerated

- Any local, State, or Federal permits or approvals

- Schedules and plans for complying with the approval requirements of this regulation.

The MLLWTF may request a PCB incinerator permit if analysis of the INEL waste streams identify that this capability is nceded and other treatment possibilities do not exist. The waste stream definition analysis for this project is currently being performed. 


\section{STATE OF IDAHO REGULATIONS AND GUIDELINES}

\subsection{Idaho Environmental Protection and Health Act}

Authority: Idaho Code Title 39, Chapter 1

This Act establishes general provisions for protection of the environment and public health. The IDHW has been created by this Act to implement these environmental, health, and social services requirements. The Act authorizes the Department to promulgate standards, rules, and regulations relating to water and air quality, noise reduction, and solid waste disposal. The Department is granted authority to issue required permits, collect fees, establish compliance schedules, and review plans for the construction of sewage and public water treatment and disposal facilities.

\subsection{Idaho Air Pollution Contrel Regulations}

Authority: The CAA, as amended, and IDAPA Title 1, Chapter 1, of the Rules and Regulations for the Control of Air Pollution in Idaho

The IDHW has been granted authority by the Federal Government to implement some, but not all (i.e., NESHAP), of the requirements of the CAA and to adopt rules and regulations for that purpose. These rules and regulations include provisions for establishing compliance schedules and emission limits, reporting and correction of emissions that exceed established limits, and permitting requirements for construction and operation of facilities or activities that may generate emissions in excess of the prescribed standards. The control of open burning and fugitive dust is addressed by these rules, as are specified types of facilities that may exceed emission limits. The formulation of a plan for the prevention and alleviation of air pollution emergencies is also required by the Idaho Air Pollution Con'rol Regulations. The plan includes definitions of the severity of the emergency, requirements for public notification, and recommended actions to be taken in abating an air pollution emergency.

\subsubsection{Idaho Permit to Construct/Prevention of Significant Deterioration}

Authority: The CAA, as amended, 40 CFR 51, Idaho Code (Sections 39-105, 39-107), and IDAPA 16.01 .1012

IDAPA 16.01.1012, Procedures and Requirements for Permits to Construct and Operation Permits, establishes uniform procedures for the issuance of permits to construct (PTC) and operating permits. A PTC must be obtained prior to construction or modification of any stationaráy source, major facility, or major modification, except for the classes of equipment listed in IDAPA $16.01 .1012,02$. Stationary source is broadly defined to mean any building, structure, emissions 
unit, or installation that emits or may emit any air contaminant (IDAPA 16.01.1002,96). An air contaminant is defined to include dust, fume, gas, mist, odor, smoke, vapor, pollen, soot carbon, or particulate matter regulated by the EPA or Federal CAA (IDAPA 16.01.1002,02.c.).

Depending on the proposed size and location of the new or modified stationary source or facility, the application for a permit to construct shall include the information required by one or more of the following provisions:

- For any new or modified stationary source or facility:

- Site information, plans, descriptions, specifications, and drawings showing the design of the stationary source, facility, or modification; the nature and amount of emissions (including secondary emissions); and the manner in which it will be operated and controlled

- A schedule for construction of the stationary source, facility, or modification.

- For any new major facility or major modification in an attainment or unclassifiable area (the INEL has been classified by the State as an attainment area for all parameters, unclassifiable, using CAA Section 107(d)(1)(D) and IDAPA 16.01.1002,91) for any air contaminant, the following is required:

- A description of the system of continuous emission control for the proposed major facility, emission estimates, and other information as necessary to determine that the BACT is applied.

- An analysis of the effect on air quality by the new major facility or major modification, including meteorological and topographical data necessary to estimate such effects.

- An analysis of the effect on air quality projected for the area as a result of general commercial, residential, industrial, and other growth associated with the new major facility or major modification.

- A description of the nature, extent, and air quality effects of any or all general commercial, residential, industrial, and other growth that has occurred since August 7 , 1977 , in the area the new major facility or major modification would affect.

- An analysis of the impairment to visibility, soils, and vegetat on that would occur as a result of the major facility and general growth associated with establishment of the major facility. The owner or operator need not provide and analysis of the impact on vegetation or soils that have no significant commercial or recreational value. 
- An analysis of the existing ambient air quality in the area affected by the major facility for each air contaminant that the major facility would emit in significant amounts or for which a major modification would result in significant net emissions increase.

- No analysis is needed if the projected increases in ambient concentrations or existing ambient concentrations of a particular air contaminant in any area affected by the major facility are less than the amounts listed in IDAPA 16.01.1012,04.a.iii(h).

- For any air contaminant that has an ambient air quality standard, the analysis shall include continuous air monitoring data gathered over the year preceding the submittal of the application, unless the Department determines that a complete and adequate analysis can be accomplished with monitoring data gathered over a period shorter than one year, but not less than four months, which is adequate for determining whether the emissions of that air contaminant would cause or contribute to a violation of the ambient air quality standard or any PSD increment.

- For any air contaminant that does not have an ambient air quality standard, the analysis shall contain such air quality monitoring data that the Department determines is necessary to assess ambient air quality for that air contaminant in any area that the emissions of that air contaminant would affect.

- If requested by the Department, monitoring of visibility in any Class I area the proposed major facility would affect.

- Operation of monitoring stations shall meet the requirements of Appendix B 40 CFR 58 or such other requirements as extensive as those set forth in Appendix B as may be approved by the Department.

All estimates of ambient concentrations shall be based on the applicable air quality models, databases, and other requirements specified in the EPA's "Guidelines on Air Quality Models" (OAQPS 1.2-080).

Any additional information, plans, specifications, evidence, or documents that the Department may require to make the determinations required under IDHW Rules and Regulations Section 01.1012 shall be furnished upon request.

State of Idaho regulations do not define the level of detail of the engineering data needed for a PTC; however, to perform the analysis needed, some Title II design parameters will be required. The analysis can be performed as soon as Title II design is approved or as soon as the needed Title II design parameters are bounded. The needed Title II design parameters are the same as described for the NESHAP analysis in Section 2. In addition, drawings showing design of source, location of 
emission sources, and estimated emission rates for criteria pollutants and toxics are needed for the facility.

PSD review by the State of Idaho is automatic for a radiological source regulated by the EPA under NESHAP. The application process for a PTC/PSD permit includes the PTC permit information, as well as a NESHAP approval if required.

The IAQB will not issue a PTC/PSD for a major facility in an attainment or unclassifiable area unless the applicant can show that (IDAPA 16.01.1012,07):

- The BACT will be used for each air contaminant that would have significant allowable emissions at each emissions unit that has a new emission increase

- The allowable emission increase, in conjunction with all other applicable emission increases, would not cause or significantly contribute to violations of any ambient air quality standard

- The allov able emission increases would not have an adverse effect on air quality related values, including visibility of any Class I area. The closest PSD Class I air quality area is Craters of the Moon National Monument, which is about 15 miles southwest of the INEL.

The NESHAP analysis is required to be submitted to the State along with the PTC/PSD application. The PTC/PSD application will not be reviewed by the IAQB until the EPA has approved the NESHAP document (if EPA approval is required, see Section 2). Data collection and preparation of the PTC/PSD application may be started prior to this approval. The estimated time for data collection is one year. Preparation of the application is estimated to take six months. The draft application is reviewed by DOE-ID Programs and the DOE-ID EPD (estimated review time is six months). After the application has been approved by DOE-ID, it is sent to the IAQB for review and approval (estimated review time is one to two years).

3.2.1.1 Operating Permits. Operating permits are similar to PTCs in that such permits include descriptions of operations at a particular facility, subfacility, or plant; limitations on operating parameters; limitations on emission levels; and monitoring and reporting requirements.

Operating permits are needed to authorize the use of various emissions trading activities. Such activities include the use of aiternative emissions limits (bubbles), emission offsets, emission netting transactions, and the banking of emission reduction credits. Emission bubbles and offsets are normally only applicable for nonattainment areas and, therefore, do not apply to the INEL. Operating permits are also issued in conjunction with SIPs, in the permitting of previously unpermitted sources, and in the updating of expired or outdated PTCs or operating permits of existing sources. DOE-ID plans to obtain an operating permit for the entire INEL to provide permit limits for all existing sources. New facilities will be a modification of this operating permit. 


\subsection{Idaho Water Quality Standards and Wastewater Treatment Requirements}

Authority: IDAPA Title 1, Chapter 2, and Idaho Code (Section 39-105)

Provisions are set forth by these regulations for protection of designated water uses and the establishment of water quality standards that will protect those uses. The IDHW has been authorized to develop and enforce these regulations by Section 39-105 of the Idaho Code. Restrictions are outlined by these regulations for control of point-source and nonpoint-source discharges and other activities that may adversely affect waters of the State of Idaho, including surface and ground waters. These regulations identify water use classifications, specifically prohibited discharges, water quality criteria, and requirements for treatment of wastewater prior to discharge to the waters of Idaho.

\subsubsection{Production Water Wells}

Authority: IDAPA 16.01.8601.01; Rules and Regulations, Well Construction Standards, State of Idaho Department of Water Resources (IDWR), February 1981; and DOE Orders $5400.1,5480.1$, and 5480.4

Construction of any industrial or domestic production water well requires that a notification be sent to DOE-ID for approval to construct a production water well. The well construction specifications must be approved by DOE-ID and are required to be in full compliance with the appropriate IDHW Department of Environmental Quality (DEQ) requirements. The following well construction specifications, as stated in IDAPA 16.01 .8601 , must be supplied to DOE-ID:

- Well location provisions

- Minimum construction standards establish əd by the Idaho Water Resources Board

- Well sample tap

- Discharge tap

- Well casing vent specifications

- Pressure gauge requirements

- Well casing and seal requirements

- Well house requirements 
- Well lot provisions

- Well site approval.

Well specifications should be submitted to DOE-ID as early as possible in the planning process to allow for review and for any changes that may be deemed necessary. Preparation time is estimated to be one year; review and approval time is estimated to be one year.

\subsubsection{Idaho Regulations for Public Drinking Water Systems}

Authority: Safe Drinking Water Act (42 U.S.C. $300 \mathrm{~F}$, et seq.), DOE Order 5400.1, and IDAPA 16.01 .8000 .

All INEL drinking water systems are considered noncommunity, nontransient public drinking water systems.

The Idaho DEQ has primacy for implementing the Safe Drinking Water Act provisions. An engineering report shall be submitted to the DEQ through DOE-ID prior to the construction of any new public water supply or the modification of any existing system. The engineering report shall contain the following information (at Title II design level for the drinking water system):

- A general description and location of the project

- The estimated design population of the project

- Design data for domestic, irrigation, fire-fighting, commercial, and industrial water demands

- Storage requirements

- Pressure ranges for normal and peak flow conditıons

- A hydraulic analysis of the distribution system if requested by the Department

- Adequacy, quality, and availability of sources of water

- Potential sources of contamination to proposed sources of water

- Mechanisms for protection of the system from flooding 
- The following additional information is required for groundwater sources:

- A site plan, including potential sources of contamination within 500 feet of a well or spring

- Dimensions of the well lot

- Underground geological data and existing well logs.

Plans and specifications for construction of new public water supply systems or modification to an existing water supply system must be submitted to IDHW DEQ for review and approval. The minimum requirements for review are as follows:

- Submittal must be signed by an Idaho-registered professional engineer (PE) and bear the imprint of the PE's seal

- Plans shall provide topographical data

- Plans shall show the location of sources or potential sources of contamination

- Plans shall specify that the project is to be disinfected before use to meet American Water Works Association Standards.

The design of new public drinking water systems shall be in conformance with the 1982 edition of Recommended Standards for Water Works. Upon completion of a groundwater source, the following information and data shall be submitted to the DEQ:

- A copy of all geophysical logs

- Test pumping data for all wells, including sand production, static water level, yield, drawdown, and duration of test pumping

- As-constructed plans showing at least the following:

- Surface seal

- Casing

- Casing perforations, screens, and gravel packs 
- $\quad$ Pump location

- $\quad$ Results of a nitrate sample.

The test pumping shall be conducted according to the following procedures and requirements:

- A small capacity well yielding less than $50 \mathrm{gpm}$ shall be test pumped for a minimum of four hours at a rate equal to the permanent pump rate or until the drawdown has stabilized

- A large capacity well, greater than $50 \mathrm{gpm}$, shall be test pumped at a rate of $125 \%$ of the desired yield of the well. The test period shall be a minimum of six hours and the drawdown shall have stabilized. If the test cannot be performed satisfactorily, the design must be reevaluated and resubmitted to the DEQ

- Fifteen minutes after the start of the test pumping, the sand content of a new well shall not be more than $5 \mathrm{ppm}$. Sand production shall be measured by a centrifugal sand sampler or equivalent. If sand production exceeds $5 \mathrm{ppm}$, the well shall be screened and gravel packed.

During construction or modification of the drinking water system, no deviation can be made from the approved plans without written approval from the DEQ. If plans have changed, "asconstructed" plans and specifications shall be submitted to the DEQ by an Idaho PE. If plans remain as originally submitted, an Idaho PE shall certify in writing that the "as-constructed" plans and specifications are the same as the originals.

Submittal of the engineering report and the plans/specifications must be made to the IDHW DEQ at least 60 days before initiation of construction. Within 30 days after project completion, the "as-constructed" plans/specifications or the "as-approved" certification statement shall be submitted to the DEQ. Adequate time (30 days) must be allowed for DOE-ID review prior to the submittal deadline. The estimated total time needed before construction is one year.

\subsection{Idaho Solid Waste Management}

Authority: Solid Waste Disposal Act, 40 CFR 241, and IDAPA 01.6000

The Idaho Solid Waste Management regulations, developed by the IDHW in Title I, Chapter 6, of the Solid Waste Management Regulations and Standards, provide regulations and standards for the management of solid waste to protect public health and welfare. 


\subsubsection{Land Disposal of Solid Waste}

Authority: $\quad$ Solid Waste Disposal Act, 40 CFR 242, and IDAPA 16.01.6000

All nonhazardous, solid waste at the INEL is disposed of in the INEL sanitary landfill. The INEL landfill conforms to the standards listed in IDAPA 16.01.6008. To ensure compliance with the regulations, waste acceptance criteria (WAC) have been established for the INEL landfill. The INEL MLLWTF project will comply with this WAC. No land disposal permit or consultation is required for the INEL MLLWTF project.

\subsection{Idaho Hazardous Waste Management}

Authority: $\quad$ RCRA of 1976, Hazardous Waste Management Act of 1983, as amended, Idaho Code (Sections 39-4401 et seq.), 40 CFR Parts 124, 260-266, 268, 270, IDAPA 16.01 .5000 .

RCRA requires any facility that treats, stores (except in satellite and temporary accumulation areas), or disposes of hazardous or mixed waste to obtain a RCRA permit. The RCRA permit process consists of two parts: Part A, interim status, and Part B, final permit (40 CFR 270). Part A contains general information on the facility and also includes the hazardous waste listed or designated under 40 CFR 261 and a description of the processes to be used for the treatment of such waste. Part B contains detailed information on the nature and scope of activities at the facility, such as a waste analysis plan, security procedures, inspection schedule, contingency plan, training plan, and closure plan. The operating contractor notifies DOE-ID and the EG\&G Idaho permitting coordinator of the proposed action, which results in the preparation of a new permit application or modification of the existing permit. No physical construction of a new facility shall begin without having submitted Parts A and B (together) of the RCRA permit application to the State of Idaho Hazardous Materials Bureau and having received an approved and effective RCRA permit (40 CFR 270.10(f)).

The INEL MLLWTF does not qualify for interim status; therefore, both a Part A and a Part B permit application must be submitted and approved prior to construction. The application request must be submitted during the detailed design phase. The estimated time involved for EG\&G Idaho to prepare and submit the permit application to the State is one year. It generally takes the State three to five years to draft and approve the RCRA permit, depending on the type of treatment unit.

Permits may be issued for a term not to exceed 10 years (40 CFR 270.50). All RCRA hazardous waste management facilities must have permits throughout their active lives. When a facility is owned by one entity (e.g., DOE) and operated by another (e.g., EG\&G Idaho), both parties are involved in obtaining the permit. Both the owner and operator must sign and certify that they understand the contents of the permit. 


\subsection{Underground Storage Tanks}

Authority: Solid Waste Disposal Act [Sections 9001 and $9003(\mathrm{~g})$ ], as revised by the RCRA, as amended, 40 CFR 280

An underground storage tank (UST) is defined in 40 CFR 280.1 as any one or a combination of tanks (including the underground piping system) that is used to contain an accumulation of regulated substances, and the volume of which (including the underground piping system) is $10 \%$ or more beneath the surface of the ground. The following are not considered USTs:

- Farm or residential tanks

- Tanks used for storing heating oil for consumptive use ( 1 the premises where stored

- Septic tanks

- $\quad$ Pipeline facilities

- Surface impoundments, pits, ponds, or lagoons

- Storm system or wastewater collection system

- Flow-through process

- Storage tank situated in an underground area (such as a basement) if the storage tank is situated upon or above the surface of the floor.

The requirements of $40 \mathrm{CFR}$ do not apply to the following:

- Any UST system holding hazardous waste listed or identified under Subtitle C of the Solid Waste Disposal Act, or a mixture of such hazardous waste and other regulated substances

- Any wastewater treatment tank system that is part of a wastewater treatment facility regulated under Section 402 or 307 (b) of the CWA.

Notification is required for any new USTs. The notification is submitted, using the EPA form in 40 CFR 280, Appendix I, to the Idaho Underground Tank Coordinator, Water Quality Bureau, Idaho Department of Health and Welfare, Division of Environment, $450 \mathrm{~W}$. State Street, Boise, Idaho, 83720. The notification must be submitted within 30 days of bringing new tanks into use. 
At this time, the MLLWTF is not considering the use of USTs during the construction or operation of this project. The preceding guidelines have been included in this compliance plan in the event that the use of USTs becomes applicable. 


\section{Attachment 1}

INEL MLLWTF Permitting and Approval Summary 


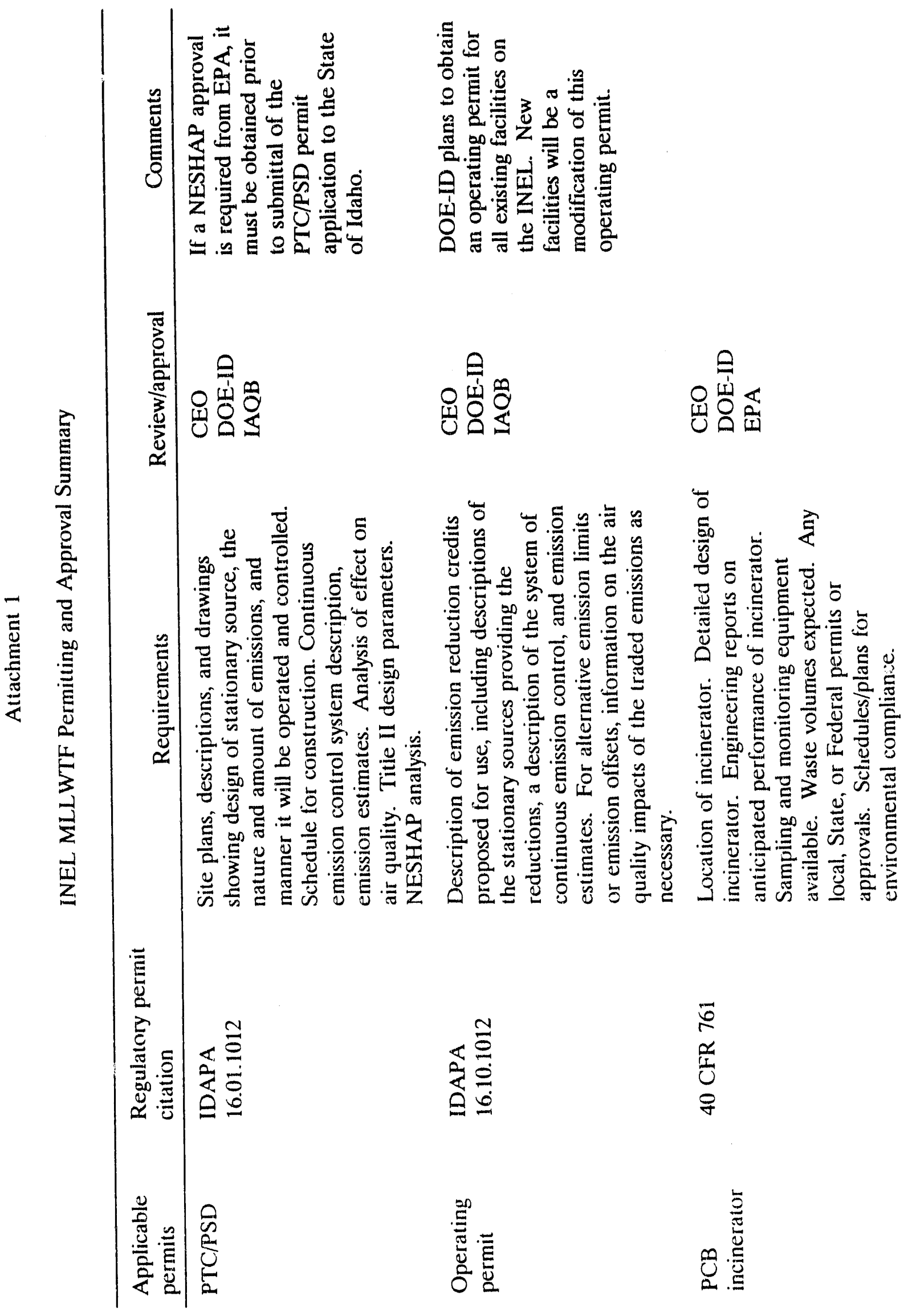




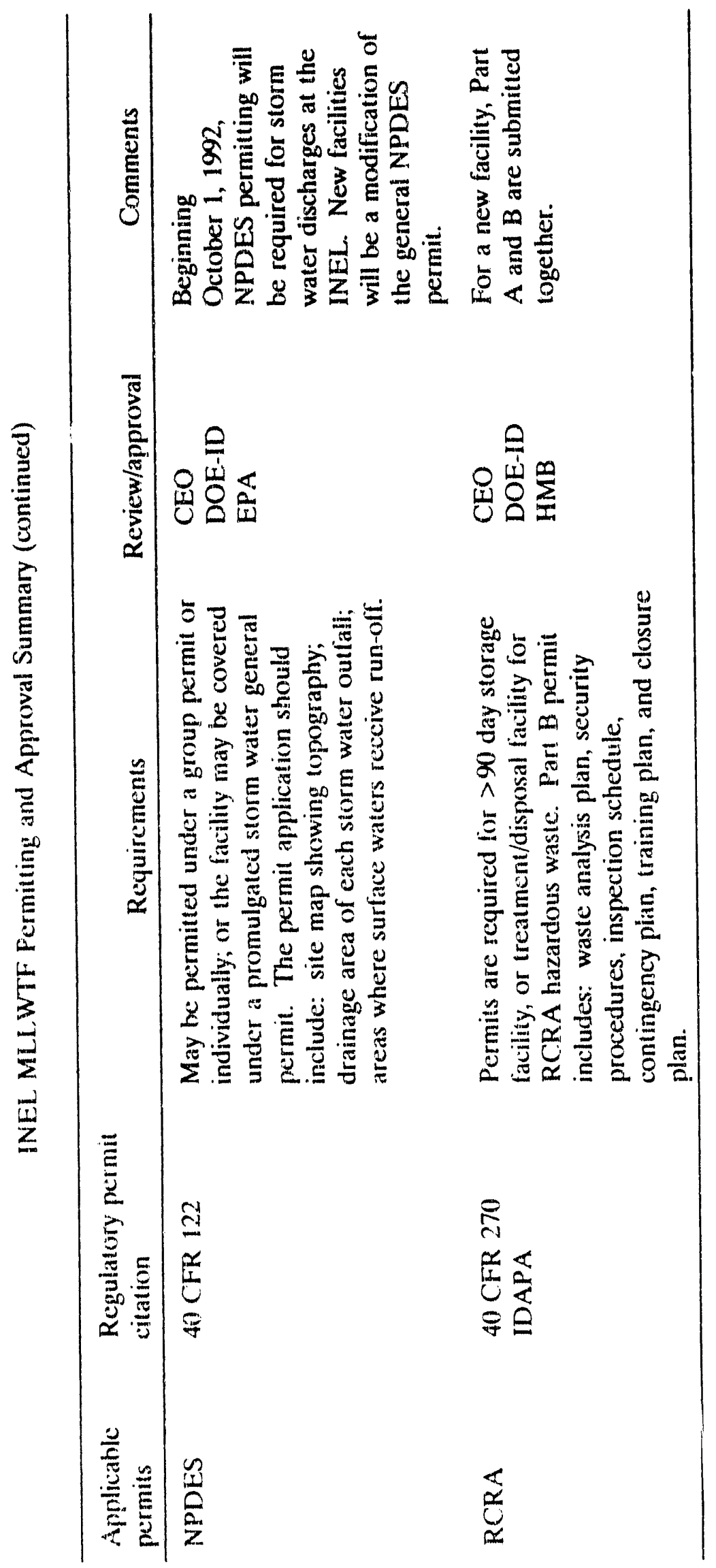




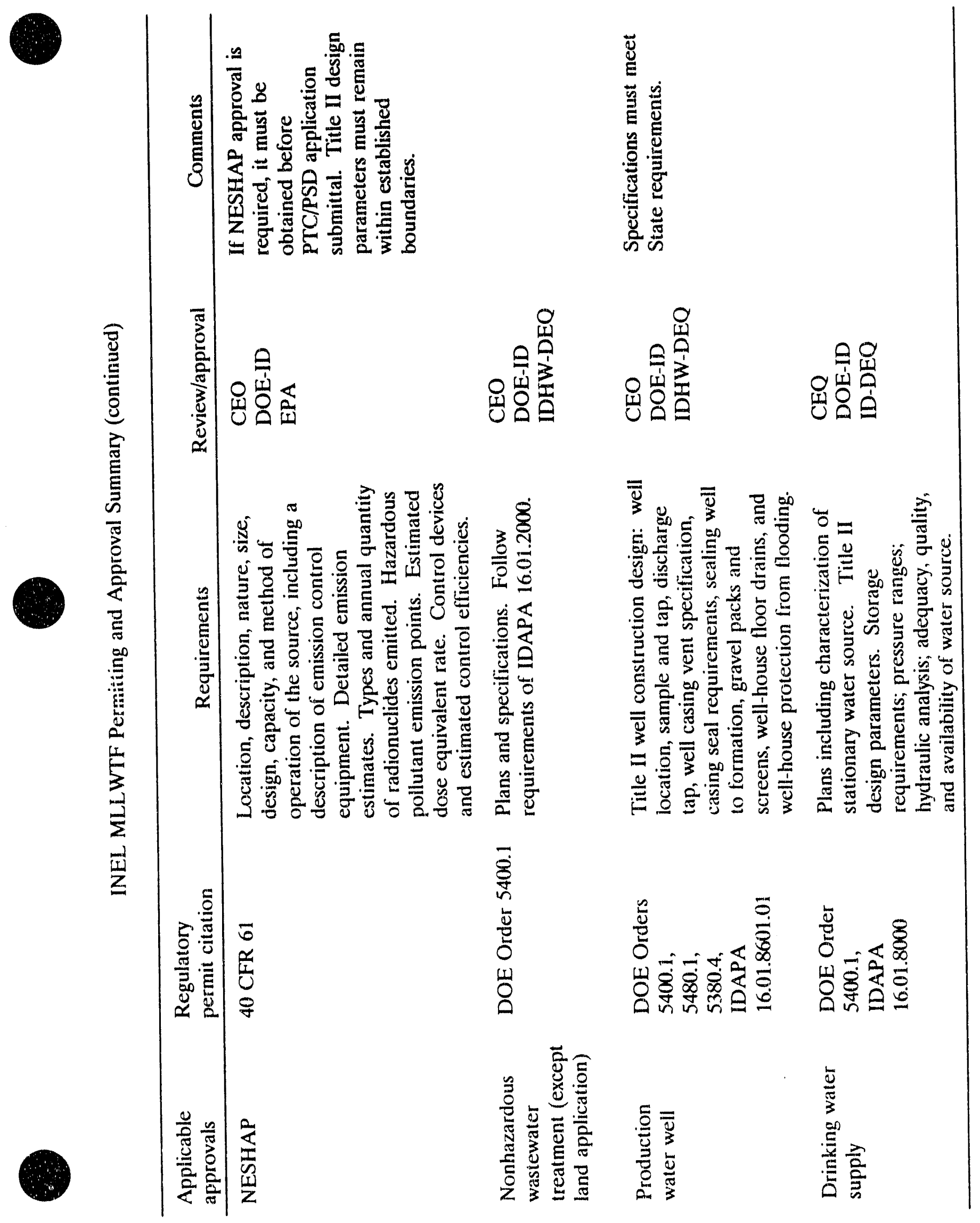


Attachment 2

INEL MLLWTF Environmental Compliance Schedule 


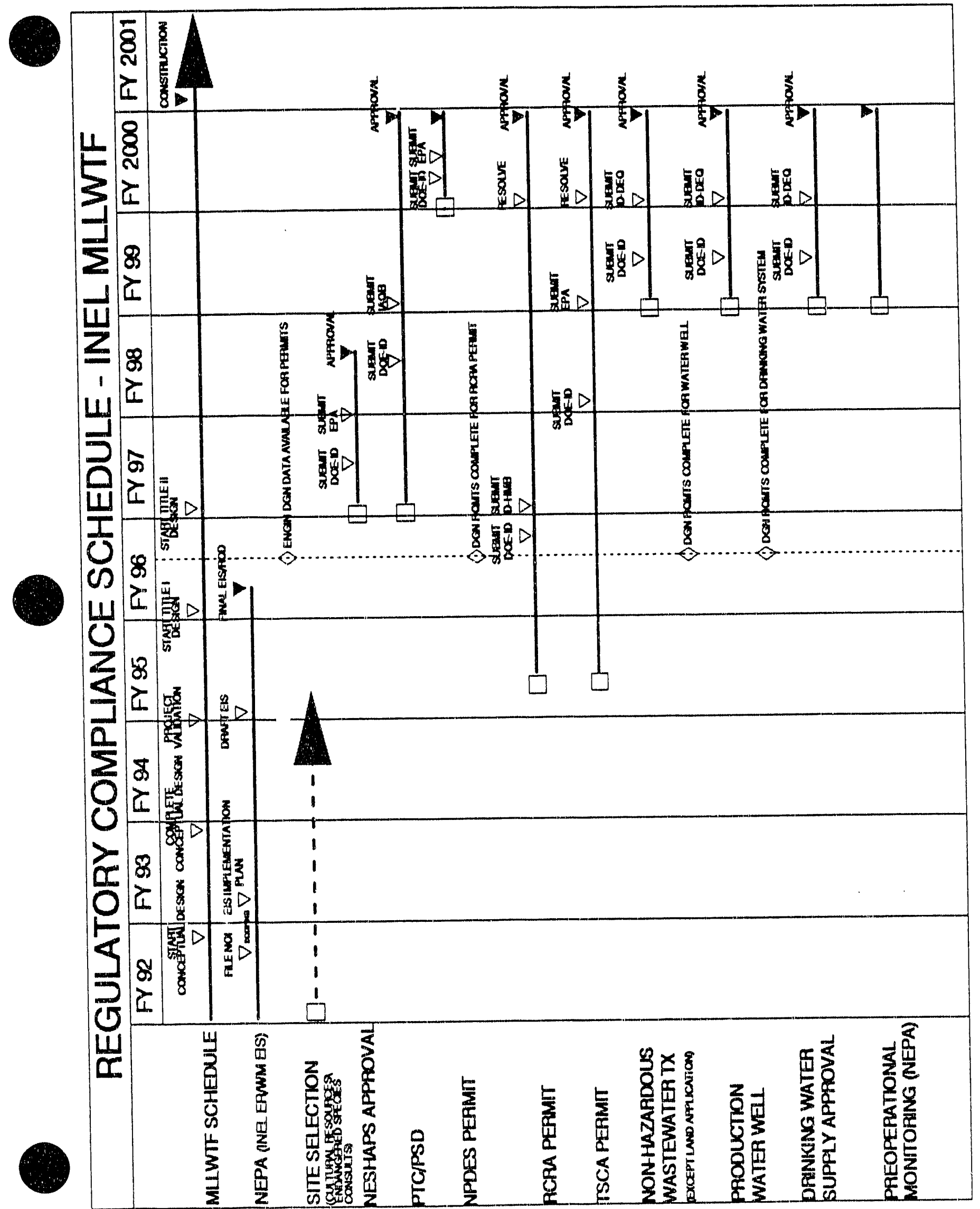




\section{National Environmental Policy Act Requirements, Options, and Recommendations for the Mixed and Low-Level Waste Treatment Facility}

M. J. Jorgenson-Waters

Published March 1992

Idaho National Engineering Laboratory

EG\&G Idaho, Inc.

Idaho Falls, Idaho 83415

Prepared for the

U.S. Department of Energy

Office of Environmental Restoration and Waste Management

Under DOE Idaho Field Offlce

Contract DE-AC07-76ID01570 
$\overline{\bar{z}}$ 


\section{CONTENTS}

ACRONYMS $\ldots \ldots \ldots \ldots \ldots \ldots \ldots \ldots \ldots \ldots \ldots \ldots \ldots \ldots \ldots \ldots \ldots$

DEFINITIONS $\ldots \ldots \ldots \ldots \ldots \ldots \ldots \ldots \ldots \ldots \ldots \ldots \ldots \ldots \ldots \ldots$ vii

1. INTRODUCTION $\ldots \ldots \ldots \ldots \ldots \ldots \ldots \ldots \ldots \ldots \ldots \ldots \ldots \ldots \ldots \ldots$

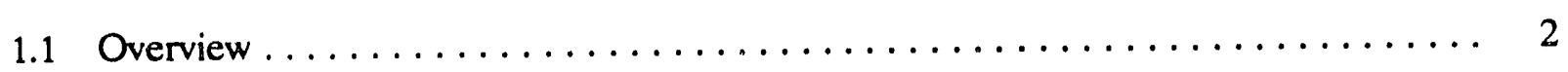

2. FEDERAL STATUTE, REGULATIONS, EXECUTTVE ORDERS, AND DOE

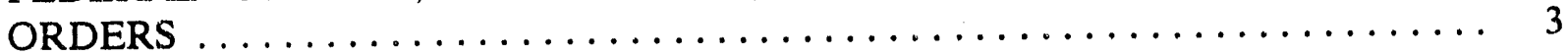

2.1 Atomic Energy Act of 1954, as Amended (42 USC 2011 et seq.) . . . . . . . 3

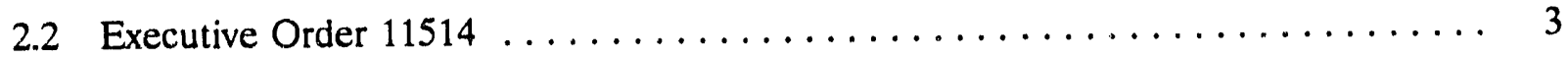

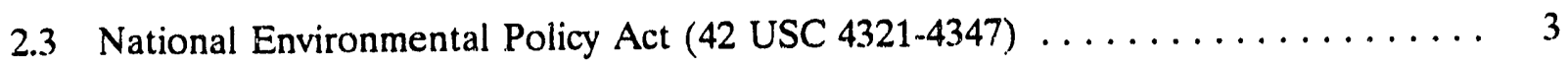

2.3.1 DOE Order 5440.1D. National Environmental Policy Act Compliance Program ............................. 3

2.3.2 DOE-ID Order 5440.1. Implementation of the National Environmental Policy

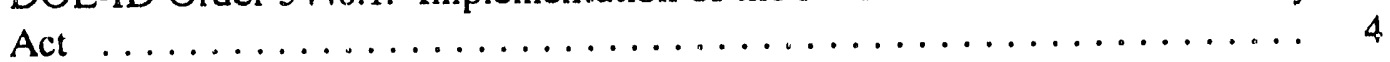

2.3.3 52 FR 47662. DOE Guidelines for NEPA Compliance ........... 4

2.4 DOE Order 4700.1. Project Management System $\ldots \ldots \ldots \ldots \ldots \ldots \ldots \ldots \ldots$

2.4.1 Preoperational Monitoring $\ldots \ldots \ldots \ldots \ldots \ldots \ldots \ldots \ldots \ldots \ldots \ldots$

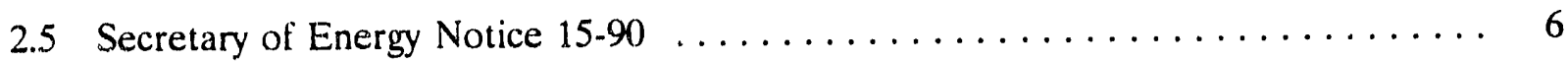

2.6 Environmental Compliance Planning Manual ................. 7

2.7 EG\&G Idaho, Inc. Company Procedures Manual $\ldots \ldots \ldots \ldots \ldots \ldots$

3. NEPA COMPLIANCE FOR THE MLLWTF $\ldots \ldots \ldots \ldots \ldots \ldots \ldots \ldots$

3.1 INEL Environmental Restoration and Waste Management Environmental Impact

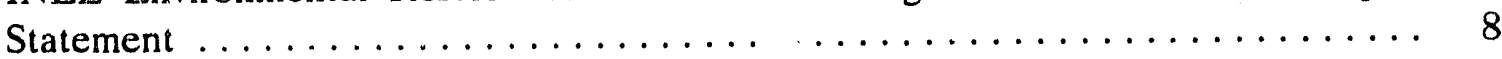

3.2 Project Level Environmental Impact Statement $\ldots \ldots \ldots \ldots \ldots \ldots \ldots \ldots \ldots$

4. CONCLUSION $\ldots \ldots \ldots \ldots \ldots \ldots \ldots \ldots \ldots \ldots \ldots \ldots \ldots \ldots \ldots \ldots$ 
5. RECOMMENDATIONS $\ldots \ldots \ldots \ldots \ldots \ldots \ldots \ldots \ldots \ldots \ldots \ldots \ldots \ldots \ldots \ldots$

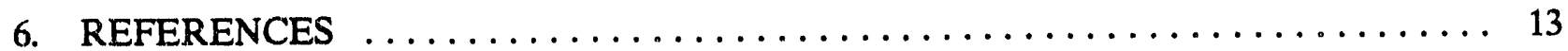

\section{FIGURE}

1. MLLWTF schedule and NEPA compliance options. $\ldots \ldots \ldots \ldots \ldots \ldots \ldots \ldots$ 


\section{ACRONYMS}

ADM

ADS

AEA

CEQ

CFR

CX

DOE-HQs Department of Energy-Headquarters Office

DOE-ID Department of Energy-Idaho Field Office

EA

EC

EIS

$\mathrm{EO}$

EPA

ER

FONSI

FR

FY

HSWA

INEL

IP

LDR

$\mathrm{M} \& \mathrm{O}$

MLLWTF

Action Description Memorandum

Activity Data Sheet

Atomic Energy Act

Council on Environmental Quality

Code of Federal Regulations

Categorical Exclusion

Environmental Assessment

Environmental Checklist

Environmental Impact Statement

Executive Order

Environmental Protection Agency

Environmental Restoration

Finding of No Significant Impact

Federal Register

fiscal year

Hazardous and Solid Waste Amendments

Idaho National Engineering Laboratory

EIS Implementation Plan

Land Disposal Restrictions

managing and operating

Mixed and Low Level Treatment Facility 
NEPA National Environmental Policy Act

NOI Notice of Intent

NRC Nuclear Regulatory Commission

PMS Project Management System

ROD Record of Decision

ROM Rough Order of Magnitude

SD Supplemental Directive

SEN Secretary of Energy Notice

WM Waste Management 


\section{DEFINITIONS}

Action Description Memorandum (ADM). An internal DOE document (normally, not more that 5 pages) containing a concise description of a proposed action and discussion of relevant potential environmental issues, to assist DOE in determining the appropriate level of NEPA document for a proposed action. The time required to prepare an $A D M$ may be 1 to 6 months.

Categorical Exclusion (CX). A category of actions, as defined at 40 CFR 1508.4 and listed in Section D of the DOE NEPA Guidelincs, that do not individually or cumulatively have a significant effect on the human environment and for which neither an environmental assessment (EA) nor an environmental impact statement (EIS) is normally required.

Environmental Assessment (EA). A document, as defined in 40 CFR 1508.9, that assesses whether a proposed action is a "major Federal action significantly affecting the quality of the human environment" and serves as the basis for determining whether to prepare an environmental impact statement or a Finding of No Significant Impact (FONSI). An EA is normally a brief document of 10 to 15 pages in length and may take one year to prepare.

Environmental Checklist (EC). DOE-ID Form \# ID 5440.1A. An EC is a checklist (worksheet) filled out to begin assessing the environmental effects, if any, of the project/program. The EC initiates the NEPA process.

Environmental Impact Statement (EIS). A document, as defined in 40 CFR 1508.11, and prepared in accordance with the requirements of section 102(2)(C) of NEPA, the CEQ Regulations, and the DOE NEPA Guidelines. An EIS provides a detailed assessment of the significant environmental impacts of a proposed federal action. It must include reasonable alternatives to the proposed action and must assess the environmental and social impacts of each alternative. An EIS can require two to four years and anywhere from $\$ 10,000$ to $\$ 10,000,000$ to prepare depending on the complexity of the project, availability of the data, and the degree of public controversy associated with the project.

EIS Implementation Plan (IP). A brief written plan that provides guidance for the preparation of a DOE EIS (including a supplemental EIS). The plan records the results of the scoping process and outlines the procedures by which an EIS is to be prepared.

Finding of No Significant Impact (FONSI). A document, as defined in 40 CFR 1508.13, prepared to record a departmental decision that the environmental impacts of an action considered in an EA will not have a significant effect on the human environment and that an EIS is not required for the proposed action.

Interim Action. An action that is within the scope of an ongoing EIS and that DOE proposes to take before issuing a record of decision, and that is permissible under 40 CFR 1506.1.

Major Federal Action. Actions, as defined in 40 CFR 1508.18, with effects that may be major and which are potentially subject to Federal control and responsibility. 
NEPA Document. An EA, FONSI, notice of intent to prepare an EIS, EIS, record of decision, categorical exclusion determination, or any other document prepared pursuant to DOE Order 5100.3.

Notice of Intent (NOI). A document, defined at 40 CFR 1508.22, that announces the intent to prepare an EIS for a proposed action.

Record of Decision (ROD). A document prepared in accordance with the requirements of $40 \mathrm{CFR}$ 1505.2 , that provides a concise public record of the decision on a proposed action for which an EIS was prepared, and identifies the alternatives considered in reaching the decision, the environmentally preferable alternative(s), factors considered in making the decision, whether all practicable means to avoid or minimize environmental harm have been adopted, and if not, why they were not.

Site-wide NEPA Document. A broad-scope EIS or EA that identifies and assesses the individual and cumulative impacts of the continuing and reasonably foreseeable future actions at a multifacility DOE site; it may also refer to an associated site-wide NEPA document such as an NOI, ROD, or FONSI.

Supplemental EIS. An EIS prepared to supplement a prior EIS, as provided in 40 CFR 1502.9(c).

Treatment. Any method, technique, or process designed to change the physical or chemical character of waste to render it less hazardous, safe to transport, store, or dispose of, or reduce in volume (DOE Order 5820.2A). Any method, technique, or process, including neutralization, designed to change the physical, chemical, or biological character or composition of any hazardous waste so as to neutralize such waste, or so as to recover energy or material resources from the waste, or so as to render such waste non-hazardous, or less hazardous; safer to transport, store, or dispose of; or amenable for recovery, amenable for storage, or reduced in volume (40 CFR 261.10). 


\section{National Environmental Policy Act Requirements, Options, and Recommendations for the Mixed and Low-Level Waste Treatment Facility}

\section{INTRODUCTION}

An important part of the Department of Energy-Idaho Field Office (DOE-ID) waste management mission is to identify, evaluate, develop, and utilize technologies designed to minimize, and/or dispose of hazardous, radioactive, and mixed waste, and for remediation and restoration of previous disposal sites in an effort to protect human health and the environment. Inherent in this mission is the development and implementation of treatment technologies to reduce the toxicity, mobility, and/or volume of the various contaminants in the waste generated and stored at the Idaho National Engineering Laboratory (INEL).

Currently, 33 percent of the low-level waste volume generated at the INEL is disposed in an untreated waste form. This waste represents over 99 percent of the total curie content of the lowlevel waste inventory. Presently, no capability exists at the INEL to treat this portion of the waste.

INEL mixed wastes are subject to Land Disposal Restrictions (LDRs) which are promulgated in the Hazardous and Solid Waste Amendments (HSWA) to the Resource Conservation and Recovery Act (RCRA). LDR requirements prohibit the storage of hazardous waste except for "the purpose of the accumulation of such quantities of hazardous waste as necessary to facilitate proper recovery, treatment, or disposal" (40 CFR 268.50). DOE-ID is negotiating a compliance agreement with the State of Idaho and the Envir onmental Protection Agency (EPA) to resolve issues for the management of mixed waste. The agreement is designed to facilitate the development of treatment processes for the LDR mixed wastes.

DOE-ID proposes to site, construct, and operate a Mixed and Low Level Waste Treatment Facility (MLLWTF) at the INEL. The facility is intended to provide the required treatment for INEL generated mixed and low-level waste in accordance with EPA, State, and DOE regulations.

The MLLWTF will be designed to treat beta-gamma contaminated mixed and low-level wastes in accordance with applicable regulations governing the treatment of these waste types. The treatment for these wastes will be designed to produce a stabilized waste form which will significantly reduce environmental impacts. This activity will provide enhanced and expanded treatment capabilities for mixed and low-level wastes generated during environmental restoration activities and newly generated wastes, for the treatment of high-activity mixed and low-level waste (class B and C), and for the treatment of the low-activity mixed and low-level waste (class A). Treatment will also be provided for contaminated lead, sludges, resins, pyrophorics, and other troublesome mixed low-level wastes. The possibility for melting classified metals will be included. 


\subsection{Overview}

This report has been prepared to outline the National Environmental Policy Act (NEPA) requirements and options for the MLLWTF. The report includes a discussion of the federal statutes, regulations, executive orders, and DOE orders implementing NEPA as well as the documentation, and processes, required for NEPA compliance during the design phases of the proposed facility.

This report does not attempt to encompass all relevant federal and state environmental requirements and statutes such as the Clean Air Act, Clean Water Act, and the Endangered Species Act. A comprehensive environmental compliance plan and schedule for the MLLWTF project, is scheduled for completion in February, 1992, and will include an evaluation of the proposal for compliance with applicable environmental laws. 


\section{FEDERAL STATUTE, REGULATIONS, EXECUTIVE ORDERS, AND DOE ORDERS}

Projects at the INEL must comply with the applicable environmental federal statutes, regulations, executive orders (EO), DOE orders and guidelines that provide for protection of public health and the environment.

\subsection{Atomic Energy Act of 1954, as Amended (42 USC 2011 et seq.)}

The Atomic Energy Act of 1954 (AEA) authorized DOE to establish standards to protect health or minimize dangers to life or property. In accordance with the Energy Reorganization Act of 1974, DOE defense-related operations are not subject to licensing by the Nuclear Regulatory Commission (NRC). DOE has established an extensive system of standards and requirements through its orders to ensure safe operation of its facilities. Compliance with these orders is mandatory for federal facility managing and operating $(\mathrm{M} \& O)$ contractors, such as EG\&G.

\subsection{Executive Order 11514}

EO 11514, as amended by EO 11991, requires federal agencies to monitor and control their activities on a continuing basis to protect and enhance the quality of the environment. In addition, federal agencies are to develop procedures to ensure the fullest practicable provision of timely public information and understanding of federal plans and programs which may result in environmental impacts in order to obtain the views of interested parties. EO 11991 of May 24, 1977, directed the Council on Environmental Quality (CEQ) to issue regulations implementing the procedural provisions of NEPA. Accoldingly, the CEQ issued these NEPA regulations in 40 CFR 1500 to 1508 on November 29, 1978.

Several DOE orders and guidelines adopt NEPA and the CEQ guidelines as DOE policy. The MLLWTF project will proceed in accordance with these guidelines.

\subsection{National Environmental Policy Act (42 USC 4321-4347)}

All potential projects involving any federal agency must undergo a review pursuant to NEPA to identify and evaluate potential environmental impacts. NEPA constitutes a national policy to protect the environment and to promote a better understanding of the ecological systems and natural resources important to the nation. The CEQ regulations implementing NEPA contain "actionforcing" provisions to ensure that federal agencies consider environmental information prior to making decisions on proposed actions. The NEPA process includes decision points at which the significance of environmental effects are considered, project alternatives are identified, and appropriate mitigation measures are identified and adopted.

\subsubsection{DOE Order 5440.1D. National Environmental Policy Act Compliance Program}

DOE Order 5440.1D describes the roles of various DOE offices in implementing NEPA. It also states that it is DOE's policy to comply fully with the letter and spirit of NEPA. To ensure that ervironmental factors are considered in the decision making process and to promote environmentally 
responsible decisions, DOE will incorporate NEPA requirements early in the planning process for proposed actions. DOE also will coordinate its NEPA activities with the states that host DOE facilities. DOE is committed to complete assessment and full disclosure of the environmental consequences of its proposed actions.

\subsubsection{DOE-ID Order 5440.1. Implementation of the National Environmental Policy Act}

DOE-ID Order 5440.1 is a Supplemental Directive (SD) establishing the DOE-ID authorities, responsibilities, local guidance, and local direction for implementation of DOE Order 5440.1D. This order states DOE-ID contractors shall:

- Provide technical support and information necessary for DOE's use in making NEPA documentation determinations

- Prepare and submit draft CX determinations, ADMs, and EAs to DOE-ID for review and approval and they shall also provide information needed to prepare EISs applicable to DOE technical support contractors

- Prepare draft impact review analyses to support the project manager/program directors' determination of whether supplemental EISs should be prepared

- Establish internal procedures and records to ensure that environmental factors are adequately considered along with other program considerations in the decision-making process

- Participate, as requested by DOE-ID, in scoping meetings and public hearings

- Review company activities and proposals and ensure appropriate recommendations are made on the level of NEPA documentation required for proposed actions.

\subsubsection{FR 47662. DOE Guidelines for NEPA Compliance}

The DOE NEPA guidelines, 12-15-87 (52 FR 47662) as amended 3-27-89 (54 FR 12474) and 9-7-90 (55 FR 37174), establish guidelines for implementing the procedural provisions of NEPA pursuant to the CEQ Regulations.

Proposed revisions to the DOE NEPA guidelines were published in the Federal Register (FR) on November 2, 1990 and ais expected to be final the end of calendar year 1991. Subpart D, of the DOE NEPA guidelines, provide requirements and guidance for determining the appropriate level of NEPA review for proposed DOE actions, and establish criteria for determining the eligibility of specific actions for categorical exclusion. Four appendices to subpart D set forth the classes of actions that normally would be categorically excluded from preparation of an EIS or an EA (appendices $\mathrm{A}$ and $\mathrm{B}$ ), actions that normally require preparation of an EA but not necessarily and EIS (appendix C), and actions that normally require preparation of an EIS (appendix D).

Appendix C to Subpart D, Classes of Actions that Normally Require EAs but Not Necessarily $E I S s$, includes major projects in the class of actions normally requiring an EA. Appendix D to 
Subpart D, Classes of Actions that Normally Require EISs, includes major system acquisitions in the class of actions normally requiring an EIS. The following matrix shows the DOE criteria for designation of a system or project as a major project or a major system acquisition as defined in DOE Order 4240.1J, Designation of Major System Acquisitions and Major Projects.

Included in the class of actions normally requiring an EIS are activities involving the siting, construction, and operation of incinerators, other than research and development incinerators or incinerators for nonhazardous solid waste (as designated in 40 CFR 261.4(b)).

The proposed MLLWTF project would result in the construction and operation of a large scale project. Activity Data Sheet 5E-2 lists the Rough Order of Magnitude (ROM) cost for the MLLWTF facility at $\$ 125$ million dollars. Candidate treatment processes for the MLLWTF include a high temperature incineration type process designed to process combustible wastes and destroy hazardous waste constituents. The proposed action would be considered to be a "major federal action" with effects that might be significant and that are potentially subject to federal control and responsibility. The MLLWTF would, therefore, most likely require preparation of an EIS.

NEPA documentation is required to ensure that environmental concerns are addressed during project planning and decision making. Because detailed design (Title II design for DOE projects) and construction cannot begin until the NEPA process is complete (in accordance with the INEL Environmental Compliance Planning Manual, p.I-6 and the EG\&G Environmental Compliance Manual, Section A-6), NEPA documentation requirements are addressed in this report.

\begin{tabular}{llc}
\hline Project categories & \multicolumn{1}{c}{ DOE criteria } & Level of NEPA review \\
\hline Major projects & $\begin{array}{l}\text { Considers importance of the } \\
\text { project, project objectives, } \\
\text { and size and complexity of } \\
\text { the project; degree of DOE } \\
\text { control required; visibility of } \\
\text { the project; potential severity } \\
\text { of environmental impacts; and } \\
\text { clarity and stability of the } \\
\text { project. These projects have } \\
\text { total project costs between } \\
\text { \$50 million and \$100 million. } \\
\text { Considers national urgency, } \\
\text { importance, size, complexity, } \\
\text { and dollar value. These } \\
\text { systems have total project } \\
\text { costs or estimated } \\
\text { Government share costs in } \\
\text { excess of } \$ 100 \text { million. }\end{array}$ \\
\hline
\end{tabular}




\subsection{DOE Order 4700.1. Project Management System}

DOE Order 4700.1 establishes the DOE project management system and provides implementing instructions, formats, and procedures, and sets forth the principles and requirements which govern the development, approval, and execution of DOE's outlay program acquisitions as embodied in the project management system (PMS). Compliance with this order is a requirement for all project personnel (EG\&G Project Management Manual).

Part F of DOE Order 4700.1, Environmental Planning and Review, integrates environmental planning and review into the project management system and serves as a guideline for consideration of environmental factors that need to be considered in program planning. The order gives attention to environmental requirements and the integration of NEPA.

\subsubsection{Preoperational Monitoring}

DOE Order 5400.1, General Environmental Protection Program, specifies that preoperational monitoring activities should begin at least one year, and preferably two years, before start-up to adequately cover seasonal changes. The activities are required to be complete before start-up of the new facility. The preoperational monitoring activities shall:

- Characterize existing physical, chemical, and biological conditions that could be affected

- Establish background levels of radioactive and chemical components

- Characterize pertinent environmental and ecological parameters

- Identify potential pathways for human exposure or environmental impact as a basis for determining the nature and extent of the subsequent routine operational and emergency effluent monitoring and environmental surveillance programs.

Chapter IV, Part 3 of 5400.1 describes general guidance on baseline data collection. Some of the data reported for NEPA compliance may also satisfy requirements. Past and present monitoring programs at th? INEL will provide much of the needed baseline data for the MLLWTF project. Additional studies may be required to summarize and evaluate data applicable to the MLLWTF project and to expand the database on specific pollutants which will be released by MLLWTF operations.

\subsection{Secretary of Energy Notice 15-90}

On June 27, 1989, the Secretary of Energy announced a ten-point initiative to ensure that all DOE activities are carried out in full compliance with the letier and spirit of environmental statues and regulations. In order to implement this initiative as it relates to NEPA, Secretary of Energy Notice (SEN) 15-90 was issued on February 5, 1990. SEN-15-90 contains the latest DOE position on NEPA compliance activities. This notice identifies changes in DOE NEPA processes, requires formal involvement of the states in document review, and defines appr sval authorities. In particular, SEN-15-90 directs that the DOE NEPA guidelines be revised to include: 
- A new agency policy for developing and updating site-wide NEPA documents (a site-wide NEPA document is defined as a broad-scope EIS or EA that identifies and assesses the individual and cumulative impacts of the continuing and reasonably foreseeable future actions at a DOE site)

- A revised and expanded list of categorical exclusions formulated to minimize the need for subjective judgment

- The elimination of a DOE document generally referred to as a NEPA "memorandum-totile," which DOE has used to document a determination (other than a categorical exclusion) that neither an EIS nor and EA is required for a proposed action

- A requirement that DOE hold public scoping meetings for all EISs and public hearings for all draft EISs

- Provisions for the public availability of all EIS implementation plans and all analyses made to determine whether a supplement to an EIS is required

- Provisions for notifying states of determinations to prepare an EA or an EIS for all proposed DOE projects in the states

- Provisions allowing states an opportunity to comment on EAs for proposed DOE projects in the state prior to DOE approval of the EA.

These changes are reflected in the proposed rules to the DOE NEPA guidelines.

\subsection{Environmental Compliance Planning Manual}

The Environmental Compliance Planning Manual at the INEL, DOE/ID-10166, Rev. 3, 4/91 includes additional information on compliance with NEPA and other environmental regulations.

\subsection{EG\&G Idaho, Inc. Company Procedures Manual}

The EG\&G Idaho, Inc. Company Procedures Manual, Section 8.5, Preparation and Approval of NEPA Documentation, provides general information and instructions to integrate requirements of NEPA into all EG\&G Idaho facility and/or program planning as early as possible in the project planning process. 


\section{NEPA COMPLIANCE FOR THE MLLWTF}

In accordance with the requirements of NEPA, DOE Order 5440.1D, Regulations for Implementing the Procedural Provisions of NEPA (40 CFR 1500 to 1508), DOE NEPA guidelines, Secretary of Energy Notice SEN-15-90, and appropriate implementing DOE-ID orders, environmental documentation is being prepared for the MLLWTF project.

\subsection{INEL Environmental Restoration and Waste Management Environmental Impact Statement}

The INEL strategy for compliance with NEPA includes preparation of a programmatic or dualpurpose programmatic and project-specific EIS to address existing and planned environmental restoration (ER) and waste management (WM) activities. The EIS scope includes existing and conceptually planned ER and WM programs, facilities and activities, analyses of the environmental risks of each program and cumulative impacts (Activity Data Sheet (ADS) 76-E1). The INEL ER and WM EIS scope excludes reactor operations and any research activities not pertaining to ER and WM. This activity will aid in satisfying the DOE site-wide EIS policy requirement presented in SEN-15-90 and proposed NEPA implementing rules. Provisions have been made to encompass the proposed MLLWTF in this INEL ER and WM EIS.

A third party has negotiated a contract with DOE to prepare the INEL ER and WM EIS. A Notice of Intent (NOI) has been drafted and is currently in review at DOE-ID. Following review and approval, the NOI will be published in the Federal Register, initiating the scoping process and the period of public involvement. The INEL ER and WM EIS is scheduled to be scoped and defined near the end of fiscal year (FY) 1992. The scoping process may indicate that the scope of the INEL ER and WM EIS is too large and unmanageable as proposed. In this event a project specific EIS may be necessary for the MLLWTF.

Waiting to submit the required environmental documentation (EC and/or $A D M$ ) could cause a delay in the MLLWTF project schedule by delaying the EIS process. A ripple effect is generated when preparation of the EIS is delayed. In many instances the permitting authority will not commence review of permit applications until a draft EIS, as a minimum, has been circulated. As a result, the permitting process is no longer controlled by the availability of design information, but instead by the availability of the draft EIS. This delays the start of construction and makes the EIS and other environmental review processes critical path items. Any delays in these processes will further delay the project. (DOE Order 4700.1)

\subsection{Project Level Environmental Impact Statement}

An alternative to including the MLLWTF project in the INEL ER and WM EIS would be to prepare a project level EIS. This alternative would require concurrence from DOE-ID and DOE-HQ prior to submitting the appropriate environmental documentation (EC and/or ADM) to DOE for formal class determination. 
Figure 1 shows a logic diagram for the INEL ER and WM EIS process and a proposed project level EIS in relation to the project schedule for the MLLWTF. Delays in the NEPA process could impact the start of Title II design and ultimately construction and operation of the facility.

A project level EIS would focus on a single activity which is describable, manageable, and less likely to impact the project schedule. However, the facility operations must tie in to other activities at the INEL and the combined and cumulative impacts at the INEL need to be considered.

A project level EIS would require negotiating a contract with a third party for preparation. It is a CEQ requirement to subcontract the preparation and writing $f f$ an EIS to a third party to prevent conflict of interest or the appearance thereof between field offices and contractors at the work locations. Field offices and contractors may assist in providing technical information and review.

Regardless of whether the MLLWTF is encompassed in the INEL ER and WM EIS or in a project level EIS, it should be noted that additional environmental documentation will need to be submitted for the following project interim activities:

- Site characterization (sampling and/or geophysical work conducted during the site selection process)

- Preoperational monitoring

- Cold mock-ups and bench scale testing.

Environmental documentation for these interim activities should be submitted in accordance with the Environmental Compliance Planning Manual (DOE/ID-10166, Revision 3, 4/91) and EG\&G Idaho Company Procedure 8.5, Preparation and Approval of NEPA Documentation. 


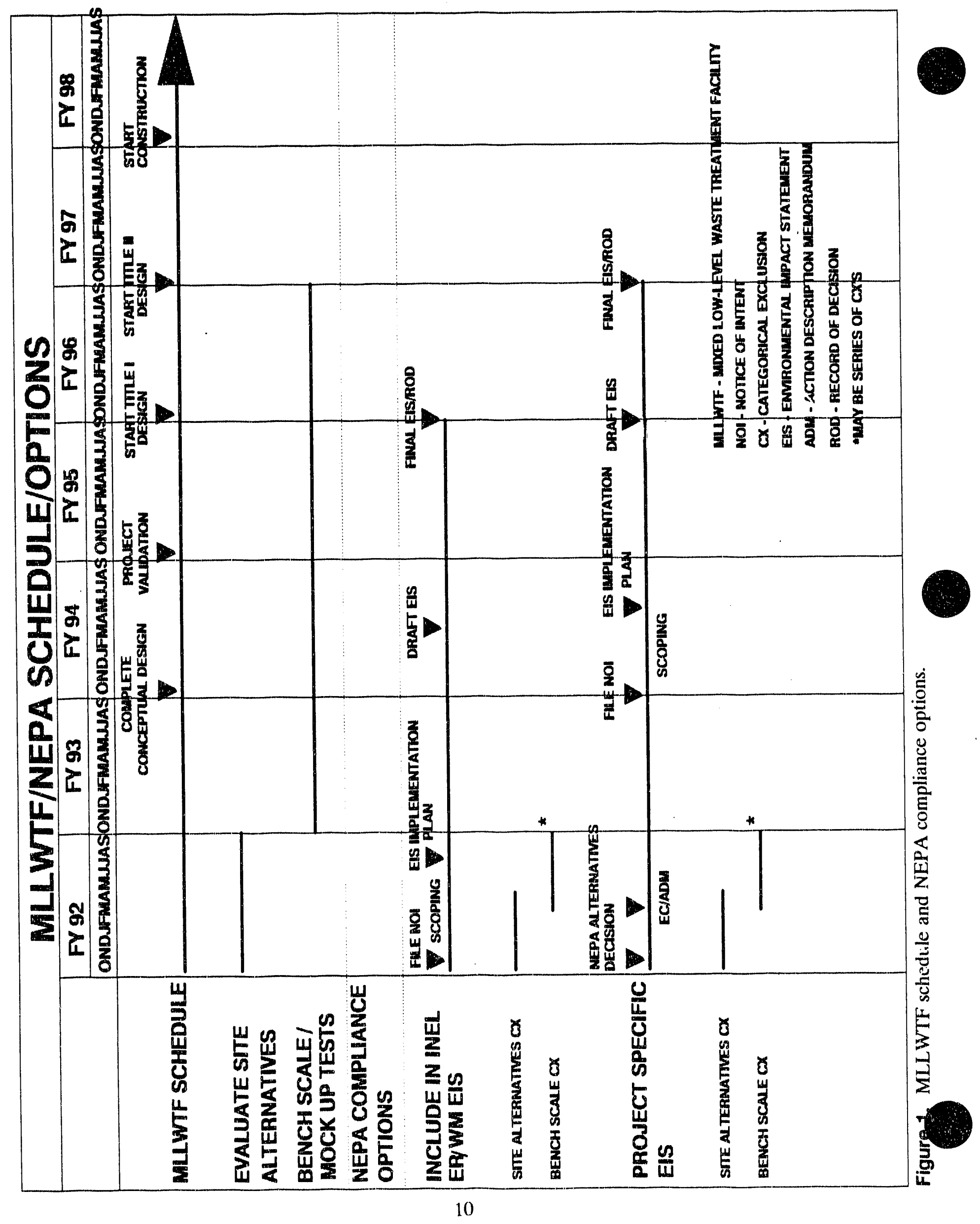




\section{CONCLUSION}

Proper environmental planning is critical to project management. For a given project effort, a number of environmental requirements may be applicable, and compliance planning may involve complex tradeoffs of time, risk, costs, and quality. Failure to properly comply with environmental regulations and statutes invites lawsuits, delays, and loss of resources.

For now one can conclude that environmental planning and NEPA compliance for the MLLWTF is encompassed in the INEL ER and WM EIS. However, the scope of the EIS is large and may be unmanageable ultimately requiring preparation of a project level EIS for the MLLWTF. Activities needed to support the preparation of an EIS include:

- Identification of waste streams and definition of source terms

- Waste treatment tradeoff studies and identification of candidate treatment processes

- Hazard/risk assessments

- Evaluation of siting criteria

- Development of conceptual design.

An alternative to including the MLLWTF in the INEL ER and WM EIS would be preparation of a project level EIS. The scope of a project level EIS would be describable, manageable, and less likely to impact project schedule. However, this alternative would require concurrence from DOE-ID and DOE-HQ prior to submitting any environmental documentation to DOE for formal class determination. 


\section{RECOMMENDATIONS}

To avoid delays impacting the design and construction of the MLLWTF, an evaluation of the NEPA compliance options in relation to the project schedule and requirements needs to be conducted and a timely decision made. This NEPA alternatives decision process should determine the best approach to environmental compliance for the MLLWTF.

It is recommended that the MLLWTF NEPA compliance options and project schedule be discussed with DOE-ID and the best approach to environmental compliance selected. The selected approach should have DOE-HQ concurrence prior to submitting any environmental documentation.

Should it be determined that the MLLWTF be encompassed in the INEL ER and WM EIS, EC's for the project interim activities listed in Section 3.2 need to be prepared and submitted to the Environmental Assessment and Permitting Unit of EG\&G for review and a NEPA documentation determination. The activities listed in Section 4.0 of this report should be conducted to support the INEL ER and WM EIS.

Should it be determined that the best approach to NEPA compliance for the MLLWTF be preparation of project level NEPA documentation, an EC and/or an ADM should be prepared as soon as possible and submitted to the Environmental Assessment and Permitting Unit of EG\&G for review and a NEPA documentation determination. 


\section{REFERENCES}

1. DOE Order 5400.1, General Environmental Protection Program.

2. DOE Order 5440.1D, Implementation of the National Environmental Policy Act.

3. DOE-ID Order 5440.1, Implementation of the National Environmental Policy Act.

4. DOE/ID-10166, Environmental Compliance Planning Manual at the Idaho National Engineering Laboratory, Rev 3, 4/91.

5. DOE Order 5820.2A, Radioactive Waste Management, 9/88.

7. 52 FR 47662, DOE Guidelines for NEPA Compliance.

8. 55 FR 37172, Amendments to DOE Guidelines for NEPA Compliance.

9. 40 CFR 1500-1508, CEQ Regulations.

10. SEN-15-90, Secretary of Energy Notice, National Environmental Policy Act.

11. 42 USC 4321-4347, National Environmental Policy Act.

12. EG\&G Idaho Company Procedure 8.5, Preparation and Approval of NEPA Documentation.

13. EG\&G Environmental Manual, Section A-6, NEPA Compliance.

14. EG\&G Project Management Manual, Project Management Overview.

15. Federal Register, 10 CFR Part 1021, National Environmental Policy Act Implementing Procedures; Proposed Rule, November 2, 1990.

16. K. S. Murthy, CRC National Environmental Policy Act (NEPA) Process, CRC Press, 1988. 


\section{Regulatory Justification for the Treatment of Mixed and Low-Level Waste at the Idaho National Engineering Laboratory}

Deborah J. Kufen

Published March 1992

Idaho National Engineering Laboratory

EG\&G Idaho, Inc.

Idaho Falls, Idaho 83415 
○

○ 


\section{SUMMARY}

The Department of Energy (DOE) generates significant amounts of mixed and low-level waste at the Idaho National Engineering Laboratory (INEL). DOE facilities are required to manage their radioactive wastes in accordance with DOE orders developed to carry out the authority granted by the Atomic Energy Act (AEA). Hazardous wastes must be managed in compliance with regulations promulgated by the U.S. Environmental Protection Agency (EPA). It is the policy of the DOE, as stated in DOE 5400.3, "Hazardous and Radioactive Mixed Waste Program," to manage all departmental hazardous and radioactive mixed wastes according to the requirements of Subtitle $C$ of the Resource Conservation and Recovery Act (RCRA), and the AEA, respectively. RCRA applies to the extent that it is not inconsistent with the AEA.

The radioactive component of mixed waste is subject to the requirements of DOE $5820.2 \mathrm{~A}$, "Radioactive Waste Management." This order provides for treating low-level wastes to ensure that the disposal facilities will meet the acceptable performance objectives. This order also mandates that low-level waste be managed on a systemic basis using a combination of waste reduction, segregation, treatment, and disposal practices to maximize the overall system cost effectiveness.

The Hazardous and Solid Waste Amendments (HSWA) of 1984, through the land disposal restrictions (LDR), prohibit disposal of hazardous and mixed wastes that have not been treated to standards required by the EPA in 40 CFR 268. These prescribed treatments either eliminate a hazardous characteristic or yield a treated residue with acceptably low concentrations of hazardous constituents. Different approaches are taken in establishing treatment standards for these land disposal restricted wastes. The EPA either identifies a specific treatment technology for a particular waste, or designates a maximum concentration level for regulated constituents which can be achieved by any technology. The HSWA directed EPA to establish treatment standards for each of the seven groups of RCRA hazardous wastes by specific dates. These dates, referred to as statutory deadlines, will eventually restrict land disposal of all RCRA hazardous and mixed waste.

DOE regulations permit LDR wastes to be stored until radionuclides decay to a level at which they can be disposed of by approved methods. However, the HSWA amendments prohibit iny storage of a land disposal restricted waste unless the storage is for the sole purpose of accumulating sufficient quantities in a tank or container to facilitate proper recovery, treatment, or disposal of that waste (40 CFR 268.50). Therefore, storage of restricted wastes is prohibited after the statutory deadlines, and is a direct violation of the law.

Low-level waste is generally subjected to treatment to reduce the volume of waste requiring disposal, to change the waste form, and to separate the radioactive components from the nonradioactive components in the waste stream. Low-level waste treatment takes place when it is necessary to satisfy regulatory requirements or if it improves the overall cost effectiveness of disposal. Increased social awareness of waste management practices, as well as DOE's responsibility to the public for managing its waste and protecting human health and the environment are subsequent reasons for treatment.

The priority rationale for the treatment of mixed waste is the avoidance of impacts (including fines) for the violation of EPA/state regulations and agreements. Mixed waste is subjected to 
treatment to diminish the toxicity of the waste or substantially reduce the likelihood of migration of hazardous constituents from the waste by meeting the standards specified in the land disposal restrictions. At this time, California List (4C CFR 268.32), spent solvent ( 40 CFR 268.30), and dioxin (40 CFR 268.31) containing mixed wastes are being stored out of compliance with the storage prohibitions under 40 CFR 268 . When the national capacity variance expires on May 8,1992 , all third-third mixed wastes will be prohibited from storage unless treatment capabilities are in place to process these mixed waste streams. An exception would be if an extension is granted on a case-bycase basis. Additionally, the disposal of wastes that have not been treated to the standards required by the EPA in the land disposal restrictions will also be prohibited. 


\section{CONTENTS}

SUMMARY $\ldots \ldots \ldots \ldots \ldots \ldots \ldots \ldots \ldots \ldots \ldots \ldots \ldots \ldots \ldots \ldots \ldots \ldots \ldots \ldots \ldots$

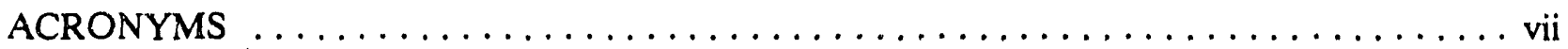

1. AUTHORITY $\ldots \ldots \ldots \ldots \ldots \ldots \ldots \ldots \ldots \ldots \ldots \ldots \ldots \ldots \ldots \ldots$

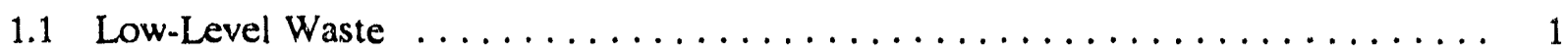

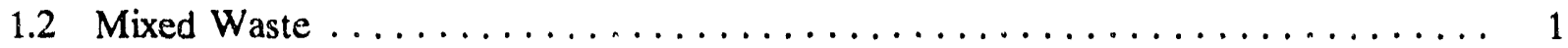

2. REGULATORY REQUIREMENTS FOR LOW-LEVEL WASTE $\ldots \ldots \ldots \ldots \ldots$

2.1 Department of Energy (DOE) Orders $\ldots \ldots \ldots \ldots \ldots \ldots \ldots \ldots \ldots \ldots \ldots$

2.1.1 DOE 5820.2A Radioactive Waste Management $\ldots \ldots \ldots \ldots \ldots \ldots \ldots 2$

2.1.2 DOE 5400.1 General Environmental Protection Program ........... 2

2.2 The Atomic Energy Act (AEA) of 1954, as Amended (42 USC 2011 et seq.) . . . . 2

2.2.1 Environmental Protection Agency $(\mathrm{EPA}) \ldots \ldots \ldots \ldots \ldots \ldots \ldots$

2.3 The Low-Level Radioactive Waste Policy Amendments Act

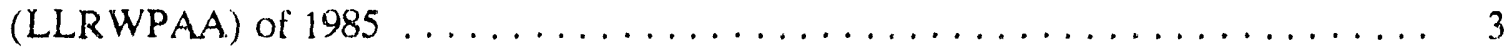

3. REGULATORY REQUIREMENTS FOR MIXED WASTE $\ldots \ldots \ldots \ldots \ldots \ldots \ldots$

3.1 Department of Energy (DOE) Orders $\ldots \ldots \ldots \ldots \ldots \ldots \ldots \ldots \ldots \ldots$

3.1.1 DOE 5820.2A Radioactive Waste Management .............. 4

3.1.2 DOE 5400.3 Hazardous and Radioactive Mixed Waste Program . . . . . . . 4

3.1.3 DOE 5400.1 General Environmental Protection Program ............ 4

3.2 The Atomic Energy Act (AEA) of $1954 \ldots \ldots \ldots \ldots \ldots \ldots \ldots \ldots \ldots$

3.3 Th. Solid Waste Disposal Act (SWDA) of $1965 \ldots \ldots \ldots \ldots \ldots \ldots$

3.4 The Resource Conservation and Recovery Act (RCRA) of $1976 \ldots \ldots \ldots \ldots \ldots$. . . 4

3.5 The Toxic Substance Control Act (TSCA) of $1976 \ldots \ldots \ldots \ldots \ldots$

3.5.1 TSCA: PCB's Manufacturing, Processing, Distribution in Commerce, and Use

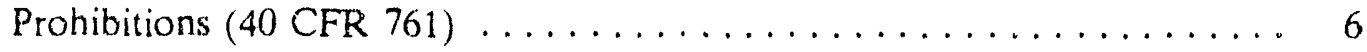

3.6 The Hazardous and Solid Waste Amendments (HSWA) to RCRA (1984) . . . . . 6 
3.6.1 Land Disposal Restrictions (LDRs) $\ldots \ldots \ldots \ldots \ldots \ldots \ldots \ldots \ldots \ldots \ldots$

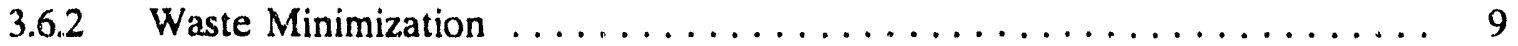

3.7 The Low-Level Radioactive Waste Policy Amendments Act

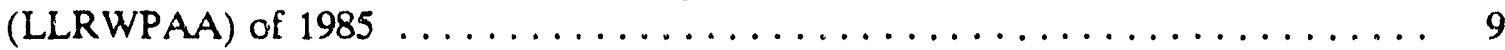

4. REASONS FOR TREATMENT OF LOW-LEVEL, WASTE $\ldots \ldots \ldots \ldots \ldots \ldots \ldots \ldots$

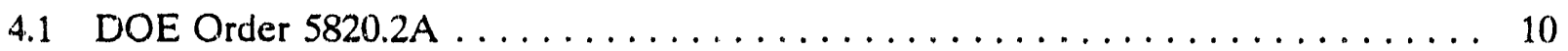

4.1 .1 Performance Objectives $\ldots \ldots \ldots \ldots \ldots \ldots \ldots \ldots \ldots \ldots \ldots$

4.1.2 Cost Effectiveness $\ldots \ldots \ldots \ldots \ldots \ldots \ldots \ldots \ldots \ldots \ldots \ldots \ldots \ldots$

4.2 The "Right Thing To Do" $\ldots \ldots \ldots \ldots \ldots \ldots \ldots \ldots \ldots \ldots \ldots \ldots \ldots \ldots$

4.3 Public Perception of DOE $\ldots \ldots \ldots \ldots \ldots \ldots \ldots \ldots \ldots \ldots \ldots \ldots \ldots \ldots \ldots$

4.4 Utilization of Advanced Disposal Techniques $\ldots \ldots \ldots \ldots \ldots \ldots \ldots \ldots \ldots \ldots$

5. REASONS FOR TREATMENT OF MIXED WASTE $\ldots \ldots \ldots \ldots \ldots \ldots \ldots \ldots \ldots$

5.1 EPA Regulations $\ldots \ldots \ldots \ldots \ldots \ldots \ldots \ldots \ldots \ldots \ldots \ldots \ldots \ldots$

6. CONCLUSIONS $\ldots \ldots \ldots \ldots \ldots \ldots \ldots \ldots \ldots \ldots \ldots \ldots \ldots \ldots \ldots$

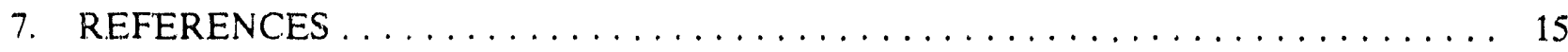

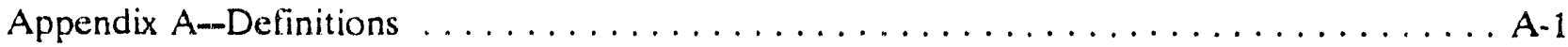




\section{ACRONYMS}

AEA

BDAT

BRC

CAA

CFR

DOE

DOE-ID

EPA

FR

FY

HSWA

HWMA

INEL

LDR

LLRWPAA

LLW

MLLWTF

NRC

OSHA

PCB

RCRA

SWDA
Atomic Energy Act

Best Demonstrated Available Technology

Below Regulatory Concern

Clean Air Act

Code of Federal Regulations

Department of Energy

Department of Energy Idaho Field Office

Environmental Protection Agency

Federal Register

Fiscal Year

Hazardous and Solid Waste Amendments

Hazardous Waste Management Act

Idaho National Engineering Laboratory

Land Disposal Restrictions

Low-Level Radioactive Waste Policy Amendments Act

Low-Level Waste

Mixed and Low-Level Waste Treatment Facility

Nuclear Regulatory Commission

Occupational Safety and Health Act

Polychlorinated biphenyls

Resource Conservation and Recovery Act

Solid Waste Disposal Act 
Site Specific Plan

TOC

- Total Organic Carbon

TSD

Treatment, Storage, and Disposal

TSCA

Toxic Substance Control Act

WERF

Waste Experimental Reduction Facility

WM

Waste Management 


\section{Regulatory Justification for the Treatment of Mixed and Low-Level Waste at the Idaho National Engineering Laboratory}

\section{AUTHORITY}

\subsection{Low-Level Waste}

The Atomic Energy Act (AEA) provides authority to govern the possession and use of special nuclear materials, source material, and by-product material. Department of Energy (DOE) is primarily responsible for exercising this authority over Government-owned and -operated facilities. DOE is exempt from Nuclear Regulatory Commission (NRC) regulations except as specified in Section 202 of the Energy Reorganization Act of 1974 (i.e., DOE facilities that accept commercial high-level waste are licensed by the NRC). DOE develops orders to carry out the authority granted by the AEA. DOE orders are legally enforceable against Management and Operation contractors that operate DOE installations.

\subsection{Mixed Waste}

A dual regulatory framework exists for mixed waste, with EPA or authorized states regulating the hazardous waste component and NRC, NRC agreement states, or DOE regulating the radioactive waste component.

In passing RCRA Sections 3006(b) and (f), Congress expected that eventually all aspects of hazardous waste management would be transferred voluntarily from EPA to authorized states. The EPA's authorization requirements are given in 40 CFR 271. Authorization is granted through a joint regional and headquarters review and approval process for specific components of the state's program. The Idaho Hazardous Waste Management Act (HWMA), passed by the State of Idaho, provides the state with authority to implement the provisions of RCRA. In addition to the basic RCRA program, Idaho has also received authorization to administer the mixed waste portion of the program. Once authorized, the state has primary responsibility for implemeritation and enforcement of RCRA requirements within its boundaries. However, EPA, retains oversight and enforcement authority. 


\section{REGULATORY REQUIREMENTS FOR LOW-LEVEL WASTE}

\subsection{Department of Energy (DOE) Orders}

The DOE provides rules in the DOE Manual (10 CFR Parts 900 and following) for use in its facilities owned and operated either directly by the department or by any of its contractors. DOE has established an extensive system of standards and requirements through its orders to ensure safe operation of its facilities. Compliance with these orders is mandatory for contractors operating DOEowned facilities.

\subsubsection{DOE 5820.2A Radioactive Waste Management}

This order establishes policies, guidelines, and minimum requirements by which DOE manages its radioactive and mixed waste contaminated facilities. It also says that treatment of radioactive wastes, and other pollutants or hazardous substances they contain, will comply with all applicable federal, state, and local environmental, safety, and health laws and regulations and DOE requirements.

Chapter III, Management of Low-Level Waste, says "DOE-low-level waste shall be managed on a systematic basis using the most appropriate combination of waste generation reduction, segregation, treatment, and disposal practices so that the radioactive components are contained and the overall system cost effectiveness is maximized." Appropriate treatment methods are required to increase the life of disposal facilities and to insure the disposal site can meet the performance objectives stated in this chapter. The use of treatment techniques to improve facility performance, by improved site stability and reduction of infiltrating water, is required to the extent it is cost effective. And the use of treatment techniques to reduce volume and provide more stable waste forms shall be implemented as necessary to meet performance requirements.

\subsubsection{DOE 5400.1 General Environmental Protection Program}

This order establishes compliance with applicable environmental statutes, regulations, and standards to protect the environment and public for the conduct of DOE operations. It requires programs to comply with mandatory external requirements unless exempt.

\subsection{The Atomic Energy Act (AEA) of 1954, as Amended (42 USC 2011 et seq.)}

This law established the Atomic Energy Commission (now NRC) as the Federal agency having responsibility for the regulation of source, special nuclear, and by-product material. The AEA authorizes DOE to establish standards to protect health or minimize dangers to life or property.

\subsubsection{Environmental Protection Agency (EPA)}

EPA has responsibility under the AEA for setting radiation protection standards, which must be implemented by other Federal agencies. One such standard is for the management and land disposal of LLW. EPA will use this authority to propose generally applicable environmental 
standards for land disposal of LLW under 40 CFR 193. Other standards may include limits on radiation exposure to workers and members of the general public, and concentrations or quantities of radioactive materials in an uncontrolled area. The agency's task is therefore to evaluate the data on the behavior of radioactive materials in the environment and the biological effects of exposure to radiation and identify levels that achieve a desired level of protection.

\subsection{The Low-Level Radioactive Waste Policy Amendments Act (LLRWPAA) of 1985}

These amendments established deadlines for states and compacts to develop new disposal capacity for low-level radioactive waste. However, low-level waste produced by "atomic energy defense activities" and "federal research and development activities" is not subject to the provisions of the LLRWPAA requiring states to provide disposal capability. These particular wastes are disposed of at government facilities. 


\section{REGULATORY REQUIREMENTS FOR MIXED WASTE}

\subsection{Department of Energy (DOE) Orders}

\subsubsection{DOE 5820.2A Radioactive Waste Management}

See Section 2.1 .

\subsubsection{DOE 5400.3 Hazardous and Radioactive Mixed Waste Program}

This order establishes hazardous and radioactive mixed waste policies and requirements that implement RCRA within the framework of the environmental programs established under DOE 5400.1.

DOE's policy is to manage radioactive mixed waste according to the requirements of Subtitle $C$ of RCRA, and the AEA, respectively. RCRA applies to the extent that it is not inconsistent with the AEA. The radioactive component of the waste is subject to the requirements of DOE 5820.2A. It is also policy to implement a mixed waste program that complies with all applicable laws and regulations, and utilizes waste minimization techniques as specified in RCRA.

\subsubsection{DOE 5400.1 General Environmental Protection Program}

See Section 3.1.

\subsection{The Atomic Energy Act (AEA) of 1954}

See Section 2.2 .

\subsection{The Solid Waste Disposal Act (SWDA) of 1965}

This was the first Federal solid waste statute. It was enacted for the primary purpose of improving solid waste disposal methods.

\subsection{The Resource Conservation and Recovery Act (RCRA) of 1976}

This amendment to the SWDA was enacted as a framework for the management of both hazardous and non-hazardous waste. Under RCRA, EPA is responsible for identifying wastes that are subject to regulation and for regulating and permitting generators, transporters, treaters, storers, and disposers of waste covered by the regulations. It also granted EPA broad authority to promulgate regulations as necessary to protect human health and the environment from adverse impacts associated with hazardous waste management.

A notice issued July 3, 1986 (51 FR 24504) states that the EPA and its authorized states will regulate the hazardous component of a mixed waste management stream through its RCRA program. This notice was issued to clarify EPA's interpretation of RCRA Section 1004(27), which excludes 
"source, special nuclear, and byproduct material" from regulation under RCRA. EPA interpreted this exclusion to be specific only to the radioactive component of mixed waste.

RCRA Section 1006 establishes that RCRA applies to the following acts, unless it is found to be inconsistent with them:

- The Federal Water Pollution Control Act

- The Safe Drinking Water Act

- The Marine Protection, Research, and Sanctuaries Act

- The Atomic Energy Act

This section also states that RCRA provisions are to be integrated, to the maximum extent possible for administration and enforcement, into:

- The Clean Air Act

- The Federal Water Pollution Control Act

- The Federal Insecticide, Fungicide, and Rodenticide Act

- The Safe Drinking Water Act

- The Marine Protection, Research, and Sanctuaries Act

- The Surface Mining Control and Reclamation Act

It is important to note that Congress only required "integration" of those programs with RCRA that were under the direct control of EPA. The AEA is implemented primarily by DOE and NRC and is therefore excluded from the list requiring integration.

Section 1006 of RCRA additionally states that: "Nothing in this Act shall be construed to apply to (or to authorize) any state, interstate, or local authority to regulate any activity or substance which is subject to the Atomic Energy Act of 1954 (42 U.S.C. 2011 et seq.) except to the extent that such application (or regulation) is not inconsistent with the requirements of such [Act]."

\subsection{The Toxic Substance Control Act (TSCA) of 1976}

This act provides EPA with authority to require testing of chemical substances, both old and new, entering the environment and to regulate them where necessary. This authority supplements sections of existing toxic substance laws, such as the Clean Air Act (CAA), Federal Water Pollution Control Act, and the Occupational Safety and Health Act (OSHA). 


\subsubsection{TSCA: PCB's Manufacturing, Processing, Distribution in Commerce, and Use Prohibitions (40 CFR 761)}

This regulation is applicable to all treatment, storage, and disposal facilities dealing with polychlorinated biphenyls (PCB's). It establishes the requirements for the disposal and storage of PCB's and PCB items. PCB's in excess of $50 \mathrm{ppm}$ are fully regulated.

\subsection{The Hazardous and Solid Waste Amendments (HSWA) to RCRA (1984)}

These amendments to RCRA established minimum technology requirements for land disposal facilities and surface impoundments, corrective action requirements for hazardous waste facilities seeking permits under RCRA, statutory deadlines for promulgation of land disposal restrictions and treatment standards, small-quantity generator requirements, and waste minimization requirements. The passage of the Hazardous and Solid Waste Amendments (HSWA) shifted the focus away from land disposal of waste to a more comprehensive management system including waste reduction, recycling, and treatment.

\subsubsection{Land Disposal Restrictions (LDRs)}

The 1984 Hazardous and Solid Waste Amendments (HSWA) to RCRA, through the land disposal restrictions (LDR), prohibit disposal of hazardous and mixed wastes that have not been treated to standards required by EPA, "unless the Administrator [EPA] determines that the prohibition...is not required in order to protect human health and the environment for as long as the waste remains hazardous..." (RCRA Section 3004(d)(1), (e)(1), and $(\mathrm{g})(5))$. This phrase is defined as meaning that there will be "no migration of hazardous constituents from the disposal unit...for as long as the waste remains hazardous." The HSWA amendments also prohibit any storage of a land disposal restricted waste unless the storage is for the sole purpose of accumulating sufficient quantities in a tank or container to facilitate proper recovery, treatment, or disposal of that waste (40 CFR 268.50).

Waste treated in accordance with treatment standards set by EPA under Section $3004(\mathrm{~m})$ of RCRA are not subject to the prohibitions and may be land disposed. The statute requires EPA to set "levels or methods of treatment, if any, which substantially diminish the toxicity of the waste or substantially reduce the likelihood of migration of the hazardous constituents from the waste so that short-term and long-term threats to human health and the environment are minimized." (RCRA Section $3004(\mathrm{~m})(\mathrm{l})$.)

All mixed waste was subject to the RCRA land disposal restrictions by May 8, 1990 unless:

- It was generated prior to the effective date of the LDRs and has not been removed from the storage or disposal unit where it was placed (residues generated from such wastes, like leachate or contaminated groundwater, are subject to regulation); 
- Is in a state that is authorized for RCRA's base program but has not yet received authorization for mixed waste; or

- Is a newly identified or listed waste after November 8, 1984 for which treatment standards have not been promulgated.

HSWA directed EPA to establish treatment standards for each of the seven groups of RCRA hazardous wastes by specific dates. These dates, referred to as statutory deadlines, are given below, and will eventually restrict land disposal of all RCRA hazardous waste.

The first group of wastes subject to the LDR regulations were mixed radioactive and RCRA hazardous wastes that contain spent solvents, dioxins, and the California List wastes. The remaining RCRA hazardous wastes were placed in three groups known as the first-, second-, and third-thirds. EPA deferred issuing treatment standards for radioactive wastes mixed with first-third and secondthird hazardous wastes until the statutory effective date for the third-third, May 8, 1990.

According to EPA's June 1, 1990 final rule on the third-third waste, mixed wastes containing hazardous wastes identified on the first-, second-, or third-third lists will not be subject to the federal land disposal restrictions until May 8,1992, because EPA issued a two-year national capacity variance for all mixed waste that is not a solvent, dioxin, or California List waste (55 FR 22520). This variance can be granted under the authority of HSWA Section 201, if EPA makes the determination that insufficient treatment capacity exists nationwide, and may be extended for a maximum of two more years on a case-by case basis. When the variance expires on May 8, 1992, unless an extension is granted, all mixed wastes will be prohibited from land disposal without pretreatment to EPA standards, and from storage except to accumulate sufficient quantities to facilitate proper recovery,

\begin{tabular}{ll}
\multicolumn{1}{c}{ Waste } & Statutory deadline \\
\hline $\begin{array}{l}\text { Spend solvent and dioxin } \\
\text { containing wastes } \\
\text { California list wastes }\end{array}$ & November 8,1986 \\
First-third wastes & July 8, 1987 \\
Spent solvent, dioxin- & August 8, 1988 \\
containing and CA list soil & November 81988 \\
and debris from CERCLA/ & \\
RCRA corrective actions & \\
Second-third wastes & June 8, 1989 \\
Third-third wastes & May 8, 1990 \\
Newly identified wastes & Within 6 months \\
& of identification \\
& as a hazardous \\
& waste \\
\hline
\end{tabular}


treatment, or disposal. The storage prohibition does not affect those scheduled third mixed wastes that are disposed or stored prior to May 8, 1992. Instead, the prohibition addresses storage of scheduled third mixed wastes first placed into storage after May 8, 1992 unless the wastes are granted an additional variance.

EPA has established treatment standards under the LDRs on the basis of the best demonstrated available technology (BDAT). EPA only considers treatment technologies that have been demonstrated by full-scale operation. To be a BDAT the technology must also be commercially available, present less risk to human health and the environment than land disposal of untreated waste, and provide substantial treatment. Within this framework the agency has established three types of LDR treatment standards:

- Concentration levels-which must be attained before the wastes or treatment residuals may be land disposed;

- Specified technologies-which must be applied to the wastes before the treatment residuals may be land disposed; and

- No land disposal-which prohibits land disposal of certain restricted hazardous wastes.

The majority of the LDR treatment standards promulgated to date are concentration levels. For wastes with treatment standards expressed as concentrations, any technology that can achieve the required levels may be used unless that technology is otherwise prohibited. EPA has promulgated separate standards for wastewaters and non-wastewaters for treatment standards expressed as concentration levels. For LDRs, wastewaters normally are defined as wastes containing less than one percent total organic carbon (TOC) and less than one percent total suspended solids.

Once a BDAT has been identified for a particular waste, EPA next establishes an effective date for the land disposal restrictions based on the availability of that BDAT capacity. The land disposal restriction cule states that the RCRA-regulated hazardous portion of all mixed waste must meet the appropriate treatment standards for all applicable waste codes before land disposal. As soon as EPA sets a treatment standard, wastes subject to that standard are automatically prohibited from land disposal, unless the wastes meet the treatment standard or are disposed in an EPA approved no-migration unit $(3004(h)(1))$. To date, EPA has set special treatment standards for three categories of mixed low-level waste. They include: (1) radioactive lead solids; (2) radioactive elemental mercury; and (3) radioactive hydraulic oil contaminated with mercury. The remaining mixed wastes are subject to those promulgated treatment standards that apply to the hazardous portion of the waste unless EPA publishes specific standards for mixed waste treatability groups in the future (55 FR 22532 and 22626).

As a consequence of these amendments, generators of hazardous waste are responsible for ensuring adequate treatment of manifested wastes before shipment to a land disposal facility. Owner/operators of land disposal facilities may not accept wastes that exceed the land disposal restrictions unless they have on-site capabilities for treating the wastes to meet required standards or the wastes have been exempted under 40 CFR 268.5, 268.6, or 268.44. 


\subsubsection{Waste Minimization}

HSWA mandates that waste minimization be an integral part of the operations of facilities generating and handling hazardous waste, including mixed waste. Waste minimization, part of the overall pollution prevention program, specifically addresses the reduction of hazardous wastes.

Owners and operators of hazardous waste treatment, storage, or disposal facilities must certify that there is a waste minimization program in place and that the treatment, storage, or disposal (TSD) method proposed minimizes the present and future threat to human health and the environment.

\subsection{The Low-Level Radioactive Waste Policy An dments Act (LLRWPAA) of 1985}

See Section 2.3 . 


\section{REASONS FOR TREATMENT OF LOW-LEVEL WASTE}

Low-level waste is generally subjested to treatment to reduce the volume of waste requiring disposal, to change the waste form, and to separate the radioactive components from the nonradioactive component in the waste stream. Low-level waste treatment takes place when it is necessary to satisfy regulatory requirements or if it improves the overall cost effectiveness of disposal. Treatment involves processing of the wastes to produce a waste stream that has a smaller volume and higher concentration of radioactivity than the original, and a second stream of sufficiently lower radionuclide concentrations than the original waste to permit release or reuse.

Approximately $67 \%$ of the low-level waste disposed of on-site, is first processed before disposal by incineration, compaction or sizing to reduce volume and stabilize the waste to the extent possible. The "Maximurn Waste To WERF" carnfraign has been initiated by DOE to increase the percentage of waste processed prior to disposal.

Pre-treatment, transportation, and political issues hinder regionalization prospects. Therefore, no effort exists to coordinate national low-level waste treatment utilizing common facilities, forcing DOE sites to develop redundant capabilities.

There are a variety of treatment technologies that may be used to dispose of low-level waste in compliance with federal regulations and DOE orders. The choice among these technologies entails a balancing of factors and reflects the relative importance of such considerations as relative exposure of members of the public, relative occupational exposure, relative ease of post-closure care and/or monitoring, compatibility with site-specific environmental parameters, public perception, and cost.

\subsection{DOE Order 5820.2A}

\subsubsection{Performance Objectives}

Performance obje 'ives take the form of limiting dose constraints to the public and on-site workers. The performance objectives listed in DOE Order 5820.2A are to:

1. Protect public health and safety in accordance with standards specified in applicable EH Orders and other DOE orders.

2. Assure that enternal sposure to the waste and concentrations of radioactive material which may be released into surface water, groun' water, soil, plants and animals results in an effective dose equivalent that does nor exceed $25 \mathrm{mrem} / \mathrm{yr}$ to any member of the public. Releases to the atmosphere slsall meet the requirements of 40 CFR 61 . Reasonable effort should be made to maintain releases of radioactivity in effluents to the general environment as low is reasonably achievable.

3. Assure that the committed effective dose equivalents received by individuals who inadvertently may intrude into the facility after the loss of active institutional control ( 100

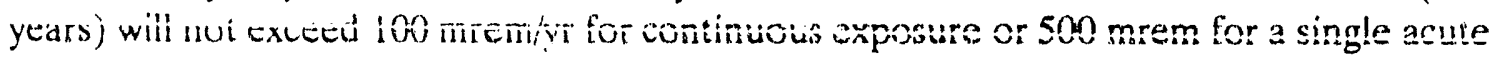
exposure. 
4. Protect ground water resources, consistent with Federal, State and local requirements.

\subsubsection{Cost Effectiveness}

With the increasing pressures to reduce the volume of low-level waste for disposal, the ability to minimize waste generation and optimize subsequent processing to achieve a high degree of costeffectiveness, volume reduction becomes a significant aspect of low-level waste management. In commercial industry, volume reduction pressures derive primarily from the increasing costs of transportation and disposal of low-level wastes. Since there is no cost to generators for disposal of wastes at the INEL, volume reduction is driven by the need to maximize the longevity of currently available disposal sites at the INEL.

\subsection{The "Right Thing To Do"}

Treatment of wastes is a very important part of DOE-ID's waste management mission. As stated in the Environmental Restoration and Waste Management Site-Specific Plan (SSP) for Fiscal Year 1992 (FY-92) (DOE/ID-10253) part of the mission of the INEL is development, transfer, and deployment of technologies to avoid and/or dispose of hazardous and/or radioactive waste and for remediation/restoration of previous disposal sites to protect the public, employees, and environment. Treatment of waste to reduce volume and increase stability, is one of the activities identified by the SSP for FY.92 to be incorporated into all aspects of waste management. This plan also states that "DOE-ID will make every effort to prevent waste of any type from accumulating at treatment or storage facilities without treatment and disposal options clearly identified."

To support the goal for cleanup of its sites by 2019 and to reduce program costs, DOE has established an aggressive applied research, development, testing, and evaluation program. One of the tasks the Technology Development Program is working on is the development of new treatment technologies to minimize the toxicity and volume of waste generated by DOE-ID.

In the future, the focus of operations at the INEL will be on waste avoidance. Specific objectives to substantially reduce and/or eliminate wastes of all types is not feasible based on current INEL treatment capabilities. To meet the long-term vision of the INEL, waste generation will need to be reduced to the minimum amount possible, and all wastes will need to be treated to meet applicable requirements. In support of this, one of the goals of the INEL low-level waste program is new mixed/low-level treatment and disposal operations.

\subsection{Public Perception of DOE}

Increased social awareness of waste management issues has caused these issues to receive more attention than had been the rase in the past. To some extent this has been the result of increased concern over DOE's capability of disposing of waste on-site. The INEL has a responsibility to the public: as a leader in research and development of waste treatment technologies, to provide the capacity for treatment of DOE generated waste and alleviate on-site disposal problems.

Low-level radioactive waste produced at the INEL is disposed on-site. This practice provides benefits in terms of continuing government controi over the sile and nateital and providing the most 
cost effective means of managing the waste. Shallow land burial is the disposal method of choice because it is an extension of conventional practice with other waste materials, it provides shielding for those waste materials with substantive external radiation levels, soil properties would generally retard the migration of contained radicnuclides, and the need for transportation is reduced. To increase the life of the INEL's low-level waste disposal sites, the waste must be treated, prior to burial, to reduce its volume.

The siting and operation of new radioactive waste treatment, storage, and disposal facilities are governed by the need to ensure short- and long-term protection of public health and the environment. This protection is required by the provisions incorporated in federal laws and regulations, and DOE orders which govern radioactive waste management operations. The treatment of low-level waste, prior to burial, would result in more stable waste forms with reduced volumes, increasing the likelihood of conformance to the long-term protection requirement.

\subsection{Utilization of Advanced Disposal Techniques}

The technology currently in use for the disposal of low-level waste at DOE facilities is shallow land burial in trenches, pits, or other near surface disposal units. However, as a result of past inadequacies associated with shallow land burial and concern about long-term containment capability, the use of advanced disposal techniques should be considered. Even though federal governmental and private authorities consider shallow land burial adequate to contain low-level waste over the long term with no degradation to the environment, public and local governmental pressures may mandate the use of advanced disposal alternatives.

At this time, advanced disposal techniques are not feasible for the quantities of low-level waste generated at the INEL. Treatment of this waste for reduction of volume, would give the INEL the capability of utilizing some cf the advanced disposal techniques currently available. These disposal methods, for example concrete vaults, liners, or bunkers, offer much greater short- and long. term protection factors to public health and the environment, making them a more desirable disposal option. Additionally, they also provide barriers to contaminant dispersion, and potentially permit future retrieval of the waste. These options would only be feasible if the volume of low-level waste for disposal is reduced, and treatment is one way to accomplish that. Implementing new disposal techniques will serve to enhance the INEL's image for waste management by significantly reducing the chance of contaminating the environment. 


\section{REASONS FOR TREATMENT OF MIXED WASTE}

The priority rationale for the treatment of mixed waste is avoidance of impacts (including fines) for the violation of EPA/State regulations and agreements. There are social and economic reasons for the treatment of mixed waste, but the fact that it will be illegal not to treat this waste outweighs any other considerations. The reasons for treatment of low-level waste (Section 4.) also apply to the treatment of mixed waste.

\subsection{EPA Regulations}

DOE regulations permit land disposal restricted wastes to be stored until radionuclides decay to a level at which they can be disposed of by approved methods. However RCRA rules mandate one very important additional restriction: indefinite storage of LDR wastes is prohibited, and a capability to treat such wastes must be installed. Current mixed waste treatment capability and capacity at the INEL is not adequate to meet RCRA requirements. Without treatment and disposal alternatives for mixed waste, the ability to meet land disposal restrictions and storage limitations established by RCRA is a major concern. At this time, California List and solvent containing mixed wastes are being stored out of compliance with storage prohibitions for hazardous waste under 40 CFR 268. When the National Capacity Variance expires on May 8, 1992, unless an extension is granted on a case-by-case basis, all third-third mixed wastes will be prohibited from storage except to accumulate sufficient quantities to facilitate proper recovery, treatment, or disposal. Without treatment capabilities in place to process mixed waste, the storage of this waste for any period of time, will violate EPA regulations. As published in the August 29, 1991 Federal Register, FR 3991-3, "Policy on Enforcement of RCRA Section 3004(j) Storage Prohibition at Facilities Generating Mixed Radioactive/Hazardous Wastes," the EPA considers violations of this section to fit within the agency's civil enforcement priorities.

In addition to the storage prohibition, the disposal of third-third mixed wastes that have not been treated to the standards required by EPA will also be prohibited when the variance expires. The key to satisfying LDR requirements is the implementation of appropriate treatment capabilities for these mixed waste streams. A mixed waste treatment facility would allow these wastes to be processed in accordance with EPA standards under Section 3004.(m) of RCRA. The end result of the treatment process is that the waste is no longer subject to these prohibitions and may be land disposed at an appropriate disposal facility.

Generators of mixed waste, under 40 CFR 268, are responsible for ensuring adequate treatment of manifested wastes before shipment to a land disposal facility. In order for generators to meet this requirement, treatment capabilities and capacities need to be developed for the INEL. 


\section{CONCLUSIONS}

Support for the proposed design and construction of a mixed and low-level waste treatment facility is a result of the need for treatment of projected inventories of mixed and low-level waste streams at the INEL. In the case of low-level waste, treatment is used to maximize the longevity of existing and proposed disposal sites, as well as creating a more stable waste form. With the increasing pressures to reduce the volume of mixed and low-level waste for disposal, the ability to achieve a high degree of cost-effective volume reduction becomes a significant aspect of waste management. In the case of mixed waste, treatment will allow compliance with EPA regulations for the protection of human health and the environment. Without treatment and disposal alternatives for mixed waste, the ability to meet the land disposal restrictions and storage limitations established by RCRA is a major concern.

There are a variety of treatment technologies that may be used to allow disposal of mixed and low-level waste in compliance with federal regulations and DOE orders. The choice among these technologies entails a balancing of factors and reflects the relative importance of such considerations as exposure, ease of post-closure care and/or monitoring, compatibility with site-specific environmental parameters, availability, public perception, and cost.

Analysis of EPA and DOE requirements for managing mixed and low-level wastes make it clear that current mixed and low-level waste treatment capability and capacity at the INEL is not adequate to meet these requirements. Hazardous waste treatment technologies were developed for typical industrial wastes, which were the type evaluated by EPA in developing treatrnent standards. Most DOE wastes fall into very different categories. Consequently, current EPA designated treatments may be inapplicable to DOE wastes. There is a need to identify treatments that will destroy or fix DOE mixed wastes to meet EPA standards. Although identifying treatment technologies is important, it is not enough to avoid noncompliance with EPA regulations. These treatment technologies must be installed and implemented with sufficient capacity to handle projected volumes of mixed waste generated at the INEL.

In the future, the focus of operations at the INEL will be on waste avoidance. Specific objectives to substantially reduce and/or eliminate wastes of all types is not feasible based current INEL treatment capabilities. To meet the long-term vision of the INEL, waste generation will need to be reduced to the minimum amount possible, and all wastes will need to be treated to meet applicable requirements. In support of this, one of the goals of the INEL needs to be the development of a mixed and low-level waste treatment facility. 


\section{REFERENCES}

1. R. E. Berlin and C. C. Stanton, Radioactive Waste Management, New York, John Wiley \& Sons, 1989.

2. Cooje of Federal Regulations, 40 CFR 268, "Land Disposal Restrictions."

3. Code of Federal Regulations, 40 CFR 261, "Identification and Listing of Hazardous Waste."

4. DOE/ID-10253, Environmental Restoration and Waste Management Site-Specific Plan (SSP) for Fiscal Year 1992 (FY-92), September 1991.

5. U.S. DOE, "Radioactive Waste Management," DOE 5820.2A, September 26, 1988.

6. U.S. DOE, "Hazardous and Radioactive Mixed Waste Program," DOE 5400.3, February 22, 1989.

7. U.S. DOE, "General Environmental Protection Program," DOE 5400.1. November 9, 1988.

8. Code of Federal Regulations, 10 CFR 61, "Licensing Requirements for the Land Disposal of Radioactive Waste."

9. Code of Federal Regulations, 40 CFR 271, "Requirements for Authorization of State Hazardous Waste Programs."

10. Code of Federal Regulations, 40 CFR 761, "PCB's Manufacturing, Processing, Distribution in Commerce, and Use Prohibitions."

11. FR 3991-3, "Policy on Enforcement of RCRA Section 3004(j) Storage Prohibition at Facilities Generating Radioactive/Hazardous Wastes," U.S. Environmental Protection Agency, August 29, 1991.

12. L. Chang, T. D. Kirkpatrick, and D. C. Fabib, "LDR Assessment of DOE Mixed Waste," Mixed Waste, Proceedings of the First Internatiomal Symposium, Baltimore, Maryland, August 26-29, 1991.

13. L. W. Smith and J. Talarico, "DOE Mixed Waste Treatment and Disposal Facilities," Mixed Waste, Proceedings of the First International Symposiul t, Baltimore, Maryland, August 26-29, 1991. 
APPENDIX A

\section{DEFINITIONS}

A-1 


\section{DEFINITIONS}

\section{Hazardous Waste}

As defined in 40 CFR 261.3, hazardous waste is a solid waste that is not excluded from regulation under 40 CFR 261.4, and either exhibits a characteristic of hazardous waste identified in 40 CFR 261 Subpart C, or is listed in 40 CFR 261 Subpart D.

\section{Low-Level Waste}

The Low-Level Radioactive Waste Policy Amendments Act (LLRWPAA) of 1985 has defined low-level waste as that waste containing source, special nuclear, or byproduct material that is not classified as high-level radioactive waste, transuranic waste, spent nuclear fuel, or byproduct material as defined in Section 11e.(2) of the Atomic Energy Act (AEA). Test specimens of fissionable material irradiated for research and development only, and not for the production of power or plutoniurn, may be classified as low-level waste, provided the concentration of transuranic is less than $100 \mathrm{nCi} / \mathrm{g}$. (U.S. DOE, Radioactive Waste Management, DOE 5820.2A, September 26, 1988)

Classification of Low-Level Radioactive Waste. Classification of low-level waste is described in $10 \mathrm{CFR} 61.55$ and involves consideration for the presence of both long-lived and short-lived radionuclides. Three classifications of waste are established in 10 CFR 61: Class A, B, and C.

Class A Waste. This waste represents the lowest potential hazard level because of a combination of limited concentration and short half-life characteristics. External radiation levels for packages containing Class A waste are generally low enough to allow direct handling. Protection of operating personnel and the public during operation is the main objective with Class $\mathrm{A}$ waste. The physical form of the waste must meet the minimum requirements set forth in 10 CFR 61.56(a).

Class B Waste. This waste contains higher concentrations of radioactivity. Class B waste is generally handled using shielded casks or remote handling. The waste form requirements are more stringent for Class $B$ waste because the higher concentration and longer hazardous life mean that protection must be continued beyond the operating lifetime of the facility. The physical form and characteristics of Class B waste must meet both the minimum and stability requirements set forth in $10 \mathrm{CFR} 61.56$.

Class C Waste. This waste is the limit for near-surface disposal because of the concentrations involved and/or the length of time the material will persist. Class $C$ waste is usually heavily shielded during handling and barriers are required to reduce the probability and consequences of inadvertent intrusion into the waste through excavation, agriculture, or plant or animal uptake. The "inadvertent intruder" risk is evaluated at 500 year post-closure. The physical form and characteristics of Class $C$ waste must meet both the minimum and stability requirements set forth in 10 CFR 61.56 .

Reclassified Low-Level Wasie. Waste that was previously classified as transuranic waste, but has concentrations of transuranic radionuclides below the currently established limit of $100 \mathrm{nCi} / \mathrm{g}$ for 
transuranic waste. Reclassified low-level waste is generally above the $10 \mathrm{nCi} / \mathrm{g}$ of transuranic radionuclides per gram of waste that requires additional controls and special handling. [DOE-ID, Environmental Restoration and Waste Management Site-Specific Plan (SSP) for Fiscal Year 1992), DOE-ID-10253 (FY-92), September 1991].

\section{Mixed Waste}

Waste containing both radioactive and hazardous components as defined by the AEA and the Resource Conservation and Recovery Act (RCRA), respectively. (U.S. DOE, Radioactive Waste Management, DOE 5820.2A, September 26, 1988)

Below Regulatory Concern. Nuclear Regulatory Commission (NRC) and Environmental Protection Agency (EPA) joint guidance also addressed wastes that are below regulatory concern (BRC) for radioactive waste. The joint NRC/EPA guidance on mixed waste states that, even though a waste may be BRC, if it contains a RCRA hazardous waste listed in 40 CFR 261, Subpart D, it retains its legal status as a mixed waste although it may not require disposal at a LLW disposal facility.

DOE Clarification of the Definition of By-Product Material. For the purpose of determining the applicability of RCRA, "by-product material refers to the actual radionuclides dispersed or suspended in any radioactive waste substance (except special nuclear material) yielded in, or made radioactive by exposure to, the radiation incident to the process of producing or utilizing special nuclear material." This clarification applies only to 11e.(2) by-product material. According to this clarification, only the actual radionuclides, not the entire waste stream, are considered by-product material; and thus, RCRA has authority to regulate the hazardous portion of the waste stream. (May 1, 198752 FR 15937)

\section{Treatment}

Any method, technique, or process designed to change the physical or chemical character of waste to render it less hazardous, safer to transport, store, or dispose of, or reduced in volume. (U.S. DOE, Radioactive Waste Management, DOE 5820.2A, September 26, 1988) 


\section{Preliminary Siting Requirements for the Proposed Mixed and Low-Level Waste Treatment Facility at the Idaho National Engineering Laboratory}

Deba Kufen

Published March 1992

Idaho National Engineering Laboratory

EG\&G Idaho, Inc.

Idaho Falls, Idaho 83415 


\section{ABSTRACT}

A preliminary siting requirements investigation was completed for the proposed Mixed and LowLevel Waste Treatment Facility (MLLWTF) to be located at the Idaho National Engineering Laboratory (INEL). The purpose of this investigation was to identify applicable siting requirements for the new facility. The requirements were identified by researching regulations and other site investigations performed at the INEL. The investigation revealed that siting requirements for the MLLWTF are based on Environmental Protection Agency regulations and Department of Energy Order 6430.1A, "General Design Criteria." These requirements were then divided into mandatory and differentiating categories to be used in the final site selection decision-making process. 


\section{CONTENTS}

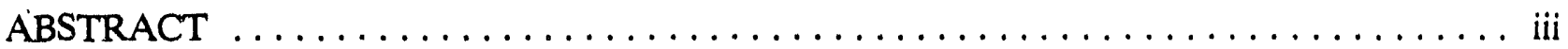

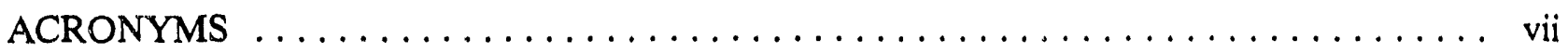

1. INTRODUCTION $\ldots \ldots \ldots \ldots \ldots \ldots \ldots \ldots \ldots \ldots \ldots \ldots \ldots \ldots \ldots \ldots \ldots \ldots$

2. ENVIRONMENTAL REGULATIONS $\ldots \ldots \ldots \ldots \ldots \ldots \ldots \ldots \ldots \ldots$

2.1 Standards for Owners and Operators of Hazardous Waste Treatment,

Storage, and Disposal Facilities, 40 CFR 264 Subpart B,

"General Facility Standards" ....................... 3

2.1.1 Seismic Considerations $\ldots \ldots \ldots \ldots \ldots \ldots \ldots \ldots \ldots \ldots$

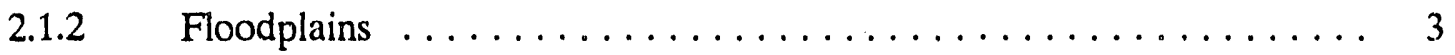

2.1.3 Salt Dome Formations, Salt Bed Formations, Underground

Mines, and Caves ..................... 4

2.2 Wild and Scenic Rivers Act (16 U.S.C. 1273 et seq.) $\ldots \ldots \ldots \ldots \ldots \ldots \ldots$

2.3 National Historic Preservation Act of 1966 (16 U.S.C. 470 et seq.) . . . . . . . 5

2.4 Endangered Species Act of 1973 (16 U.S.C. 1531 et seq.) $\ldots \ldots \ldots \ldots \ldots \ldots$

2.5 Fish and Wildlife Coordination Act (16 U.S.C. 661 et seq.) $\ldots \ldots \ldots \ldots \ldots$

2.6 Coastal Zone Management Act (16 U.S.C. 1451 et seq.) $\ldots \ldots \ldots \ldots \ldots \ldots$

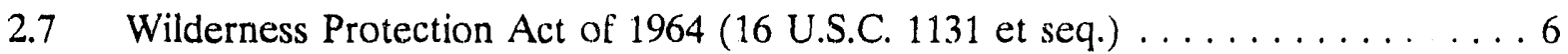

2.8 Toxic Substances Control Act of 1976 (15 U.S.C. 2601 et seq.) . . . . . . . . 6

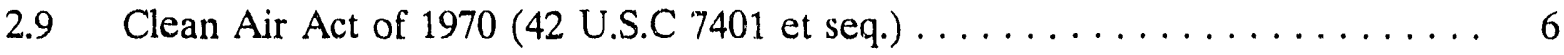

2.10 Wetlands (Executive Order 11990) $\ldots \ldots \ldots \ldots \ldots \ldots \ldots \ldots \ldots \ldots$

2.11 Floodplains (Executive Order 11988$) \ldots \ldots \ldots \ldots \ldots \ldots \ldots \ldots$

3. DOE Order 6430.1A, General Design Criteria $\ldots \ldots \ldots \ldots \ldots \ldots \ldots \ldots \ldots \ldots$

3.1 Section 0200, Site Development, Subpart 1, "Facility Siting" . . . . . . . . 8 
3.1.1 Radiological Siting Guidelines $\ldots \ldots \ldots \ldots \ldots \ldots \ldots$

3.2 Section 0285, Solid Waste Systems, Subpart 2, "Site Selection" . . . . . . . . . 9

3.2.1 Environmentally Sensitive Area $\ldots \ldots \ldots \ldots \ldots \ldots \ldots \ldots \ldots$

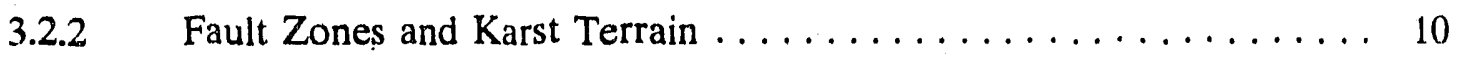

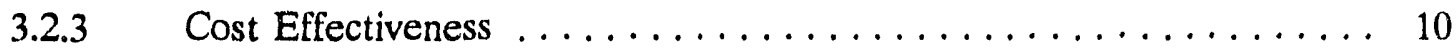

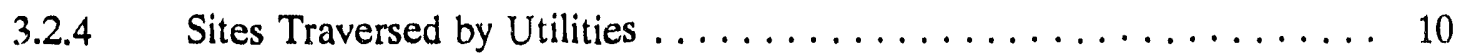

3.2.5 Characteristics and Availability of Soil Cover ............ 11

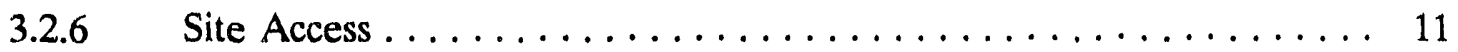

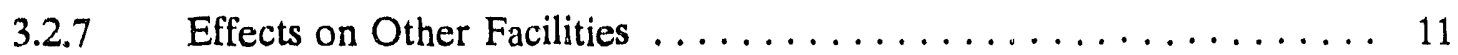

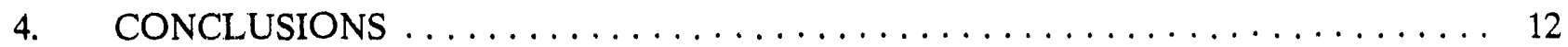

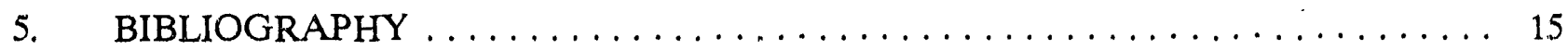

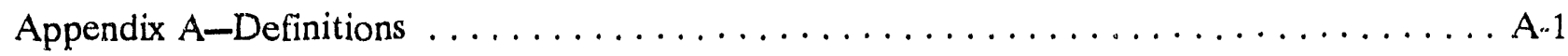

Appendix $\mathrm{B}-$ Geologic Timetable $\ldots \ldots \ldots \ldots \ldots \ldots \ldots \ldots \ldots \ldots \ldots \ldots \ldots \ldots$

Appendix C-Federal Threatened, Endangered, and Candidate Species

and State Species of Special Concern on the INEL $\ldots \ldots \ldots \ldots \ldots \ldots \ldots \ldots$ 


\section{ACRONYMS}

ACHP Advisory Council on Historic Preservation

AEA Atomic Energy Act

BLM Bureau of Land Management

CERCLA Comprehensive Environmental Response, Compensation, and Liability Act

CFR Code of Federal Regulations

DOE Department of Eiergy

DOT Department of Transportation

EPA Environmental Protection Agency

FR Federal Register

FWS Fish and Wildlife Service

GDC general design criteria

HSWA Hazardous and Solid Waste Amendments

ICRP International Commission on Radiological Protection

INEL Idaho National Engineering Laboratory

LCC life-cycle cost

MLLWTF Mixed and Low-Level Waste Treatment Facility

NRC Nuclear Regulatory Commission

PCB polychlorinated biphenyl

RCRA Resource Conservation and Recovery Act

SHPO State Historic Preservation Officer

TSCA Toxic Substances Control Act

TSD treatment, storage, and disposal 


\section{Preliminary Siting Requirements for the Proposed Mixed and Low-Level Waste Treatment Facility at the Idaho National Engineering Laboratory}

\section{INTRODUCTION}

The siting requirements for the proposed Mixed and Low-Level Waste Treatment Facility (MLLWTF) at the Idaho National Engineering Laboratory (INEL) are based on the Environmental Protection Agency (EPA) regulations rresented in Section 2, and Department of Energy (DOE) Order 6430.1A presented in Section 3. (NOTE: Definitions of terms in this report are provided in Appendix A).

The Atomic Energy Act (AEA) of 1954 (42 U.S.C 2011 et seq.) authorizes DOE to establish standards to protect health and minimize dangers to life and property. Through a series of DOE orders, DOE has established an extensive system of standards and requirements to ensure sate operations of its facilities. In accordance with the Energy Reorganization Act of 1974 [Public Law (PL) 93-438], only DOE facilities that accept commercial high-level waste are subject to licensing requirements by the U.S. Nuclear Regulatory Commission (NRC). Based on this requirement, siting of the MLLWTF is not subject to NRC regulations. 


\section{ENVIRONMENTAL REGULATIONS}

On December 18, 1978, the EPA proposed standards to control the location of treatment, storage, and disposal (TSD) facilities in seismic zones, 100-year floosiplains, coastal high hazard areas, 500-year floodplains, wetlands, critical habitats of endangered and threatened species, and recharge zones of sole-source aquifers, as well as specific standards to delimit the location of active prortions of facilities with respect to the facilities' property lines. Public comment and additional research regarding the proposed standards were evaluated, and on January 12,1981, the EPA promulgated two of the eight candidate standards, the 100-year floodp'ain and seismic zone restrictions, in their Resource Conservation and Recovery Act (RCRA) regulations. The 500-year floodplain restriction was rejected as unnecessary to protect human health and the environment, while the other five standards were not promulgated because they were at least partially addressed by other laws. These minimum location standards for hazardous waste TSD facilities are contained in 40 CFR 264.18, and are discussed in Section 2.1 of this report.

Considerations affecting siting are also found in 40 CFR 270.14 (b) and (c), "Contents of Part B: General Requirements." These requirements reflect the standard's promulgated in 40 CFR 264.18 and are necessary for the EPA to determine compliance with the Part 264 standards, and are also discussed in Section 2.1 with the Part 264 regulations.

The EPA requires that other Federal laws that affect the location and permitting of TSD facilities be considered ( 40 CFR 270.3). When any of these laws is applicable, its procedures must be followed. These Federal laws are contained in Sections 2.2 through 2.11 of this report.

Section 3004(0)(7) of RCRA, which was added by the Hazardous and Solid Waste Amendments (HSWA) of 1984, requires the EPA to publish guidance identifying areas of vulnerable hydrogeology. This guidance was completed and issued in July 1986, and will be used to help evaluate sites for the proposed MLLWTF. This section of RCRA also requires the EPA to specify criteria for the acceptable location of new and existing TSD facilities as necessary to protect human health and the environment. The 56 Federal Register (FR) 18024, issued April 22, 1991, contained the EPA's announcement of plans to develop additional location standards restricting the siting of hazardous waste facilities in environmentally sensitive areas. The EPA's goal for the location standards is to ensure that new TSD facilities are sited in the most suitable locations and are protective of human health and the environment. The final action on these standards is due in April of 1993. It is difficult to assess how these new standards will affect siting at the INEL, so this subject will have to be readdressed when the new standards are promulgated. 


\subsection{Standards for Owners and Operators of Hazardous Waste Treatment, Storage, and Disposal Facilities, 40 CFR 264 Subpart B, "General Facility Standards"}

Location standards for TSD facilities are regulated by the EPA under 40 CFR 264.18. These regulations address seismic considerations, floodplains, salt dome formations, salt bed formations, underground mines, and caves. The applicability of these regulations to the proposed MLLWTF are discussed in the following subsections.

\subsubsection{Seismic Considerations}

Portions of new facilities where treatment, storage, or disposal of hazardous waste will be conducted must not be located within 61 meters (200 feet) of a fault that has had displa:ement in Holocene time, i.e. during the last 10,000 years (See Appendix B). The intent of this standard is to ban new TSD facilities in locations on or near faults that are likely to experience displacement in the future.

In order to demonstrate the applicability of the seismic standard, the owner or operator of a new facility must identify the political jurisdiction in which the proposed facility is to be located (40 CFR 270.14). If the county is not listed in Appendix VI of Part 264, no further requirement is required to demonstrate compliance with 264.18. The Idaho counties listed in Appendix VI are Bannock, Bear Lake, Bingham, Bonneville, Caribou, Cassia, Clark, Franklin, Fremont, Jefferson, Madison, Oneida, Power, and Teton. The counties that compose the INEL are: Bingham, Bonneville, Butte, Clark, and Jefferson.

If the facility is proposed to be located in an area listed in Appendix VI of Part 264, the owner or operator shall demonstrate compliance with the seismic standard. The major portion of the INEL lies in Butte County, which is not on the list. This means that if the facility were located in Butte County, it is assumed to be in compliance with the seismic requirements. If it turns out that the proposed location of the facility is in a county listed in Appendix VI of Part 264, then this requirement will need to be addressed.

\subsubsection{Floodplains}

40 CFR 264.10, "Applicability," states that the floodplain restrictions apply only to TSD tacilities subject to regulation under Subparts I through $O$ of this part. Subpart I addresses the use and management of containers and Subpart $O$ addresses incinerators; the MLLWTF will be subject to these subparts, so floodplain restrictions will apply. 
TSD facilities, subject to this regulation, are not permitted in the 100-year floodplain unless one of three conditions are met:

- The facility is protected, via dikes or other equivalent measures, from washout during a 100-year flood

- All hazardous materials can be removed to safe ground prior to flooding

- It can be demonstrated that no adverse effects to human health and the environment will occur should flood waters reach the waste.

Although the 100-year floodplain standard explicitly addresses significant threats of flooding to facilities, the standard does not specifically define the types of locations that are especially flood prone. Certain land areas that are likely to be located in a 100-year floodplain include areas protected by flood control structures, coastal high hazard areas, channel encroachment areas, and wetlands.

\subsubsection{Salt Dome Formations, Salt Bed Formations, Underground Mines, and Caves}

The placement of any noncontainerized or bulk liquid hazardous waste in any salt dome formation, salt bed formation, underground mine, or cave is prohibited, except for the DOE-New Mexico Waste Isolation Pilot Plant. Of the aforementioned geologic structures, caves are located at the INEL; however, since the MLLWTF will not be involved with the placement of noncontainerized or bulk liquid hazardous waste in these structures, this requirement is not applicable.

\subsection{Wild and Scenic Rivers Act (16 U.S.C. 1273 et seq.)}

Section 7 of the Wild and Scenic Rivers Act prohibits the regional administrator from assisting, by license or otherwise, the construction of any water resources project that would have a direct, adverse effect on the values for which a national wild and scenic river was established. Generally, the EPA interpretation of this obligation is to discourage the siting of TSD facilities in these riverine areas and adjoining lands to the extent that such facilities may impact these protected areas. The rivers located on the INEL are the Big Lost River, Little Lost River, and Birch Creek. None of these have been designated as a wild and scenic river, so this requirement is not applicable to the INEL. 


\subsection{National Historic Preservation Act of 1966 (16 U.S.C. 470 et seq.)}

Section 106 of the National Historic Preservation Act and implementing regulations (36 CFR 800) require the regional administrator, before issuing a license, to adopt measures when feasible to mitigate potential adverse effects of the licensed activity and properties listed or eligible for listing in the National Register of Historical Places.

The DOE, Advisory Council on Historic Preservation (ACHP), and Idaho State Historic Preservation Officer (SHPO) require an archeological survey/consultative review of all projects that affect undisturbed areas. This requirement is applicable to the INEL because historic and prehistoric artifacts have beer 'ound here in the past. The report, Archeological Investigations on the Idaho National Engineering Laboratory, 1984-1985, can be used as a preliminary screening mechanism for sites, but an archeological survey will need to be performed on all candidate sites.

\subsection{Endangered Species Act of 1973 (16 U.S.C. 1531 et seq.)}

Section 7 of the Endangered Species Act and implementing regulations (50 CFR, Parts 17 and 402) require the regional administrator to ensure that any act authorized by the EPA is not likely to jeopardize the continued existence of any endangered or threatened species or adversely affect its critical habitat. Generally, the EPA interpretation of this obligation is to prohibit the siting of TSD facilities within endangered or threatened species habitat. An ecological survey will need to be performed on candidate sites, along with consultation from the United States Fish and Wildlife Service (FWS), Idaho Fish and Game, and Bureau of Land Management (BLM) to determine if a critical habitat exists at a proposed location. Appendix $\mathrm{C}$ contains a list of Federal threatened, endangered, and candidate species and State species of concern that may occur on the INEL.

\subsection{Fish and Wildlife Coordination Act (16 U.S.C. 661 et seq.)}

The Fish and Wildlife Coordination Act requires that the regional administrator, before issuing a permit proposing or authorizing the impoundment, diversion, or other control or modification of any body of water, consult with the appropriate State agency exercising jurisdiction over wildlife resources to conserve those resources. This requirement is applicable if the MLLWTF project will impound, control, or modify the waters of a stream or other body of water that is greater than or equal to 10 acres in surface area.

\subsection{Coastal Zone Management Act (16 U.S.C. 1451 et seq.)}

The Coastal Zone Management Act requires that all Federal activities in coastal areas (see definitions in Appendix A) be consistent with approved State coastal zone management programs to the maximum extent possible. The INEL is not a coastal area, so this requirement does not apply. 


\subsection{Wilderness Protection Act of 1964 (16 U.S.C. 1131 et seq.)}

The Wilderness Protection Act designates wilderness areas within public lands that include national parks, national wildlife refuges, national forests, and BLM lands. Designated wilderness areas cannot be used as sites for TSD facilities without congressional approval. The aforementioned areas are not located on the INEL, so this requirement does not apply.

\subsection{Toxic Substances Control Act of 1976 (15 U.S.C. 2601 et seq.)}

The Toxic Substances Control Act (TSCA) contained in 40 CFR Subchapter R is applicable to the MLLWTF for the storage and treatment of polychlorinated biphenyls (PCBs) specifically contained in 40 CFR Part 761, "Polychlorinated Biphenyls (PCBs) Manufacturing, Processing, Distribution in Commerce, and Use Prohibitions." Location standards apply to the storage for disposal of PCBs and PCB items at concentrations of $50 \mathrm{ppm}$ or greater. These standards are contained in 40 CFR 761.65 (b) (1) (v), "Storage for Disposal," and prohibit locations at sites "below the 100 -year flood water elevation."

\subsection{Clean Air Act of 1970 (42 U.S.C 7401 et seq.)}

The 1977 amendments to the Clean Air Act used EPA's three-class zoning system, i.e., Class I, II, and III areas, which provide for certain allowable increments of additional pollution in each. Section 162 defines all national parks and wilderness areas above a certain size (5000 to 6000 acres, depending on the type of park) as Class I areas which cannot be redesignated. Section 169A designed a program for "the prevention of any future, and the remedying of any existing, impairment of visibility" in Class I areas from man-made air pollution. In the vicinity of the INEL, Craters of the Moon National Monument, Yellowstone National Park, and Grand Teton National Park are Class I air quality areas. Development that impairs the visibility of these areas will not be eligible for an air quality permit from the State of Idaho. In siting the MLLWTF, a determination of potential emissions from the facility must be made and used to site the facility such that there will be no visibility impairment to any Class I area.

\subsection{Wetlands (Executive Order 11990)}

Executive Order 11990 entitled, "Protection of Wetlands," directs Federal agencies to avoid undertaking or providing assistance for new construction of projects located on federally-owned wetlands (see definitions in Appendix A) unless there is no practical alternative. In cases where there is no alternative site, all measures must be taken to minimize harm to the wetland. DOE has issued regulations in 10 CFR 1022 that establish procedures for compliance with this order. Wetlands may occur at the INEL during high water stages of the Big Lost River. These areas will need to be identified and eliminated from the siting investigation. 


\subsection{Floodplains (Executive Order 11988)}

Executive Order 11988, entitled "Floodplain Management," requires governmental agencies to avoid, to the extent possible, impacts associated with the occupancy and modification of floodplains. This order is also implemented in 10 CFR 1022. Since floodplains are more strictly regulated under TSCA and RCRA, this order will have no additional impact on siting the MLLWTF on the INEL. 


\section{DOE Order 6430.1A, General Design Criteria}

The purpose of this order is to "provide general design criteria (GDC) for use in the acquisition of the Department's facilities and to establish responsibilities and authorities for the development and maintenance of these criteria." It is DOE policy that the planning, design, and construction of DOE facilities be performed in a manner that will satisfy all applicable executive orders, Federal laws, and regulations. The majority of this order is based on considerations to be observed during siting, and not on actual requirements.

\subsection{Section 0200, Site Development, Subpart 1, "Facility Siting"}

The following conditions and requirements shall be considered during site selection for a new facility:

- Programmatic and operating efficiency

- Natural topographic and geologic conditions

- Existing cultural, historic, and archaeological resources

- Endemic plant and animal species

- Existence of known RCRA and/or Comprehensive Environmental Response, Compensation, and Liability Act (CERCLA) sites

- Special siting requirements for facilities containing, using, or processing hazardous materials

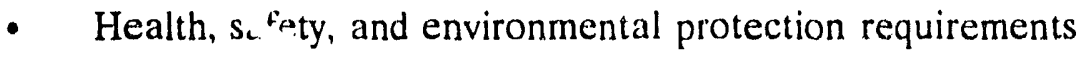

- Indoor air quality impacts

- Hazardous operations and consequences of potential accidents in adjacent facilities

- Natural hazards

- Physical protection requirements

- Security and safeguard requirements

- Adequacy of existing or planned support and service facilities, including utilities, roads, and parking areas 
- Interrelationships between facilities and aesthetic compatibility

- Energy conservation requirements

- Impact of site selection.

This section states that the above conditions be considered when siting a new facility, but does not specifically prohibit any locations.

\subsubsection{Radiological Siting Guidelines}

For those facilities in which racioactive materials are processed, used, or stored, the acceptability of the site shall be evaluated in terms of potential radiological consequences. The accidents to be consider :d are those attributable to both operational events and natural phenomena.

The following siting guidelines apply to offsite individuals receiving maximum dose from exposure to internally-deposited radioactive materials and/or radiation from external sources. Guidelines are based on a 50-year committed dose equivalent. The maximum calculated dose shall not exceed $25 \mathrm{rem}$ to the whole body, $300 \mathrm{rem}$ to the thyroid, $300 \mathrm{rem}$ to the bone surface, $75 \mathrm{rem}$ to the lung, or $150 \mathrm{rem}$ to any other organ. If multiple organs receive doses from the same exposure, the effective dose equivalent from all sources shall not exceed $25 \mathrm{rem}$ when calculated using the weighting factors defined by the International Commission on Radiological Protection (ICRP). Report No. 26. These guidelines will be used in siting the MLLWTF.

\subsection{Section 0285, Solid Waste Systems, Subpart 2, "Site Selection"}

Site selection is the most critical step in establishing TSD facilities for hazardous, nonhazardous, and low-level radioactive waste. The following conditions and requirements shall be considered during the selection of solid waste TSD sites:

- Existing groundwater and surface water conditions

- Soil, geologic, and topographic features

- Solid waste types and quantities

- Social, geographic, and economic factors

- Aesthetic and environmental impacts.

This section states that the above conditions be considered during site selection, but does not specifically prohibit any locations. 


\subsubsection{Environmentally Sensitive Area}

The following environmentally sensitive areas shall be avoided or receive lowest siting priority for treating, storing, and disposing of hazardous, nonhazardous, and radioactive solid waste:

- Wetlands

- Areas within the 500-year floodplain

- Permafrost areas

- Critical habitats of endangered species

- Recharge zones of sole-source aquifers

- Watersheds for domestic water supply.

This section states that the above locales be avoided or given lowest priority. Since all but the 500-year floodplain are already restricted by other laws or do not apply to the INEL (e.g., permafrost areas), this will have little impact on siting of the MLLWTF. The 500-year floodplain will need to be considered when siting the proposed MLLWTF.

\subsubsection{Fault Zones and Karst Terrain}

When potential sites are screened for location of new solid waste TSD facilities, seismic zones and karst (limestone formation) terrain shall be avoided unless site-specific evaluations demonstrate minimum potential for contamination of surface water, groundwater, and other environmental resources. The INEL has no karst terrain, but seismic zones will need to be investigated further when siting the proposed MLLWTF.

\subsubsection{Cost Effectiveness}

Life-cycle cost (LCC) analysis shall be performed during site selection for TSD facilities. LCC analysis shall include site reclamation costs.

\subsubsection{Sites Traversed by Utilities}

Sites traversed by buried pipe utilities shall not be used for TSD facilities unless the relocation or protection of these utilities is economically feasible. Buried pipe utility trenches can serve as a pathway for the migration of contaminants. This restriction does apply to the proposed MLLWTF. 


\subsubsection{Characteristics and Availability of Soil Cover}

The characteristics and availability of onsite soil cover shall be considered with respect to site operation and performance requirements.

\subsubsection{Site Access}

Sites shall be accessible to service and refuse collection vehicles by all-weather road extensions from primary road systems.

\subsubsection{Effects on Other Facilities}

Sites that would adversely affect operation of other facilities shall be avoided. The following effects shall be considered:

- Vehicular traffic

- $\quad$ Noise

- Litter

- $\quad$ Bird strike

- Vectors.

- Other nuisance conditions.

This restriction does apply to the proposed MLLWTF. 


\section{CONCLUSIONS}

The physical location of a TSD facility directly influences the potential for impacting human health and the environment. Physical locations refer to the geologic, hydrologic, and pedologic characteristics of a site, as well as adjoining lands, surface water, and ground water that may be impacted in the event that hazardous and/or radiological constituents are released from the facility. A 1983 EPA study concluded that proper site selection and appropriate hydrologic and geologic conditions are important factors in maintaining long-term protection of the environment.

The first step taken in selecting a site for the proposed MLLWTF is to assume that the facility would be located at the INEL and thus, the region of interest is the 890 square miles encompassing the INEL. The INEL is located near Idaho Falls, in the Eastern Snake River Plain physiographic province. The dominant geologic features of the Snake River plain were formed by volcanism. However, the plain is bordered by basin and range mountains that were created by normal faults.

The siting of the proposed MLLWTF will be accomplished by excluding all sites on the INEL that do not meet the mandatory requirements (i.e., "Go/No-Go"). The remaining sites will then be rated according to various differentiating criteria that will impact site selection, but that are not strict requirements. Risk factors will be assigned to these criteria based on their probability and seriousness, and will be used in the final decision-making process.

The following is a list of mandatory requirements applicable to the INEL for the location of the proposed MLLWTF, as determined from EPA regulations and DOE orders.

- The MLLWTF cannot be located at a site below the 100 -year tlood water elevation if the facility contains PCBs or PCB items with concentrations of 50 ppm or greater (Section 2.8)

- If the MLLWTF does not store PCBs or PCB items, but does store RCRA hazardous or mixed waste, it cannot be located in the 100-year floodplain unless it meets one of the three conditions discussed in Section 2.1.2

- If the MLLWTF is located in Bingham, Bonneville, Clark, or Jefferson county, portions of the facility where treatment, storage, or disposal of hazardous waste will be conducted cannot be located within 61 meters (200 feet) of a fault that has had displacement during the last 10,000 years (Section 2.1.1)

- The MLLWTF cannot have any direct adverse impacts on sites listed or eligible for listing on the National Register of Historic Places (Section 2.3)

- The MLLWTF cannot be located within an endangered or threatened species habitat (Section 2.4) 
- The MLLWTF cannot be located in a site such that air emissions from the facility will visibly impair any Class I ai quality area (Section 2.9 )

- The MLLWTF will be locatid so that the maximum calculated duse from exposure to internally deposited radioactive materials and/or radiation from external wources th offsite individuals shall not exceed the limits identified in Section 3.1.1

- The MLLWTF cannot be located or a site traversed by buried pipe utilities unless it meets the requirements in Section 3.2 .4

- The MLLWTF cannot be located on a site that would adversely affect the operation of other facilities (Section 3.2.7).

The following an additional requirements that should be considered when siting the proposed MLLWTF.

- The location of existing RCRA and/or CERCLA sites shall be avoided when siting the MLLWTF (Section 3.1)

- The adequacy of existing or planned support and service facilities stall be considered when siting the MLLWTF (Section 3.1)

- The 500-year floodplain shall be avoided when siting the MLLWTF (Section 3.2.1)

- Wetlands shall be avoided when siting the MLLWTF (Section 2.10)

- Seismic zones shall be avoided when siting the MLLWTF (Section 3.2.2)

- The remoteness frorn site boundaries shall be considered when siting the MLLWTF

- The distance to waste generators shall be considered when siting the MLLWTF

- The effects of Department of Transportation (DOT) regulations on the transport of waste to and from the MLLWTF shall be considered when siting the MLLWTF

- The slope of the land surface and corresponding energy available for erosion shall be considered when siting the MLLWTF

- The distance from volcanic exclusion zones shall be considered when iting the MLLWTF

- The commuting distance to the MLLWTF shall be considered when siting the MLLWTF 
- The costs $v f$ installing new utilities and roads shall be considered when siting the MLLWTF

- The ability of the site to be fully characterized (i.e., not a complex geological location) shall be considered when siting the MLLWTF

- The location of unexploded ordnance should be considered when siting the MLLWTF

- The co-location of the MLLWTF with other proposed facilities at the INEL shall be considered when siting the MLLWTF.

The final decision-making process will be a combination of excluding all sites that do not meet the mandatory requirements, and ranking all remaining sites, with respect to each other, by their abilities to meet the differentiating criteria. This process will be developed in the final siting report for the MLLWTF. 


\section{BIELIOGRAPHY}

56 FR 77, "Location Standards for Hazardous Waste Facilities," U.S. Environmental Protection Agency, 18024, Aspril 22, 1991.

Brynda, W. J., C. H. Scarlett, G. E. Tanguay, and P. R. Lobner, Nonreactor Nuclear Facilities: Standards and Criteria Guide, DOE/TIC-11603-Rev.1, September 1986, pp. 2-1 through 2-11.

Code of Federal Regulations, 40 CFR 761, "Polychlorinated Riphenyls (PCBs) Manufacturing, Distribution in Commerce, and Use Prohibitions," Office of the Federal Register, July 1990.

Code of Federal Regulations, 40 CFR 270, "EPA-Administered Permit Programs--The Hazardous Waste Permit Program," Office of the Federal Register, July 1990.

Code of Federal Regulations, 40 CFR 264, "Standards for Owners and Cperators of Hazardous Waste Treatment, Storage, and Disposal Facilities," Office of the Federal Register, July 1990.

Combined NRC-EPA. Siting Guidelines for Disposal of Commercial Mixed Low-level Radioa tive and Hazardous Waste, 9480.00-14, U.S. Environmental Protection Agency, Office of Solid Waste, June 29, 1987.

Cook, J. R., M. W. Grant, and O. O. Towler, New Low-Level Radioactive Waste Storage/Disposal Facilities at the Savannah River Plant, DPST-85-862, April 1987, pp. 1-41.

Criteria for Identifying Areas of Vulnerable Hydrogeology Under RCRA, Statutory Intervietive Guidance, 530-SW-86-022, U.S. Environmental Protection Agency, Ottice of Solid Waste. July 1986.

Draft Environmental Impact Statement for the Siting, Constuction, and Operation of New Production Reactor Capacity, DOE/EIS-0144D, U.S. Department of Energy, Office of New Production Reactors, April 1991.

Permit Writer's Guidance Manual for Hazardous Waste Land Treatment, Storage, and Disposal Facilities; Phase I-Criteria for Location Acceptability and Existing Applicable Regulations. EPA-530-SW-85-024, U.S. Environmental Protection Agency, Office of Solid Waste and Emergency Response, February 1985. 
Regulatory Development Plan, Location Standards for RCRA Hazardous Waste Facilities Regulatory Development Plan, PB87-162954, U.S. Environmental Protection Agency, Office of Solid Waste, December 1982.

Sivill, R. L.. Advanced Liquid Metal Reactor Site Selection Criteria Report, EGG-NPD-8837, January 1990

Sivill, R. L., Reference Site Selection Report for the Advanced Liquid Metal Reactor at the Idaho National Engineering Laboratory, EGG-NPD-8836, March 1990.

Spry, M. J., K. S. Moor, S. J. Maheras, and H. K. Peterson, Si:e Selection Report for the New Production Reactor at the Idaho National Engineering Laboratory, EGG-NPR-8517, Rev. 1, July 1989.

Standards Applicable to Owners and Operators of Hazarduus Waste Treatment, Storage, and Disposal Facilities Under RCRA, Subtitle C, Section 3004, "General Facility Standards for Location of Facilities (40 CFR 264.18)," EPA-1941.32, U.S. Environmental Protection Agency, Office of Solid Waste, December 1980.

U.S. Department of Energy, "General Design Criteria," DOE 6430.1A, April 6, 1989.

U.S. Department of Energy. "Real Property and Site Development Planning." DOE 4300.1B. July $1,1987$.

U.S. Department of Energy, "Site Development Planning," DOE 4320.1B, Jan'sary 7, 1991. 


\title{
Appendix A
}

\author{
Definitions
}




\section{Appendix A}

\section{Definitions}

\section{Coastal Zone}

The coastal waters (including the lands therein and thereunder), strongly influenced by each other and in proximity to the shorelines of the several coastal states; includes islands, transitional and intertidal areas, sait marshes, wetlands, and beaches (16 U.S.C. 1453).

\section{Displacement}

The relative movement of any two sides of a fault measured in any direction (40 CFR 264.18).

Fault

A fracture along which rocks on one side have been displaced with respect to those on the other side (40 CFR 264.18).

\section{Holocene}

The most recent epoch of the Quaternary period, extending from the end of the Pleistocene to the present, i.e., during the last 10,000 years (40 CFR 264.18).

\section{Pleistocene}

An epoch of the Quaternary period, beginning two to three million years ago and lasting to the start of the Holocene.

\section{Polychlorinated Biphenyl (PCB)}

Any chemical substance that is limited to the biphenyl molecule that has been chlorinated to varying degrees, or any combination of substances that contains such substance (40 CFR 761.3).

\section{PCB Item}

Any $\mathrm{PCB}$ article, article container, container, or equipment that deliberately or unintentionally contains or has a part of it any PCB or PCBs (40 CFR 761.3). 


\section{Quaternary}

The second period of the Cenozoic era, following the Tertiary, beginning two to three million years ago and extending to the present.

\section{Volcanic Exclusionary Zone}

Outside "recent" lava flows, at least 3 miles from "older" vents, and at least 5 miles from "recent" vents (Sivill, 1990).

\section{Washout}

The movement of hazardous waste from the active portion of the facility as a result of flooding (40 CFR 264.18).

\section{Wetland}

Land areas where the water table is at, near, or above the land surface long enough to promote the formation of hydric soils and to support the growth of hydrophytes.

\section{0-Year Flood}

A flood that has a $1 \%$ chance of being equaled or exceeded in any given year (40 CFR 264.18).

\section{0-Year Floodplain}

Any land area that is subject to a $1 \%$ chance of flooding in any given year from any source (40 CFR 264.18). 
Appendix B

Geologic Timetable 


\section{Appendix B}

\section{Geologic Timetable}

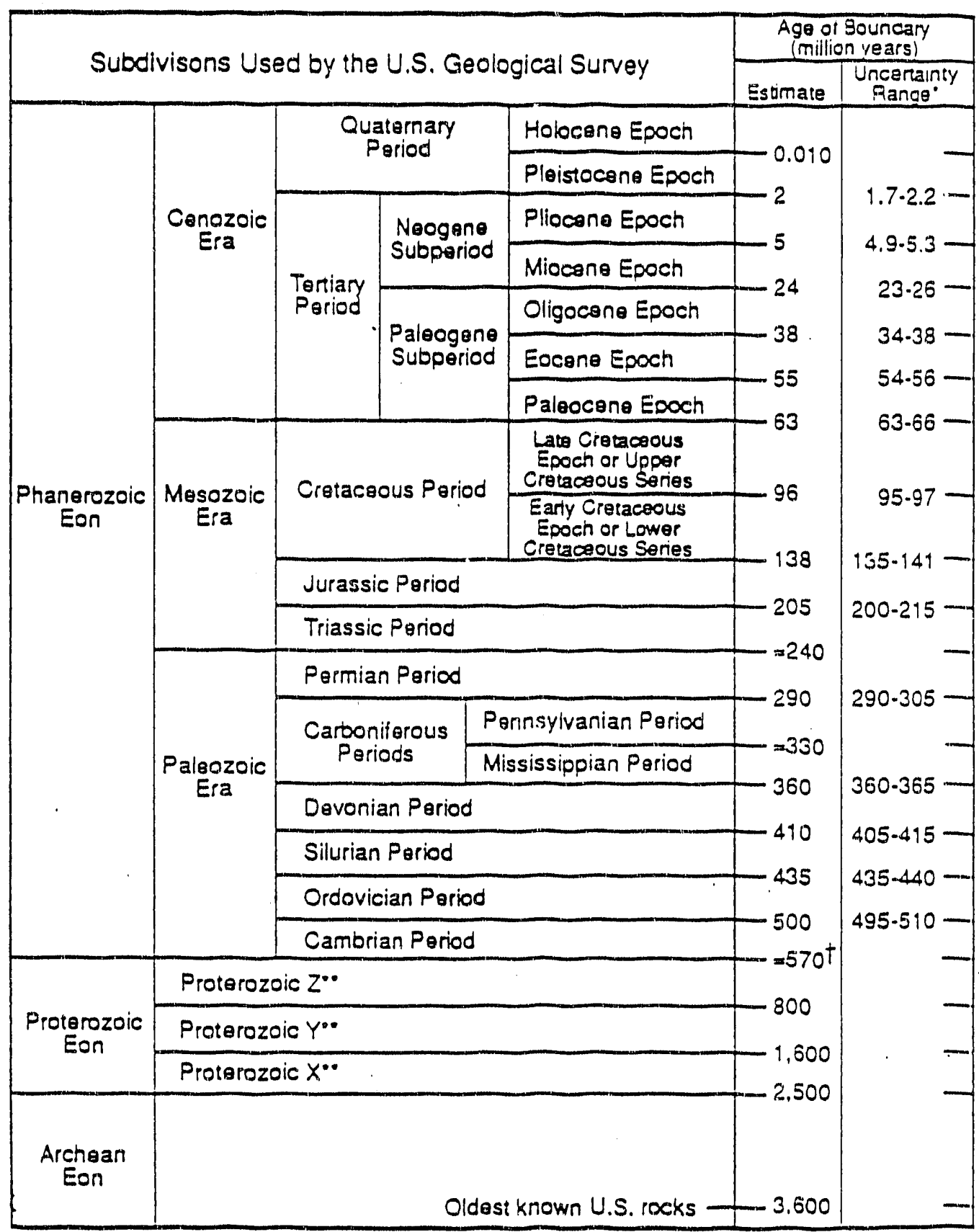

- Ranges raflect uncertaintes of isotopic and biostratigraphic age assignments. Decay constants and isotope ratos employed are cited in Steiger ano Jager (1977).

t Rocks older than 570 million years are also called Precambrian, a time term without speciñc rank. -. Time terms without specific rank.

Source: Modified from American Geological Institute 1982 


\section{Appendix C}

Federal Threatened, Endangered, and Candidate Species and State Species of Special Concern on the INEL 


\section{Appendix C}

\section{Federal Threatened, Endangered, and Candidate. Species and State Species of Special Concern on the INEL}

\begin{tabular}{|c|c|c|c|}
\hline Common Name & Scientific Name & $\begin{array}{l}\text { Federal } \\
\text { Status }\end{array}$ & $\begin{array}{l}\text { State } \\
\text { Status }\end{array}$ \\
\hline $\begin{array}{l}\text { Plants } \\
\text { Painted milk-vetch } \\
\text { Wooly pod milk-vetch } \\
\text { Oxytheca } \\
\text { Pincushion cactus } \\
\text { Large-lowered gymosteris }\end{array}$ & $\begin{array}{l}\text { Astragnlus ceramicus } \\
\text { Astragnlus pursitii } \\
\text { Oxytheca dendroidea } \\
\text { Coryphantha missouriensis } \\
\text { Gumosteris nudicaulis }\end{array}$ & $\begin{array}{l}C 2 \\
C 2 \\
N L \\
N L \\
N L\end{array}$ & $\begin{array}{l}\text { NL } \\
\text { NL } \\
\text { SC } \\
\text { SC } \\
\text { SC }\end{array}$ \\
\hline $\begin{array}{l}\text { Birds } \\
\text { Peregrine falcon } \\
\text { Merlin } \\
\text { Gyrialcon } \\
\text { Osprey } \\
\text { Bald eagle } \\
\text { Swainson's hawk } \\
\text { Feruginous hawk } \\
\text { Burrowing owvl } \\
\text { White-faced ibis } \\
\text { Long-billed curlew }\end{array}$ & $\begin{array}{l}\text { Falco peregrinus } \\
\text { Falco columionius } \\
\text { Falco rusticolus } \\
\text { Pandion haliaetus } \\
\text { Halizetus leucocephalus } \\
\text { Buteo suninsont } \\
\text { Buteo regalis' } \\
\text { Athene Cuniculariab } \\
\text { Plegndis chïli } \\
\text { Numenius americanus }\end{array}$ & $\begin{array}{l}E \\
N L \\
N L \\
N L \\
E \\
C 2 \\
C 2 \\
N L \\
N L \\
C 2\end{array}$ & $\begin{array}{l}\text { SC } \\
\text { SC } \\
\text { SC } \\
\text { SC } \\
\text { SC } \\
\text { SC } \\
\text { SC } \\
\text { SC } \\
\text { SC } \\
\text { SC }\end{array}$ \\
\hline $\begin{array}{l}\text { Mammals } \\
\text { Townsend's western big-eared bat } \\
\text { Bobcat }\end{array}$ & $\begin{array}{l}\text { Plecotus townsendi } \\
\text { Lunx rufus }\end{array}$ & $\begin{array}{l}\mathrm{C} 2 \\
\mathrm{NL}\end{array}$ & $\begin{array}{l}\text { NL } \\
\text { SC }\end{array}$ \\
\hline
\end{tabular}

aStatus codes: $C_{2}=$ Category 2 species; $E$ = endangered species; $N L=$ not listed; $S C=$ species of special concern; $T=$ threatened species.

brown to occur on the NPR site.

Source: Staley 1989. 


\section{Health and Safety Criteria Overview for the Mixed and Low-Level Waste Treatment Facility at the Idaho National Engineering Laboratory}

R. M. Neupauer

Published March 1992

Idaho National Engineering Laboratory

EG\&G Idaho, Inc. Idaho Falls, Idaho 83415 

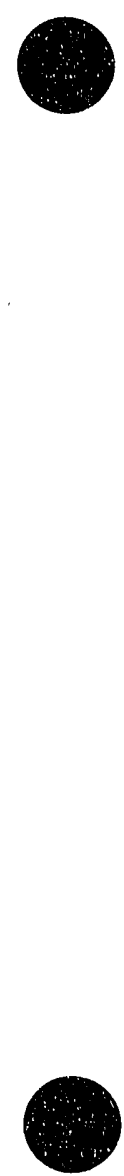

- 


\section{CONTENTS}

1. INTRODUCTION $\ldots \ldots \ldots \ldots \ldots \ldots \ldots \ldots \ldots \ldots \ldots \ldots \ldots \ldots \ldots \ldots$

2. GENERAL HEALTH AND SAFETY STUDY $\ldots \ldots \ldots \ldots \ldots \ldots \ldots \ldots \ldots$

2.1 Facility-wide Health and Safety Considerations $\ldots \ldots \ldots \ldots \ldots \ldots \ldots \ldots \ldots$

2.2 Chemical-specific Health and Safety Considerations $\ldots \ldots \ldots \ldots \ldots \ldots \ldots \ldots$

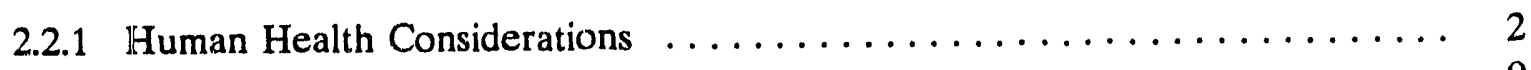

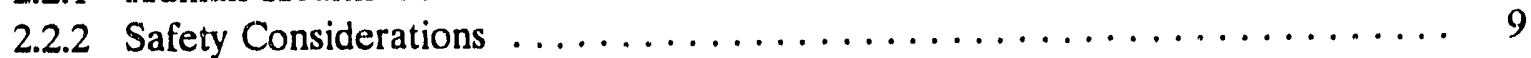

3. DETAILED HEALTH AND SAFETY STUDY $\ldots \ldots \ldots \ldots \ldots \ldots \ldots \ldots \ldots \ldots$

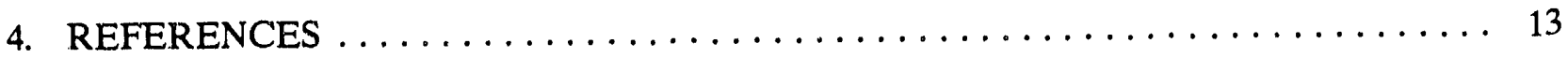

\section{TABLES}

1. Health and safety concerns for candidate chemical constituents (adapted from Sax and

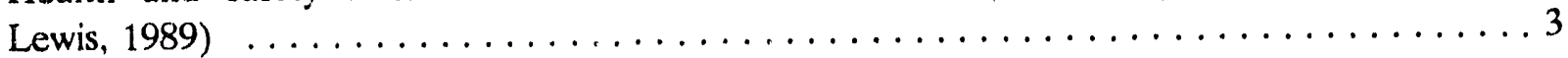

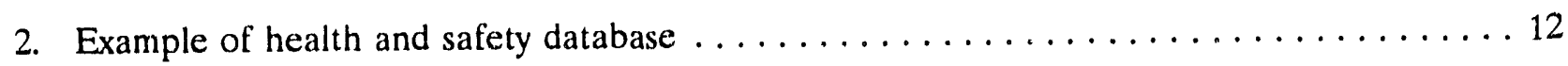




\section{Health and Safety Criteria Overview for the Mixed and Low-Level Waste Treatment Facility at the Idaho National Engineering Laboratory}

\section{INTRODUCTION}

The operations occurring at a waste treatment facility involve potential health and safety risks, which must be considered in the design of any facility. All candidate waste streams and treatment technologies have some health or safety risks associated with them. Knowledge of these risks may affect the selection of operations to be conducted at the facility. Safety hazards may result in accidents that could prevent operation of the facility, cause harm to personnel, or increase the cost of operation; therefore, the facility should be designed to minimize safety risk. To adequately address this concern, health and safety issues must be investigated for the potential waste streams and treatment technologies at the proposed Mixed and Low Level Waste Treatment Facility (MLLWTF) to be located at the Idaho National Engineering Laboratory (INEL).

A study of health and safety issues for the proposed facility has been initiated. The study is divided into two parts - a general study of the health and safety considerations for the overall facility; and a detailed study of potential health and safety issues for the candidate waste streams and treatment technologies. The purpose of the general study is to identify potential health and safety problems associated with the entire facility, such as personnel exposure, waste handling, and waste storage. The purpose of the detailed study is to develop health and safety criteria to assess potential waste streams and treatment technologies and to analyze these waste streams and technologies according to the selected criteria. The information obtained in the study will be used in a treatability study for the candidate wastes streams and in the treatment selection process for the candidate technologies.

Health and safety criteria that may be considered in the cletailed study include, but are not limited to, personnel exposure to chemicals and ionizing radiation, carcinogenicity, noise, heat stress, cold exposure, oxygen deficiency, biological hazards, safety and electrical hazards, fire and explosion hazards, reactivity of chemicals, safe handling practices, and ergonomic stress. Additional criteria, if determined to be necessary, may be included during the course of the study. 


\section{GENERAL HEALTH AND SAFETY STUDY}

Health and safety considerations that may affect the potential operations at the proposed MLLWTF have been identified in the general study. These considerations were separated into two groups: those that apply to the overall facility and those that apply to specific chemicals in the candidate waste streams. The results of the general health and safety study are presented in the following sections. Although many health and safety issues have been identified in the study, proper design of the facility can alleviate the potential problems; therefore, based on the currently available information, no irresolvable issues have been identified.

\subsection{Facility-wide Health and Safety Considerations}

Certain health and safety considerations that apply to the entire facility will be discussed in this section. To minimize personnel exposure, air sampling and personnel monitoring should be conducted for radioactivity, heavy metals, and organic vapors. Also, proper industrial hygiene practices should be implemented, such as correct labeling, appropriate training, special eating, areas, and use of the necessary personal protective equipment (PPE). The facility should have an emergency plan that outlines procedures to be followed in the event of a spill, fire, or other emergency. In addition, the methods for transporting waste from storage and for transferring waste from storage containers to treatment processes should be designed to minimize human exposure. Heavy drums and containers should be lifted and handled using appropriate equipment and waste should be automatically fed into the treatment machinery wherever possible. ${ }^{a}$

\subsection{Chemical-specific Health and Safety Considerations}

To evaluate the chemical-specific considerations, each chemical that has been identified in the Engineering Design Files (EDF) for the candidate mixed waste streams was analyzed for potential health and safety problems. Only the mixed waste streams were analyzed in the general study. Low level and mixed waste streams both present hazards due to radioactivity, which were addressed in the facility-wide considerations. The hazardous chemicals in mixed waste pose additional health and safety risks which are addressed in the chemical-specific considerations. Table 1 summarizes health and safety hazards for each chemical.

\subsubsection{Human Health Considerations}

Many chemicals in the candidate wastes are harmful to human health. Each of the chemicals have been analyzed for human health considerations including toxic or poisonous effects, irritants, carcinogenicity, and evolution of toxic or irritating fumes. A toxic effect is any reversible or irreversible noxious effect on the body. Many chemicals are toxic to humans through one or more routes of entry. In a waste treatment facility, the likely routes of entry include inhalation, ingestion, and skin contact. In this study, chemical toxicity is addressed only for these specific routes.

a Private communication with Clorinda M. Lindstrand, James A. Pautler, and Alvin W. Stokes, EG\&G Idaho, Inc., Idaho Falls, Idaho, March 20, 1992. 
Table 1. Health and safety concerns for candidate chemical constituents (adapted from Sax and Lewis, 1989).

\begin{tabular}{|c|c|c|}
\hline Chemical & Health concerns & Safety concerns \\
\hline Acetone & $\begin{array}{l}\text { Moderately toxic by various routes } \\
\text { including inhalation and ingestion; skin } \\
\text { and eye irritant. }\end{array}$ & $\begin{array}{l}\text { Dangerous fire and explosion } \\
\text { hazard; ignites on contact } \\
\text { with chromium trioxide; can } \\
\text { react vigorously with } \\
\text { oxidizing material; } \\
\text { incompatible with air and } \\
\text { nitric acid. }\end{array}$ \\
\hline Arsenic & $\begin{array}{l}\text { Human poison; human carcinogen; emits } \\
\text { highly toxic fumes when heated or on } \\
\text { contact with acid. }\end{array}$ & $\begin{array}{l}\text { Dust form is flammable when } \\
\text { exposed to heat or flame or } \\
\text { by chemical reaction with } \\
\text { powerful oxidizers including } \\
\text { chromium trioxide; dust is } \\
\text { slightly explosive when } \\
\text { exposed to flame; reacts } \\
\text { vigorously on contact with } \\
\text { oxidizing material; } \\
\text { incompatible with halogens, } \\
\text { zinc, chromium trioxide. }\end{array}$ \\
\hline Asbestos & Human carcinogen. & N/A \\
\hline Barium & Can cause poisoning through ingestion. & $\begin{array}{l}\text { Dust is dangerous explosive } \\
\text { when exposed to heat, tlame, } \\
\text { and chemical reactions; } \\
\text { violent or explosive reaction } \\
\text { with water; powder may } \\
\text { ignite or explode in air or } \\
\text { other oxidizing gas; } \\
\text { incompatible with acids. }\end{array}$ \\
\hline Barium chloride & $\begin{array}{l}\text { Human poison through ingestion; emits } \\
\text { toxic fumes of } \mathrm{Cl}^{-} \text {wher heated to } \\
\text { decomposition. }\end{array}$ & N/A \\
\hline Bismuth & $\begin{array}{l}\text { Poisonous to humans; emits toxic fumes } \\
\text { when reacting with acid. }\end{array}$ & $\begin{array}{l}\text { Flammable when exposed to } \\
\text { flame; incompatible with } \\
\text { acids and chlorine. }\end{array}$ \\
\hline
\end{tabular}


Table 1. (continued).

\begin{tabular}{|c|c|c|}
\hline Chemical & Health concerns & Safety concerns \\
\hline Cadmium & $\begin{array}{l}\text { Human poison through inhalation; } \\
\text { experimental carcinogen; emits toxic } \\
\text { fumes when strongly heated. }\end{array}$ & $\begin{array}{l}\text { Dust is flammable and } \\
\text { explosive when exposed to } \\
\text { heat, flame, or by chemical } \\
\text { reaction with oxidizing } \\
\text { agents, metals, zinc, and } \\
\text { selenium; dust ignites } \\
\text { spontaneously in air. }\end{array}$ \\
\hline Cadmium chloride & $\begin{array}{l}\text { Human poison through inhalation, } \\
\text { ingestion, and skin contact; experimental } \\
\text { carcinogen; emits toxic fumes of } \mathrm{Cl}^{-} \\
\text {when heated to decomposition. }\end{array}$ & $\begin{array}{l}\text { Reacts violently with } \\
\text { potassium. }\end{array}$ \\
\hline Cadmium nitrate & $\begin{array}{l}\text { Human poison through ingestion; emits } \\
\text { toxic fumes of } \mathrm{Cd} \text { and } \mathrm{NO}_{x} \text { when heated } \\
\text { to decomposition. }\end{array}$ & N/A \\
\hline Cadmium sulfate & $\begin{array}{l}\text { Human poison through ingestion; emits } \\
\text { toxic fumes of } \mathrm{Cd} \text { and } \mathrm{SO}_{x} \text { when heated } \\
\text { to decomposition. }\end{array}$ & N/A \\
\hline Chromium & $\begin{array}{l}\text { Human poison through ingestion; } \\
\text { suspect carcinogen. }\end{array}$ & $\begin{array}{l}\text { Powder explodes } \\
\text { spontaneously in air; ignites } \\
\text { and is potentially explosive in } \\
\text { atmospheres of carbon } \\
\text { dioxide; incompatible with } \\
\text { oxidants. }\end{array}$ \\
\hline Chromium trioxide & $\begin{array}{l}\text { Human poison through ingestion; skin } \\
\text { irritant; human carcinogen. }\end{array}$ & $\begin{array}{l}\text { Powerful oxidizer; ignites on } \\
\text { contact with methanol; reacts } \\
\text { explosively with organic } \\
\text { materials or solvents; reacts } \\
\text { violently with selenium. }\end{array}$ \\
\hline Chromium-Hex & N/A & N/A \\
\hline Copper & N/A & $\begin{array}{l}\text { Ignites on contact with } \\
\text { chlorine; reacts violently with } \\
\text { hydrogen sulfide in air. }\end{array}$ \\
\hline Cresol & $\begin{array}{l}\text { Moderately toxic through ingestion and } \\
\text { skin contact; emits toxic and irritating } \\
\text { fumes when heated to decomposition. }\end{array}$ & $\begin{array}{l}\text { Flammable when exposed to } \\
\text { heat or flame; vapor is } \\
\text { slightly explosive when } \\
\text { exposed to heat and flame; } \\
\text { reacts violently with nitric } \\
\text { acid; can react vigorously } \\
\text { with oxidizing material. }\end{array}$ \\
\hline
\end{tabular}


Table 1. (continued).

\begin{tabular}{|c|c|}
\hline Chemical & Health concerns \\
\hline Cyanide & $\begin{array}{l}\text { Very poisonous through most routes; } \\
\text { emits toxic vapors when heated to } \\
\text { decomposition or on contact with acid or } \\
\text { water. }\end{array}$ \\
\hline Hydrochloric acid & $\begin{array}{l}\text { Human poison; moderately toxic through } \\
\text { inhalation and ingestion; skin irritant; } \\
\text { emits toxic fumes of } \mathrm{Cl}^{-} \text {when heated. }\end{array}$ \\
\hline Lead & $\begin{array}{l}\text { Human poison through ingestion; } \\
\text { suspect carcinogen; emits highly toxic } \\
\text { fumes with heated to decomposition. }\end{array}$ \\
\hline Mercury & $\begin{array}{l}\text { Human poison through inhalation; } \\
\text { corrosive to skin and eyes; emits toxic } \\
\text { fumes when heated to decornposition. }\end{array}$ \\
\hline Methanol & $\begin{array}{l}\text { Human poison through ingestion and } \\
\text { skin } c \text { ntact; mildly toxic through } \\
\text { inhalation; emits acrid smoke and } \\
\text { irritating fumes when heated to } \\
\text { decomposition. }\end{array}$ \\
\hline Methyl ethyl ketone & $\begin{array}{l}\text { Moderately toxic through ingestion and } \\
\text { skin contact; emits acrid smoke and } \\
\text { fumes when heated to decomposition. }\end{array}$ \\
\hline Methylene chloride & $\begin{array}{l}\text { Moderately toxic through ingestion; } \\
\text { mildly toxic through inhalation; } \\
\text { experimental carcinogen; emits highly } \\
\text { toxic fumes of phosgene and } \mathrm{Cl}^{-} \text {when } \\
\text { heated to decomposition. }\end{array}$ \\
\hline
\end{tabular}

Reacts violently with metals; incompatible with oxidants.

Dangerous fire hazard when exposed to heat, flame, or oxidizers; vapor is explosive when exposed to heat and flame; reacts violently with nitric acid and oxidizing materials; incompatible with metals and oxidants.

Dangerous fire hazard and moderate explosive hazard when exposed to flame.

Forms explosive mixtures with an atmosphere of high oxygen content, potassium, sodium, and sodium potassium; vapor is explosive when exposed to heat and flame; reacts violently with sodium potassium.

Nickel

Human poison through ingestion; experimental carcinogen.

Powders may ignite spontaneously in air; reacts violently with selenium and sulfur; incompatible with oxidants. 
Table 1. (continued).

\begin{tabular}{|c|c|c|}
\hline Chemical & Health concerns & Safety concerns \\
\hline Nitric acid & $\begin{array}{l}\text { Human poison through unspecified } \\
\text { route; corrosive to skin and eyes; emits } \\
\text { highly toxic fumes of } \mathrm{NO}_{x} \text { when heated. }\end{array}$ & $\begin{array}{l}\text { Forms explosive mixtures } \\
\text { with metals; reacts } \\
\text { explosively with hydrocarbons } \\
\text { and sulfur dioxide; ignites on } \\
\text { contact with acetone and } \\
\text { metals; reacts with water or } \\
\text { stream to produce corrosive } \\
\text { fumes; incompatible with } \\
\text { bismuth, cyanides, cresol, } \\
\text { hydrogen sulfide, metals, and } \\
\text { zinc. }\end{array}$ \\
\hline Nitrobenzene & $\begin{array}{l}\text { Human poison through unspecified } \\
\text { route; moderately toxic through ingestion } \\
\text { and skin contact; emits toxic fumes of } \\
\mathrm{NO}_{x} \text { when heated to decomposition. }\end{array}$ & $\begin{array}{l}\text { Oxidant; flammable when } \\
\text { exposed to heat and flame; } \\
\text { moderate explosion hazard } \\
\text { when exposed to heat and } \\
\text { flame; forms explosive } \\
\text { mixtures with nitric acid and } \\
\text { potassium. }\end{array}$ \\
\hline Potassium & $\begin{array}{l}\text { Emits toxic fumes of } \mathrm{K}_{2} \mathrm{O} \text { when heated } \\
\text { to decomposition. }\end{array}$ & $\begin{array}{l}\text { Dangerous fire hazard; } \\
\text { explosion hazard under } \\
\text { proper conditions with } \\
\text { chlorinated hydrocarbons, } \\
\text { hydrochloric acid, metal } \\
\text { halides, metal oxides, nitric } \\
\text { acid, nitrobenzene, and } \\
\text { water. }\end{array}$ \\
\hline Selenium & $\begin{array}{l}\text { Human poison through inhalation; } \\
\text { produces toxic fumes when heated to } \\
\text { decomposition. }\end{array}$ & $\begin{array}{l}\text { Reacts violently with } \\
\text { chromium trioxide, metals, } \\
\text { nickel, nitric acid, sodium, } \\
\text { oxygen, potassium and zinc. }\end{array}$ \\
\hline Silver & $\mathrm{N} / \mathrm{A}$ & $\begin{array}{l}\text { Dust is flammable when } \\
\text { exposed to flame. }\end{array}$ \\
\hline
\end{tabular}


Table 1. (continued).

\begin{tabular}{lll}
\hline \multicolumn{1}{c}{ Chemical } & \multicolumn{1}{c}{ Health concerns } & \multicolumn{1}{c}{ Safety concerns } \\
\hline Sodium & $\begin{array}{ll}\text { Emits toxic fumes when heated to } \\
\text { decomposition; reacts exothermically }\end{array}$ & $\begin{array}{l}\text { Very dangerous fire hazard } \\
\text { when exposed to heat and }\end{array}$ \\
with moisture of body or tissue surfaces & moisture; explosion hazard \\
causing thermal and chemical burns. & when exposed to moisture; \\
& highly reactive; reacts \\
& violently with water to form \\
& sodium hydroxide; reacts \\
& vigorously with oxidizing \\
& materials; reacts \\
& exothermically with halogens, \\
& acids, and halogenated \\
& hydrocarbons; under \\
& appropriate conditions, can \\
& react with moisture, air, \\
& carbon dioxide, chromium \\
& trioxide, hydrogen sulfide, \\
& hydrochloric acid, methyl \\
& chloride, nitric acid,
\end{tabular}

Sodium potassium

Stoddard solvent

Sulfides
Corrosive to skin and eyes; emits toxic fumes of $\mathrm{K}_{2} \mathrm{O}$ and $\mathrm{Na}_{2} \mathrm{O}$ when heated.

Moderately toxic to humans through unspecified route; mildly toxic by inhalation; emits acrid smoke and irritating fumes when heated to decomposition.

Produce highly toxic fumes of $\mathrm{SO}_{x}$ when heated to decomposition; produces hydrogen sulfide, which is toxic, upon contact with moisture or acid.
Dangerous fire and explosion hazard; reacts violently with moisture to form caustics; reacts violently with oxygen, water, halogens, oxidizers, and acids; under proper conditions, will react explosively with moisture, acids, halocarbons, metal halides, and nitrobenzene.

Highly dangerous fire hazard when exposed to heat, flame spark, or oxidizing material; vapor is explosive when exposed to heat or flame.

Flammable when exposed to flame; ignites violently on contact with many powerful oxidizers. 
Table 1. (continued).

\begin{tabular}{|c|c|c|}
\hline Chemical & Health concerns & Safety concerns \\
\hline Tin & N/A & $\begin{array}{l}\text { Dust form is combustible } \\
\text { when exposed to heat or by } \\
\text { spontaneous chemical } \\
\text { reaction with chlorine or } \\
\text { sulfur. }\end{array}$ \\
\hline Toluene & $\begin{array}{l}\text { Mildly toxic through inhalation; produces } \\
\text { acrid smoke and irritating fumes when } \\
\text { heated to decomposition. }\end{array}$ & $\begin{array}{l}\text { Very dangerous fire hazard } \\
\text { when exposed to heat, flame, } \\
\text { or oxidizer; vapor is explosive } \\
\text { when exposed to heat; can } \\
\text { react vigorously with } \\
\text { oxidizing material. }\end{array}$ \\
\hline $\begin{array}{l}1,1,1- \\
\text { Trichloroethane }\end{array}$ & $\begin{array}{l}\text { Moderately toxic through inhalation, } \\
\text { ingestion, and skin contact; emits toxic } \\
\text { fumes of } \mathrm{Cl}^{-} \text {when heated to } \\
\text { decomposition. }\end{array}$ & $\begin{array}{l}\text { Under proper conditions can } \\
\text { undergo hazardous reactions } \\
\text { with potassium, sodium } \\
\text { potassium alloy, sodium } \\
\text { hydroxide, and oxygen. }\end{array}$ \\
\hline Trichloroethylene & $\begin{array}{l}\text { Mildly toxic through inhalation and } \\
\text { ingestion; emits toxic fumes of } \mathrm{Cl}^{-} \text {when } \\
\text { heated to decomposition. }\end{array}$ & $\begin{array}{l}\text { Very dangerous fire hazard } \\
\text { when exposed to heat and } \\
\text { flame; can react violently } \\
\text { with barium, sodium, and } \\
\text { sodium hydroxide. }\end{array}$ \\
\hline Xylene & $\begin{array}{l}\text { Mildly toxic through inhalation and } \\
\text { ingestion; skin and eye irritant; emits } \\
\text { acrid smoke and irritating fumes when } \\
\text { heated to decomposition. }\end{array}$ & $\begin{array}{l}\text { Very dangerous fire hazard } \\
\text { when exposed to heat or } \\
\text { flame; can react with } \\
\text { oxidizing material. }\end{array}$ \\
\hline Zinc & $\begin{array}{l}\text { Human skin irritant; emits toxic fumes of } \\
\mathrm{ZnO} \text { when heated to decomposition. }\end{array}$ & $\begin{array}{l}\text { Dust form is flammable when } \\
\text { exposed to heat and flame; } \\
\text { dust form is explosive when } \\
\text { reacted with acids; may ignite } \\
\text { spontaneously in air when } \\
\text { dry; incompatible with } \\
\text { cadmium, chlorine, chromium } \\
\text { trioxide, nitric acid, selenium, } \\
\text { sulfur, water, sodium } \\
\text { hydroxide, nitrobenzene and } \\
\text { oxidants. }\end{array}$ \\
\hline
\end{tabular}


Of the chemicals identified in the wastes, those that are toxic or poisonous through any of the previously mentioned routes include acetone, arsenic, barium, barium chloride, bismuth, cadmium and cadmium-containing compounds, chromium, chromium trioxide, cresol, cyanide, hydrochloric acid, lead, mercury, methanol, methyl ethyl ketone, methylene chloride, nickel, nitric acid, nitrobenzene, selenium, Stoddard solvent, toluene, 1,1,1-trichloroethane, trichloroethylene, and xylene (Sax and Lewis, 1989).

Some chemicals such as acetone, chromium trioxide, hydrochloric acid, mercury, nitric acid, sodium potassium, xylene, and zinc are skin or eye irritants. Many of the chemicals are known or suspect human carcinogens. Known carcinogens include arsenic, asbestos, and chromium trioxide. Suspect carcinogens are cadmium, cadmium chloride, chromium, lead, and methylene chloride (Sax and Lewis, 1989).

Many chemicals emit toxic or irritating vapors or fumes either under ambient conditions, upon contact with other chemicals, or during heating. Chemicals that produce toxic fumes when heated to decomposition include cadmium and cadmium-containing compounds, chlorine-containing compounds, cyanide, lead, mercury, nitrogen-containing compounds, potassium, selenium, sodium, sodium potassium, sulfur-containing compounds, and zinc. Others produce acrid smoke or irritating fumes when heated to decomposition. These include arsenic, cresol, methanol, methyl ethyl ketone, Stoddard solvent, toluene, and xylene. Bismuth, cyanide, and sulfide can react with acid to emit toxic vapors. Cyanide and sulfide can also react with water or moisture to produce toxic vapors (Sax and Lewis, 1989).

\subsubsection{Safety Considerations}

Each chemical was analyzed for the following safety hazards: flammability, ignitability, and fire hazard; explosion hazard; and reactivity and incompatibility with other chemicals that will be used in the facility. The results of the analysis are described in this section. Table 1 presents a summary of these results.

Many chemicals in the waste streams are flammable under certain conditions or can ignite upon contact with other chemicals, and therefore are considered fire hazards. Flammability is defined in terms of flash point. In this study, a material with a flash point below $100^{\circ} \mathrm{F}$ is dangerously flammable; a material with a flash point between 100 and $200^{\circ} \mathrm{F}$ is moderately flammable; and a material with a flash point above $200^{\circ} \mathrm{F}$ has low flammability (combustible). Flammable materials should be stored near proper fire protection equipment. In addition, chemicals should not be stored near those chemicals with can cause it to ignite.

Acetone, potassium, sodium, and sodium potassium are inherently flammable; while zinc may ignite spontaneously in dry air. Other chemicals are flammahle when exposed to heat, flame, or oxidizing material. These include acetone, bismuth, cresol, cyanide, methanol, methyl ethyl ketone, nitrobenzene, Stoddard solvent, sulfides, toluene, trichloroethylene, xylene, and metal dusts. Chemicals that ignite upon contact with other chemicals include cadmium dust and nitric acid with metals; chromium in atmospheres of carbon dioxide; chromium trioxide on contact with methanol; tin dust and copper on contact with chlorine; and cyanide and sodium when exposed to heat and moisture (Sax and Lewis, 1989). 
Many chemicals identified in the candidate waste streams are explosive or may present explosion hazards under appropriate conditions. Acetone, chromium powder, and sodium potassium are inherently explosive. Chemicals that are explosive in the presence of heat or flame include methyl ethyl ketone and nitrobenzene; dust of arsenic, barium, cadmium, and zinc; and vapors of cresol,' methanol, methylene chloride, Stoddard solvent, and toluene (Sax and Lewis, 1989).

Certain chemicals react explosively with other chemicals to produce a sudden release of pressure, gas, or heat. Barium and sodium potassium undergo explosive reactions with water. Chromium is potentially explosive in atmospheres of carbon dioxide. Chromium trioxide reacts explosively with organic materials and solvents. Acids, nitrobenzene, and some halogenated hydrocarbons react explosively with potassium, sodium, and/or sodium potassium. Nitric acid forms explosive mixtures with metals and nitrobenzene and reacts explosively with hydrocarbons and sulfur dioxide (Sax and Lewis, 1989).

Some chemicals are safety hazards due to reactivity with other chemicals. Reactivity is defined as the tendency of a substance to undergo chemical reaction with the release of energy. Efforts should be made to store incompatible chemicals away from each other. Some chemicals react violently with water and therefore should not be stored in an area protected with a sprinkler system. The water-reactive chemicals identified in the candidate waste streams include barium, cyanide, potassium, sodium, sodium potassium, and zinc. Sodium is particularly dangerous in that it reacts exothermically with moisture of the body or tissue surfaces causing thermal or chemical burns (Sax and Lewis, 1989).

Sodium is one of the most reactive substances present in the candidate wastes. It reacts violently with water to form sodium hydroxide, which itself is very reactive and reacts violently with hydrochloric acid, halogenated hydrocarbons, and zinc. Sodium also reacts with oxidizing materials, such as chromium trioxide; halogens; acids, including hydrochloric and nitric acids; halogenated hydrocarbons, such as methylene chloride, 1,1,1-trichloroethane, and trichloroethylene; and under appropriate conditions air, moisture, carbon dioxide, hydrogen sulfide, selenium, and sulfur. Sodium potassium is also very reactive; it reacts violently with oxygen, water, halogens, oxidizers, and acids. Potassium alone is also reactive with selenium and some halogenated hydrocarbons (Sax and Lewis, 1989).

Other chemicals that react with oxidizing material include metals and organics. Selenium reacts violently with chromium trioxide, metals, nickel, nitric acid, oxygen, and zinc. Other substances that react with nitric acid include acetone, bismuth, cresol, cyanide, hydrogen sulfide, metals, methanol, and zinc. Other reactions include copper with hydrogen sulfide in air; mercury and methanol with metals; nickel with sulfur; and zinc with cadmium, chromium trioxide, sulfur and nitrobenzene. (Sax and Lewis, 1989). 


\section{DETAILED HEALTH AND SAFETY STUDY}

In the detailed health and safety study, criteria will be developed to analyze the health and safety risks of candidate waste streams and treatment technologies for the proposed facility. To develop these criteria, pertinent information regarding waste treatment facilities, applicable treatments, applicable wastes, human exposure, air quality, radiation, safety and dangers, monitoring requirements, and limits on any of the above, will be obtained from various sources. The applicable EG\&G Idaho, Inc. company and guidance manuals that will be used include the Industrial Hygiene Manual, Safety Manual, Radiation Control Manual, Emergency Preparedness Manual, Waste Management Compliance Manual and guidance for writing Safety Analysis Reports. Information will also be obtained from regulations that have been developed to protect human health and safety. These regulations include Occupational Safety and Health Administration regulations; State of Idaho air regulations; Environmental Protection Agency regulations, such as the Resource Conservation and Recovery Act, Clean Air Act, and Toxic Substances Control Act; and Department of Energy Orders. Other possible sources include reference books, journals, and personal commun iation with cognizant professionals.

Relevant information will be entered into a database, which will allow for ease in manipulating the data. The database will include the following material: targeted information; reference from which the information was obtained; waste or chemical associated with the information; treatment associated with the information; and the health and safety category which relates to the information. Other data may be added, if necessary.

An example of the database format is presented in Table 2. Column 1 lists the book, manual, or other source from which the information was obtained; column 2 specifies the pertinent information; column 3 lists the page number of the reference on which the information was found; column 4 indicates other references which may contain the same information; column 5 lists the chemical to which the information applies; column 6 lists the treatment to which the information applies; and columns 7 and 8 list health and safety categories under which the information falls. Each entry in the database will contain the targeted information, a reference, and a health and safety category. The entries may or may not have a chemical or a treatment associated with them. After all of the information is entered, the health and safety criteria will be developed from the health and safety categories listed in the database.

To evaluate potential waste streams and treatment technologies according to the health and safety criteria, the criteria will be formulated into two checklists--one for waste streams and one for treatments--that will be used to analyze the potential waste streams and treatments. The results of the study will be presented in a report discussing health and safety issues for the candidate waste streams and treatment technologies for the proposed Mixed and Low Level Waste Treatment Facility. 


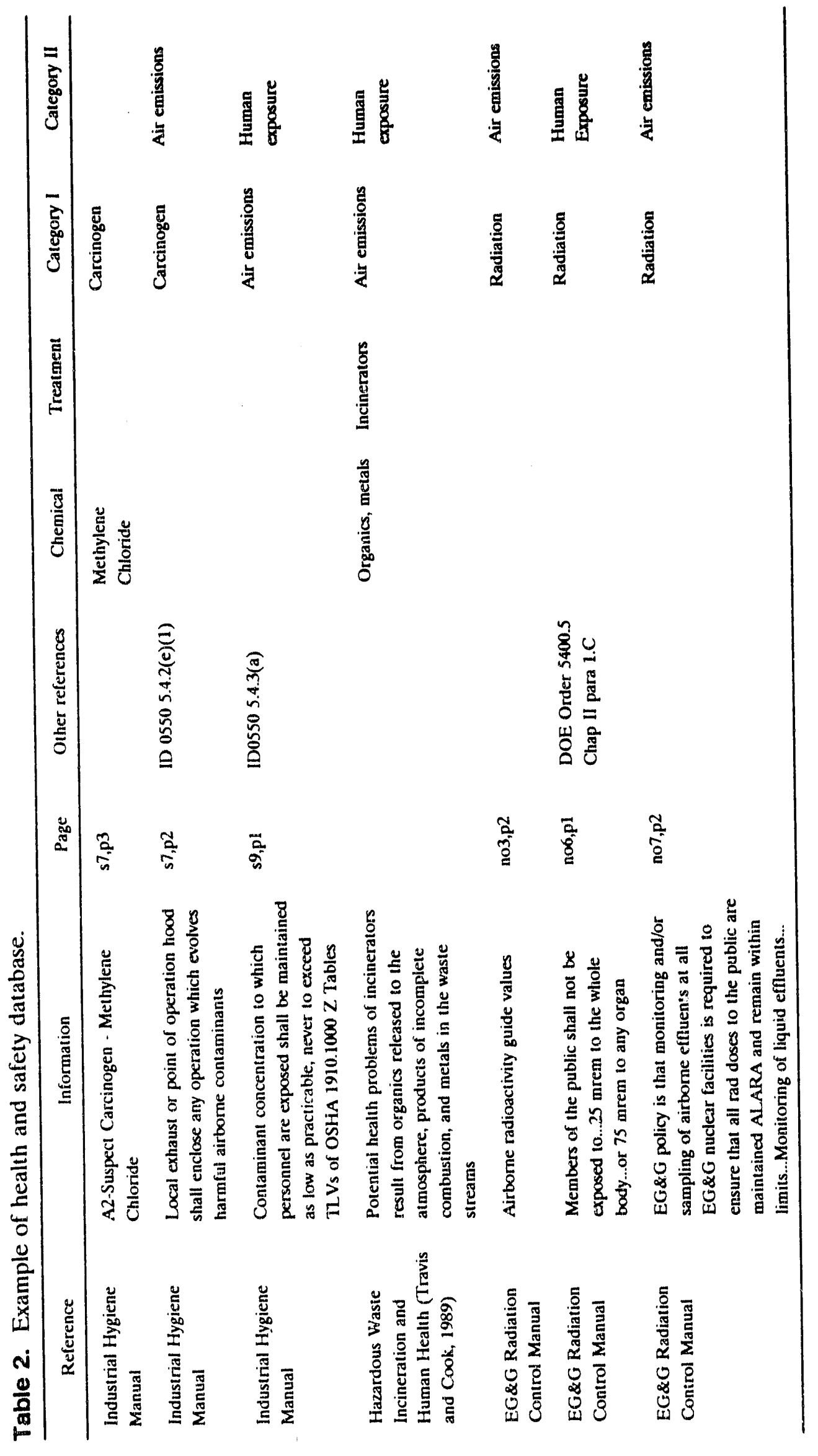




\section{REFERENCES}

Sax, N.I. and R.J. Lewis, Sr., 1989, Dangerous Properties of Industrial Materials, 7th ed., New York: Van Nostrand Reinhold.

Travis, C.C. and S.C. Cook, 1989, Hazardous Waste Incineration and Human Health, Boca Raton, Florida: CRC Press, Inc. 

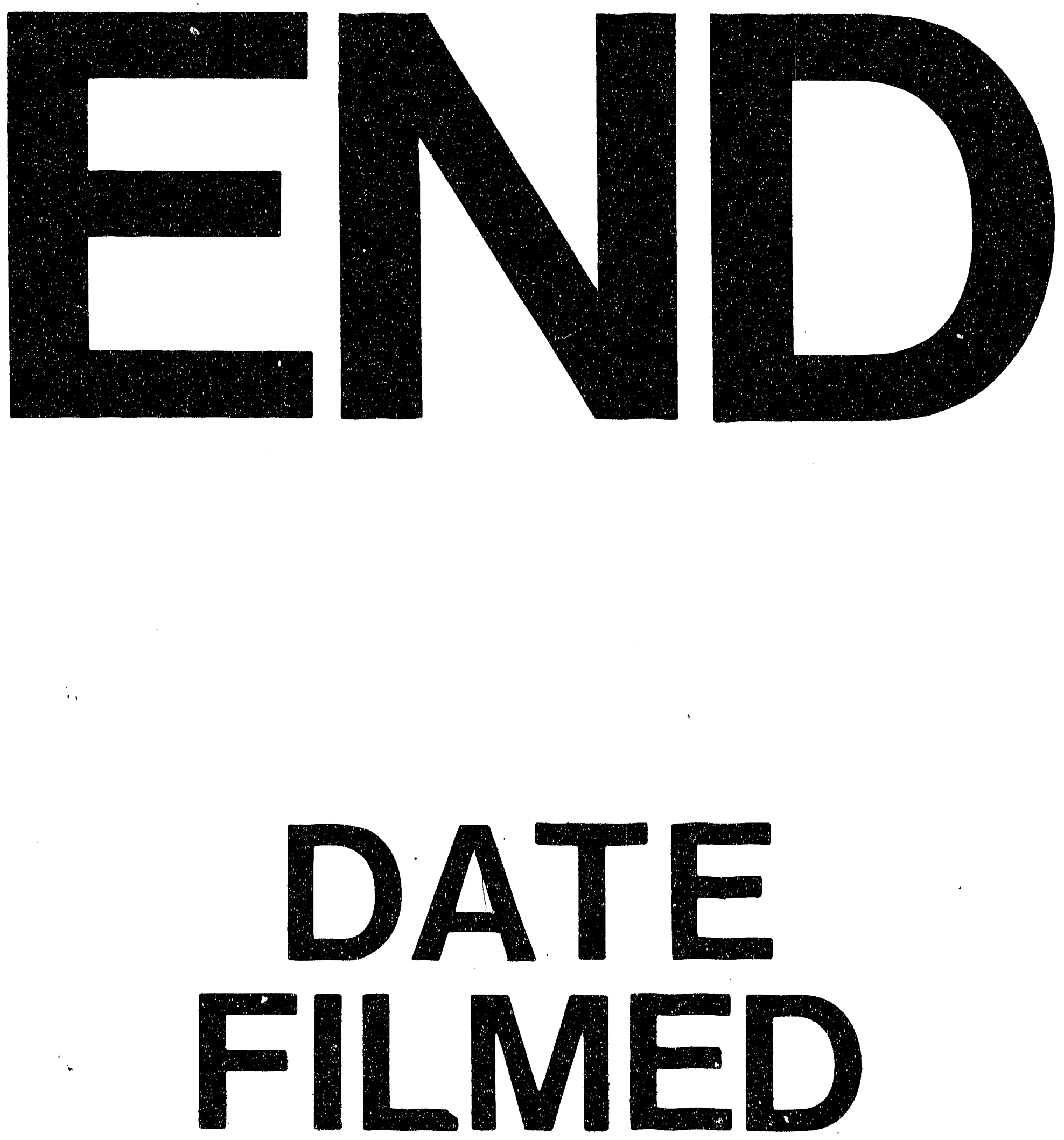

1

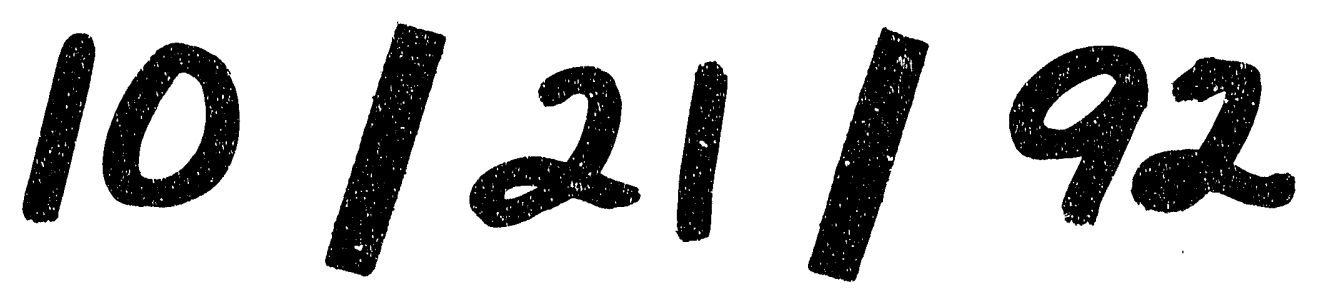

